\title{
WestVirginiaUniversity
}

THE RESEARCH REPOSITORY @ WVU

West Virginia Agricultural and Forestry Experiment

Davis College of Agriculture, Natural Resources

Station Bulletins

And Design

$1-1-1940$

\section{Cooperative purchasing of farm supplies in West Virginia}

Martin A. Abrahamsen

Follow this and additional works at: https://researchrepository.wvu.edu/ wv_agricultural_and_forestry_experiment_station_bulletins

\section{Digital Commons Citation}

Abrahamsen, Martin A., "Cooperative purchasing of farm supplies in West Virginia" (1940). West Virginia Agricultural and Forestry Experiment Station Bulletins. 297.

https://researchrepository.wvu.edu/wv_agricultural_and_forestry_experiment_station_bulletins/298 @ WVU. It has been accepted for inclusion in West Virginia Agricultural and Forestry Experiment Station Bulletins by an authorized administrator of The Research Repository @ WVU. For more information, please contact ian.harmon@mail.wvu.edu. 
West Virginia University Libraries

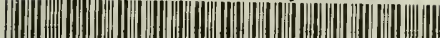

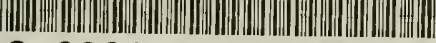

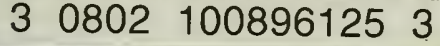





\section{Cooperative Purchasing of Farm Supplies in West Virginia}

by M. A. Abrahamsen

AGRICULTURAL EXPERIMENT STATION

COLLEGE OF AGRICULTURE, FORESTRY, AND HOME ECONOMICS WEST VIRGINIA UNIVERSITY

C. R. ORTON, Director MORGANTOWN 


\section{Note}

Since completion of this study, which deals primarily with the purchasing activities of the Cooperative Farm Services, that association has given attention to rather extensive plans for reorganization. It is planned eventually to establish all of the present branch warehouses of Cooperative Farm Services as incorporated associations, locally colltrolled and managed. This means changes with respect to policies of organization and operation. These contemplated changes will be indicated in the discussion of each section to which they apply. Where observations and descriptions apply to prevailing methods of operation they will be indicated as such.

It is believed, however, that the proposed reorganization of Cooperative Farm Services will necessitate no material change in the contents of this publication. Foremost among the reasons for this view are that (1) many of the problems considered and the recommendations offered will apply just as readily to locally controlled and managed cooperative establishments undertaking the distribution of farm supplies as they now do to the Cooperative Farm Services; (2) since it will take some time to effect complete reorganization all the problems indicated will continue to concern Cooperative Farm Services for some time to come; and (3) the presentation of past and present plans of operation should be of assistance to Cooperative Farm Services in acquainting management and patrons with the many and varied problems of operating a farm-supply business.

In certain parts of this publication the author has felt obligated to offer certain suggestions. It is not believed that these suggestions constitute the final answer to many of the problems of cooperative purchasing associations. It is hoped, however, that they may supplement the lines of thought and stimulate the interest of the boards of directors, managers, and patrons of these associations. The ultimate success of cooperative purchasing in West Virginia will depend to a large extent upon the degree to which leaders acquaint themselves with the problems of these associations and assume responsibility in working out solutions that are in accordance with sound cooperative principles. 


\section{CONTENTS}

The Nature and Extent of Cooperative Purchising $\ldots \ldots \ldots \ldots \ldots \ldots \ldots \ldots \ldots \ldots \ldots \ldots$

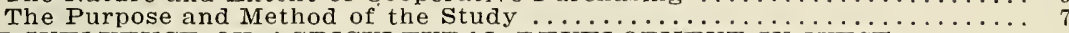

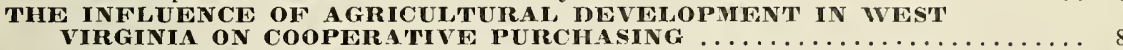

Expenditures for Feed and Fertilizer $\ldots \ldots \ldots \ldots \ldots \ldots \ldots \ldots \ldots \ldots \ldots \ldots \ldots \ldots \ldots$

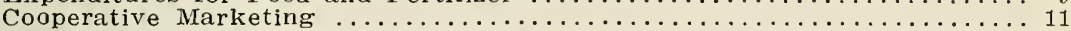

Relationship of General Agricultural Development to Cooperative Purchasing 1 ?

THE HISTORICAL DEVELOPMHNT OF COOPHIRATIVE RURCHASING

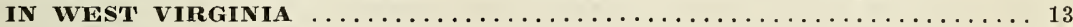

General Farm Organizations $\ldots \ldots \ldots \ldots \ldots \ldots \ldots \ldots \ldots \ldots \ldots \ldots \ldots \ldots \ldots \ldots \ldots \ldots \ldots 12$

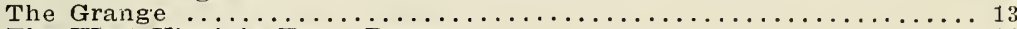

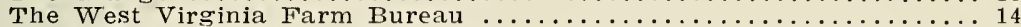

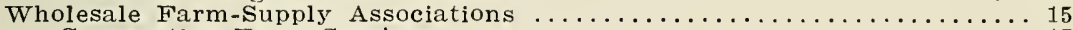

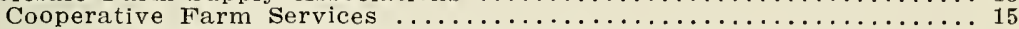

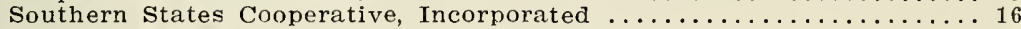

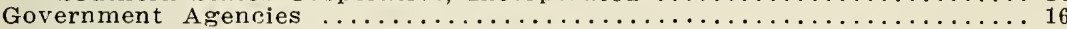

The College of Agriculture, Forestry, and Home Economics ......... 16

The West Virginia State Department of Agriculture .............

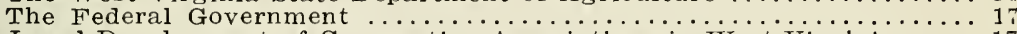

The Legal Development of Cooperative Associations in West Virginja .... 17

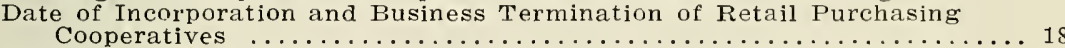

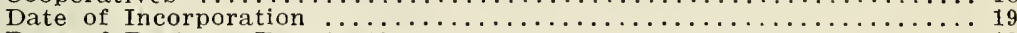

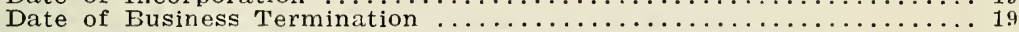

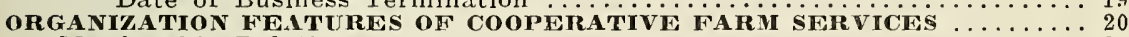

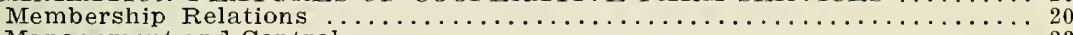

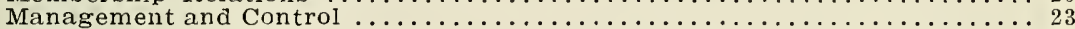

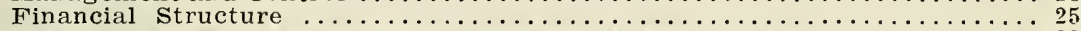

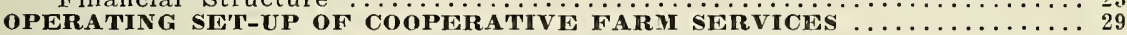

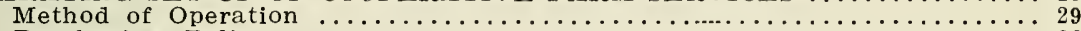

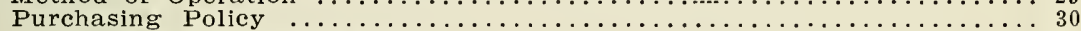

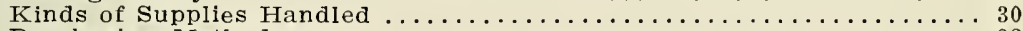

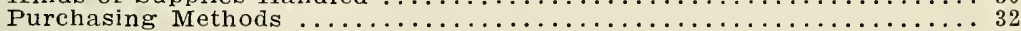

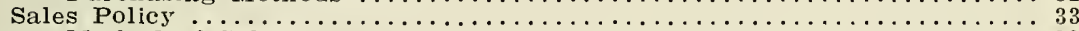

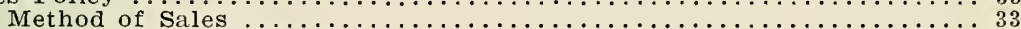

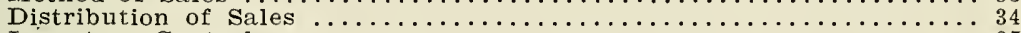

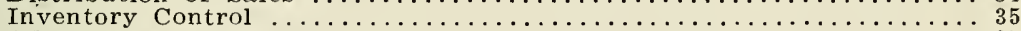

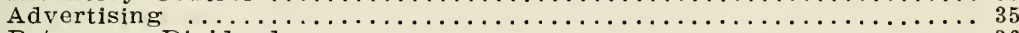

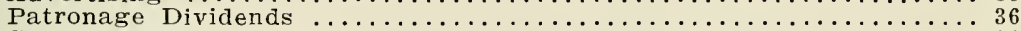

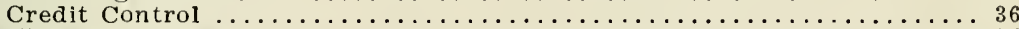

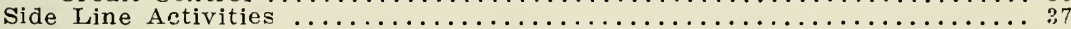

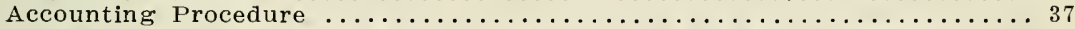

THE OPERATING AND FINANCIAL CONDITION ON THE COOPERATIVE FARM SERVICES

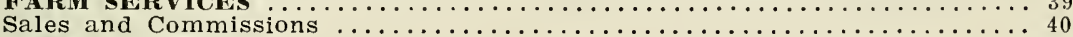

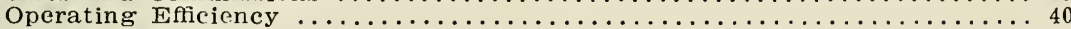

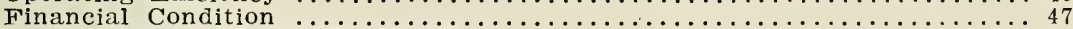

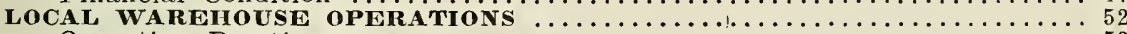

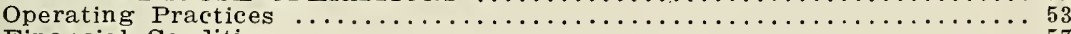

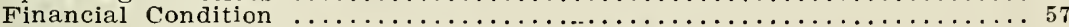

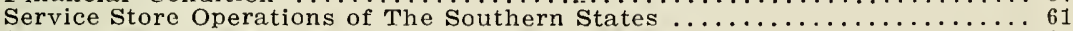

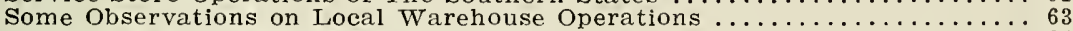

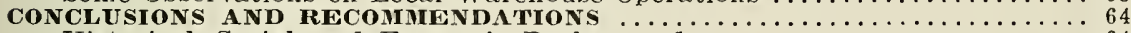

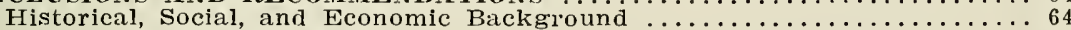

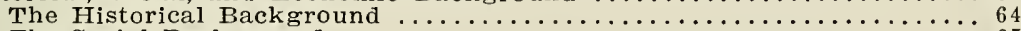

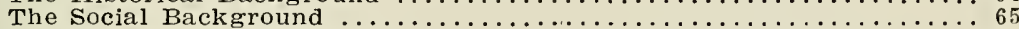

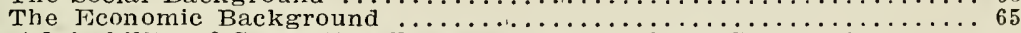

The Advisability of Separating Business Control of the Cooperative

Farm Services from the West Virginia Farm Bureau ............66

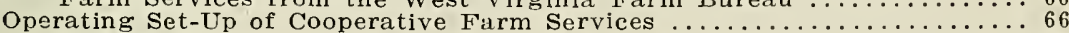

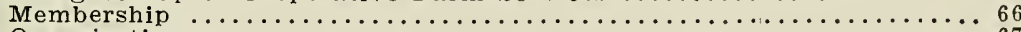

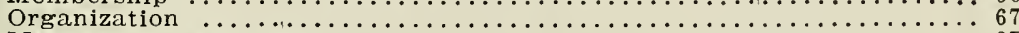

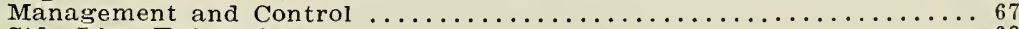

Side Line Enterprises $\ldots \ldots \ldots \ldots \ldots \ldots \ldots \ldots \ldots \ldots \ldots \ldots \ldots \ldots \ldots \ldots \ldots \ldots \ldots \ldots \ldots \ldots \ldots . \ldots \ldots$

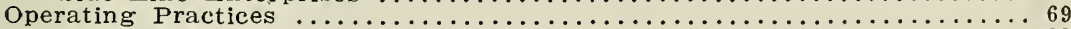

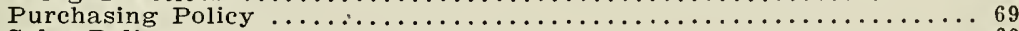

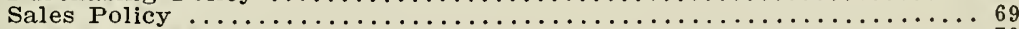

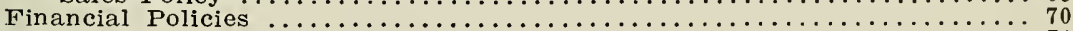

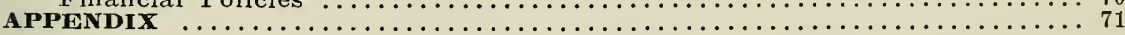




\section{COOPERATIVE PURCHASING OF FARM SUPPLIES IN WEST VIRGINIA*}

\section{INTRODUCTION}

Cooperative purchasing of farm supplies is a relatively new undertaking in West Virginia. The following seven developments constitute important steps in its growth in the state since 1916 :

1. Organization of unincorporated car-door agencies and informal farmers' buying clubs through the influence of such agencies as County Improvement Associations, County Farm Bureaus, and the West Virginia Farm Bureau between 1916 and 1922.

2. Passage of the first cooperative marketing act in 1921. This law provided for non-stock associations only and was followed in 1923 by the first law providing for the organization of farmers' cooperative associations with or without capital stock.

3. Incorporation of many of the previously organized local car-door agencies as county farm bureau warehouse associations between 1922 and 1926.

4. Organization of the West Virginia Farm Bureau Service Company by the West Virginia Farm Bureau in 1925. The purpose of this company was to function as a service and buying agency for the county Farm Bureau cooperative purchasing associations.

5. Reorganization in 1929 and 1930 of the majority of the county Farm Bureau purchasing associations so as to enable the.r operation as branch units by Cooperative Farm Services, which was the name assumed by the West Virginia Farm Bureau Service Company upon its reorganization in 1928 .

6. Entrance of Southern States Cooperative, Incorporated, into the farm supply business in the Eastern Panhandle of West Virginia in 1937 through the organization of two branch service stores and the supplying of numerous independent dealers with Southern States products.

7. Contemplated reorganization of Cooperative Farm Services in 1939 along federated lines by making provisions to work out means

*Acknowledgment is expressed to the BaItimore Bank for Cooperatives for assistance in the collection of data; to Mr. LoweIl Folsom, formerly an assistant in the Department of Agricultural Economics, West Virginia University, who served as fieldman in collecting data and information; to Mr. A. B. Post and Mr. C. D. Wysor, general managers respectively of Cooperative Farm Services and of Southern States Cooperative, Incorporated, for furnishing data and information for the associations with which they are affiliated. Appreciation for advice and assistance is also expressed to Dr. W. W. Armentrout, head of the Department of Agricultural Economics, West Virginia University, to Professor R. K. Froker, associate agricultural economist, University of Wisconsin, and to Joseph G. Knapp, principal agricultural economist of the Cooperative Division of the Farm Credit Administration, Washington, D. C.

${ }^{1}$ This publication is a revision of a thesis submitted to the Graduate School of the University of Wisconsin for the degree of Doctor of Philosophy. 
whereby the ownership and control of retail warehouses eventually will be assumed by patrons thorugh the establishment of local cooperative farm supply associations.

Further consideration is given these developments in the section which treats of the historical development of cooperative purchasing in the state (see page 13 ).

\section{The Nature and Extent of Cooperative Purchasing}

Four types of cooperative associations retail farm supplies in West Virginia. These are: (1) warehouse associations, which handle feed, reed, lime, fertilizer, building material, electrical equipment, limited amounts of household supplies, and miscellaneous items; (2) store associations, which combine groceries and dry-goods together with limited amounts of feed, seed, and similar products: (3) general supply associations, which include Future Farmer clubs handling feed, seed, and fertilizer for high-school agricultural projects, and county lime associations which grind and distribute lime for agricultural purposes; and (4) marlieting associations, which handle limited amounts of farm supplies as a side line for members.

T'ABTE 1-lietail sales of farm supplies as reported by 18 cooperative associations in West Virginia, 1936

\begin{tabular}{l|c|c|c}
\hline \hline \multicolumn{2}{c|}{ Associations } & \multicolumn{2}{c}{ Sales } \\
\cline { 3 - 4 } \multicolumn{1}{c}{ Type } & \multirow{2}{*}{ Number } & Amount & $\begin{array}{c}\text { Percentage of } \\
\text { total }\end{array}$ \\
\hline & & dollars & percent \\
Warehouse & $3^{1}$ & 627,975 & 85.5 \\
General supply & 8 & 19,766 & 1.7 \\
Store & 1 & 10,209 & 1.4 \\
Marketing & 6 & 76,775 & 100.0 \\
$\quad$ Total & 18 & 734,725 & 10.4 \\
\hline \hline
\end{tabular}

${ }^{1}$ Includes Cooperative Farm Services, which operates 14 branch warehouses and reports sales totaling $\$ 542,724$.

The extent of retail sales of farm supplies in 1936 is shown in Table 1. It will be observed that sales approximated three-fourths of a million dollars and that 85.5 percent of all sales were through cooperative warehouse associations, 10.4 percent through marketing cooperatives, and 4.1 percent through store and general supply associations. As used by Cooperative Farm Services, the term sales also includes farm products marketed as well as transfers of farm supplies between local warehouse units. Examination of the business records for 1937 indicates that these items comprised around 10 percent of the Association's business.

While detailed information is not available concerning the value of the various types of products handled by cooperative purchasing associations, estimates furnished by Cooperative Farm Services, which made 86 percent of all retail sales of cooperative warehouse associations in 1936, indicate that feeds comprised about one-half of total sales; fertilizer, one-fourth; and general products such as seed, hardware and fencing, electrical equipment, groceries, household supplies, and build- 
ing materials, the remaining one-fourth. About 60 percent of the supplies sold by marketing associations consisted of orchard supplies, the most important of which were fertilizer, spray material, and packing supplies. Feed, seed, and fertilizer constituted the greater amount of the remaining supplies handled by marketing associations.

In addition to retail sales, farm supplies are handled wholesale for two types of dealer agencies. These are: (1) informally organized county Farm Bureaus and (2) independent dealers handling products of either Cooperative Farm Services or Southern States: While data are not available, it is estimated by the Cooperative Farm Services that its wholesale business with these agencies, which in volume and in nature is reported to be approximately the same as that purchased for the Association's branch warehouses, amounts to between one-third and two-thirds of a million dollars annually. This business is carried on through Farm Bureaus in 18 counties and through one or more private dealers in each of 11 counties. In 5 of these counties, however, both Farm Bureaus and private dealers obtained supplies wholesale through the Cooperative Farm Services.

Cooperative Farm Scrvices is the only large-scale purchasing association located within the state. Through its warehouse division, which operates its $14^{2}$ branch warehouses, it engages in the retail distribution of farm supplies, while through its purchasing division supplies are purchased wholesale for its warehouse division, for county Farm Bureaus, and for independent dealer's.

The wholesale department of Southern States, with headquarters at Richmond, Virginia, together with Cooperative Farm Services and with the State Farm Bureau Warehouse Association of Pennsylvania, operates a fertilizer plant at Baltimore, Maryland. Southern States also furnishes general farm supplies for affiliated private dealers in 17 counties in the eastern part of the state. The service-store division of the association operates the two branch warehouses in the state. For the fiscal year ending June 30, 1938, farm supply sales by the two Southern States warehouses operating in West Virginia were reported at $\$ 87,576$; wholesale purchases by affiliated dealers were estimated at $\$ 85,000$.

The location of the various types of retail and wholesale agencies distributing farm supplies in West Virginia is shown in Figure 1. Distributing agencres purchasing through wholesale associations are shown by counties only. No further distinction is possible because these agencies are constantly changing and frequently vary for the different kinds of supplies handled.

\section{The Purpose and Method of the Study}

Many of the problems confronting cooperative purchasing associations in West Virginia have remained unsolved. After 15 to 20 years of experience, however, associations are in a position to furnish valuable information as to the success or failure of various organization policies pursued and business practices followed, as well as to supply data for the measurement of operating efficiency. To this end, data and in-

'Since completion of this study the number of active branch warehouses has been reduced to 13 . 


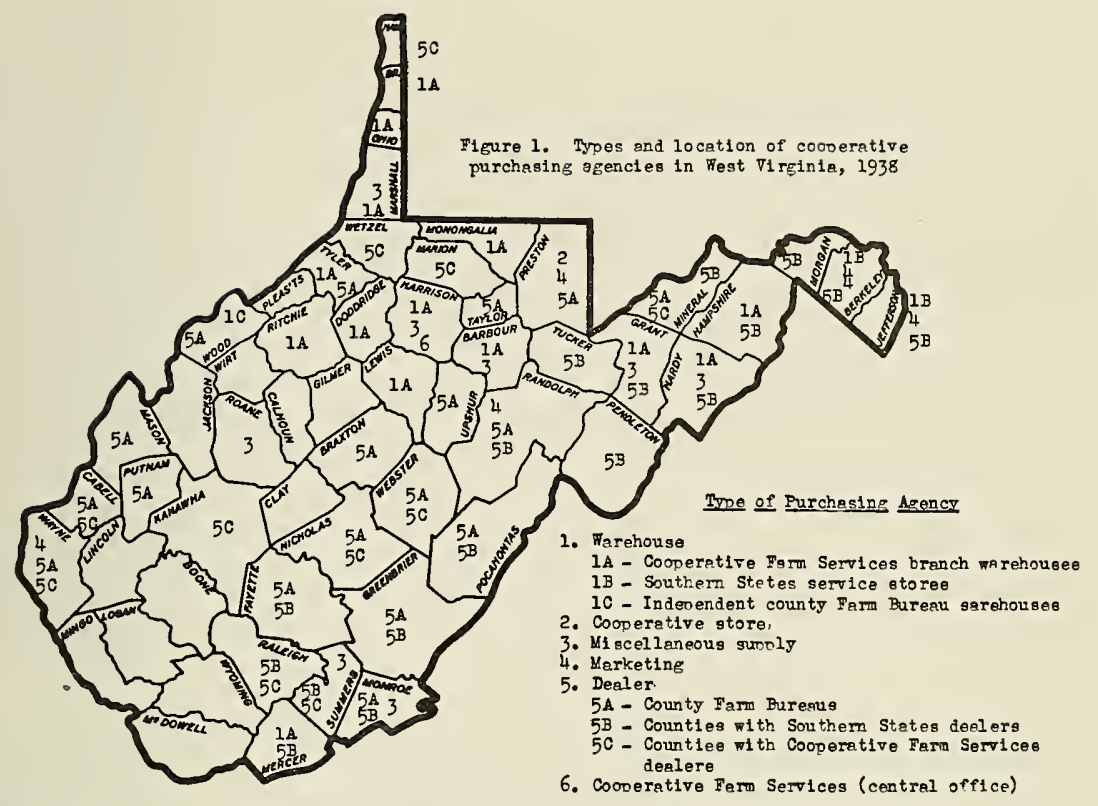

formation were obtained relative to: (1) the historical development of purchasing associations; (2) agricultural and general economic conditions influencing the development of and the possibilities in cooperative purchasing; (3) organization features giving special consideration to problems of membership, management and control, and financial structure; (4) operating set-up paying particular attention to facilities, personnel, purchasing policy and methods, sales policy, side line activities, and accounting and auditing procedure; and (5) operating efficiency as indicated by available balance sheets and operating statements. The purpose of the present study is to relate the information obtained to the specific problems of cooperative purchasing associations, in order that an appraisal of present organization features and operating methods may be helpful in establishing sound and workable policies as a guide for effective and efficient business practices.

Examination of the organization, operation, and performance of a farm-supply association such as Cooperative Farm Services also should be helpful in evaluating the practicability of conformance with what have been recognized as the generally accepted principles of cooperative endeavor. After nearly 100 years of experimentation and testing, efficiency, distribution, and business control have become the three guiding economic principles of agricultural cooperative associations. ${ }^{3}$ In suggesting economy, service, and quality as the major objectives of farmers' purchasing associations, Knapp gives special attention to the principle of efficiency as the economic basis of operation. ${ }^{4}$

${ }^{3}$ E. G. Nourse, “The Economic Philosophy of Cooperative Marketing." American Economic Reviev, vol. XII, p. 578.

${ }^{4} \mathrm{Joseph}$ G. Knapp, "Cooperative Purchasing of Farm Supplies," Cooperative Division, Farm Credit Administration, Bul. No. 1, p. 6, 1935. 
The actual experience of cooperative purchasing associations has demonstrated the soundness of operation in accordance with these principles. Efficient operation has become closely associated with such practices as: (1) careful attention to financial policies; (2) constant and continual checks on purchasing, sales, and operating policies; (3) establishment of adequate accounting systems; and (4) limitation of business primarily to agricultural items. The payment of limited interest rates on capital invested in an association and the distribution of savings to patrons in proportion to the business done with it is in accordance with approved cooperative practice. Finally, with respect to business control, cooperative associations have found that almost invariably most satisfactory results are obtained when patronage, ownership, and management of an organization are associated in the same individuals.

In cooperation with the Baltimore Bank for Cooperatives, every active farm-supply association in the state was visited in the spring of 1937. Records were obtained concerning methods of organization; nature and extent of business operations; and policies and problems of management, purchases and sales, and financing.

Examination of the data obtainable and consideration of the types of purchasing associations operating in the state indicate that the warehouse associations were not only the most important but also the only establishments for which reasonably complete and usable data were available. Consequently this study, with the exception of giving consideration to the recent expansion of Southern States supply agencies operating within the state, will deal primarily with investigation and appraisal of the operations of Cooperative Farm Services.

\section{THE INFLUENCE OF AGRICULTURAL DEVELOPMENT IN WEST VIRGINIA ON COOPERATIVE PURCHASING}

It is difficult to appraise accurately the relationship to, and the influence of, general agricultural development in West Virginia on cooperative purchasing. It is believed, however, that brief consideration of such factors as types of farming, sources of gross and cash farm income, and land use, together with consideration of expenditures for farm supplies, as well as examination of the development of cooperative? marketing will be helpful in furnishing a background for evaluating the possibilities and the limitations of cooperative purchasing in the state. Careful appraisal of general agricultural conditions should also assist cooperative leaders in influencing the growth and direction of farmsupply purchasing along fundamentally sound lines.

To an appreciable extent, agricultural development in the state is predetermined by physical and climatic conditions. The distribution of farm supplies through cooperative agencies, to be effective, must be adjusted accordingly. Frequently greater differences in agricultural practices exist a few miles up a mountain road than may be found 50 or 100 miles up a river valley. Large corporation orchard farms of 300 acres or more often require annual expenditures of $\$ 5,000$ or more for supplies. 
In contrast many of the numerous, small, self-sufficient hillside farms have no outlay for supplies, and as a group their supply expenditures have averaged considerably less than $\$ 100$ a year. Purchases of supplies on livestock, general, self-sufficient, and part-time farms are not only less, but also are appreciably different from those on dairy, grain, fruit, and truck farms.

Further evidence of the status of agricultural development in the state is found in the types of farming engaged in, the sources of gross and cash farm income, and the prevailing land use. ${ }^{5}$ In spite of wide variation existing in the types of farming, about two-thirds of all farms are classified as self-sufficing or part-time, and the resulting low incomes, combined with small holdings, definitely mean limited expenditure even for the more important farm supplies. Between two-thirds and threefourths of both gross and cash farm income is from livestock and livestock products. Furthermore, it is significant that only three-fifths of all land in the state is in farms, that only one-fifth of farm land is in crops, and that corn and hay normally occupy three-fifths of all crop land.

\section{Expenditures for Feed and Fertilizer}

Since West Virginia is predominantly a livestock state, the purchase of feed for dairy and beef cattle and the use of seed and fertilizer for the production of feed are important items of farm expense. As previously indicated, about three-fourths of all purchases through cooperative farm supply associations in West Virginia are for these items.

TABLE 2-Number and percentage of total farms using feed and fertilizer, and average expenditures per farm on farms using these supplies in West Tirginia, classified according to type, 19291

\begin{tabular}{|c|c|c|c|c|c|c|c|}
\hline \multirow{3}{*}{ Type } & \multirow{3}{*}{$\begin{array}{c}\text { Total } \\
\text { Farms }\end{array}$} & \multicolumn{4}{|c|}{ Farms } & \multirow{2}{*}{\multicolumn{2}{|c|}{$\begin{array}{c}\text { Average } \\
\text { expenditure ner } \\
\text { farn using } \\
\text { purchased: }\end{array}$}} \\
\hline & & \multicolumn{2}{|c|}{ Using purchased: } & \multicolumn{2}{|c|}{$\begin{array}{l}\text { Percentage of } \\
\text { total using } \\
\text { purchased: }\end{array}$} & & \\
\hline & & Feed & $\begin{array}{c}\text { Fertil- } \\
\text { izer }\end{array}$ & Feed & $\begin{array}{c}\text { Fertil- } \\
\text { izer }\end{array}$ & Feed & $\begin{array}{c}\text { Fertil- } \\
\text { izer }\end{array}$ \\
\hline & number & number & number & percent & percent & dollars & doliars \\
\hline Self-sufficing & 32,622 & 15,782 & 9,504 & 48 & 29 & 62 & 22 \\
\hline $\begin{array}{l}\text { unclassified } \\
\text { General } \\
\text { Animal specialty } \\
\text { Dairy } \\
\text { Poultry } \\
\text { Stock ranch } \\
\text { Crop specialty } \\
\text { Fruit } \\
\text { Cash grain } \\
\text { Truck }\end{array}$ & $\begin{array}{r}19,111 \\
16,696 \\
5,116 \\
2,822 \\
1,685 \\
1,473 \\
1,445 \\
962 \\
458 \\
251\end{array}$ & $\begin{array}{r}9,343 \\
10,551 \\
3,148 \\
2,422 \\
1,258 \\
995 \\
479 \\
615 \\
194 \\
155\end{array}$ & $\begin{array}{r}4,382 \\
8,932 \\
2,964 \\
1,450 \\
635 \\
812 \\
591 \\
650 \\
275 \\
125\end{array}$ & $\begin{array}{l}49 \\
63 \\
62 \\
86 \\
75 \\
68 \\
33 \\
64 \\
42 \\
62\end{array}$ & $\begin{array}{l}23 \\
54 \\
58 \\
51 \\
38 \\
55 \\
41 \\
68 \\
60 \\
50\end{array}$ & $\begin{array}{r}98 \\
102 \\
120 \\
626 \\
376 \\
159 \\
76 \\
166 \\
95 \\
176\end{array}$ & $\begin{array}{r}26 \\
40 \\
50 \\
58 \\
35 \\
53 \\
51 \\
172 \\
105 \\
82\end{array}$ \\
\hline Total & 82,641 & 44,942 & 30,320 & . & .. & $\cdots$ & ... \\
\hline Average & $\ldots \ldots$ & $\ldots \ldots$ & $\ldots \ldots$ & 54 & 37 & 127 & 38 \\
\hline
\end{tabular}

${ }^{1}$ Compiled from the Fifteenth Census of the United States, 1930. Agriculture, vol. III, part 2.

${ }^{5}$ For a detailed consideration of types of farming in West Virginia see W. Va. Agricultural Experiment Station Bul. 292, "Types of Farming in West Virginia." For sources of gross and cash farm income see "West Virginia Agricultural Statistics." Bul. (N.S.) 1, p. 2, West Virginia Crop and Livestock Reporting Service, Charleston, W. Va. 
Some indication of the extent of feed and fertilizer purchases by various types of farms in the state in 1929 is shown in Table 2, which gives the number and percentage of farmers buying feed and the average expenditure for feed per farm. The proportion of dairy and poultry farms purchasing feed was around 60 percent higher than the average. The amount purchased on these farms exceded the state average by around five times for dairy farms and three times for poultry farms. Reference to Figure 2 shows that it is the dairy and poultry sections of the Eastern Panhandle (Morgan, Berkeley, and Jefferson Counties) and in the general farming areas of the Greenbrier, Kanawha, Monongahela, and Ohio River valleys where the expenditure for feed is greatest. On the basis of reported expenditures for feed and the amount of the cooperative farm supply business devoted to this item, indications are that roughly 10 percent of farm expenditures for feed are made through cooperative associations.

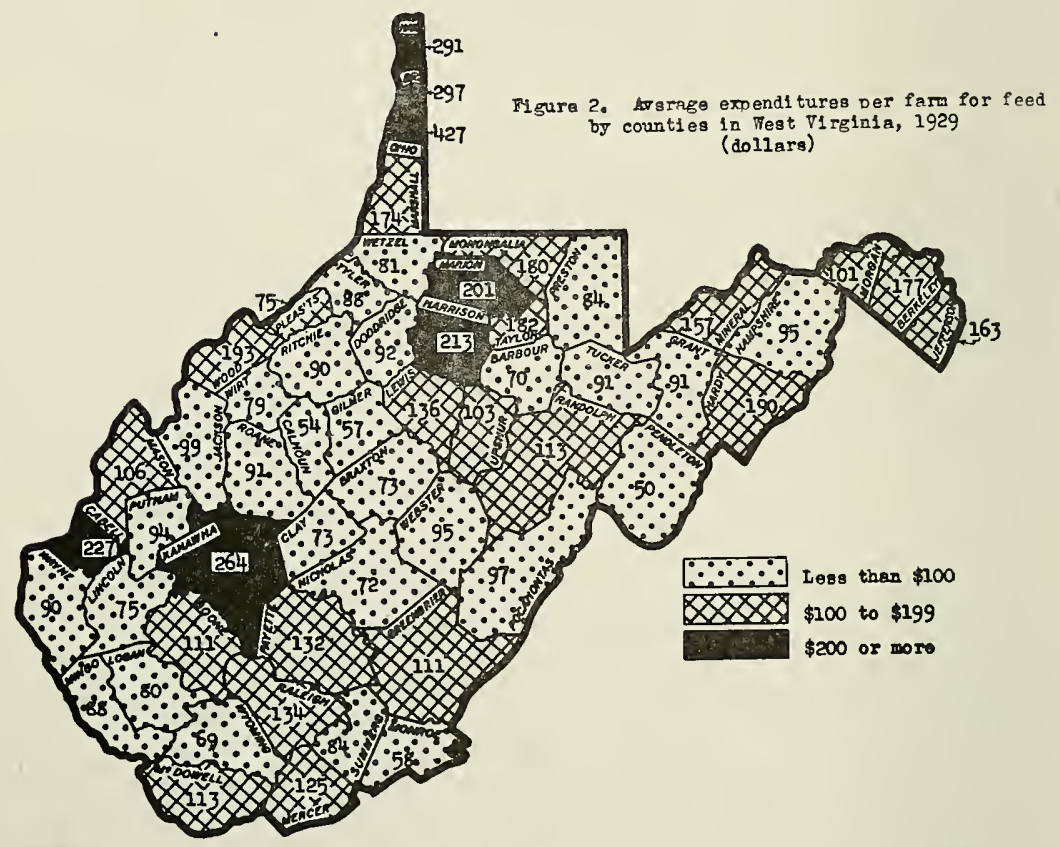

With respect to expenditures for fertilizer the data presented in Table 2 indicate that the average ontlay for fertilizer on all farms was $\$ 38$ in 1929. On truck, fruit, and cash-grain farms the amount of fertilizer purchased was two to four times the average for the state. This is substantiated further upon examination of Figure 3, which indicates that the fruit and grain sections of the Eastern Panhandle, the potato and cash-grain counties of the Eastern Appalachian mountain region, and the cash-crop sections of the Ohio River Valley use the greatest amount of fertilizer per farm. As was true with respect to feed, self-sufficing and part-time farms were also below the average for the state in both 
the percentage of farmers using fertilizer and in the average expenditures for fertilizer per farm. As closely as can be determined, not over 10 percent of the fertilizer purchased in the state moves through cooperative associations.

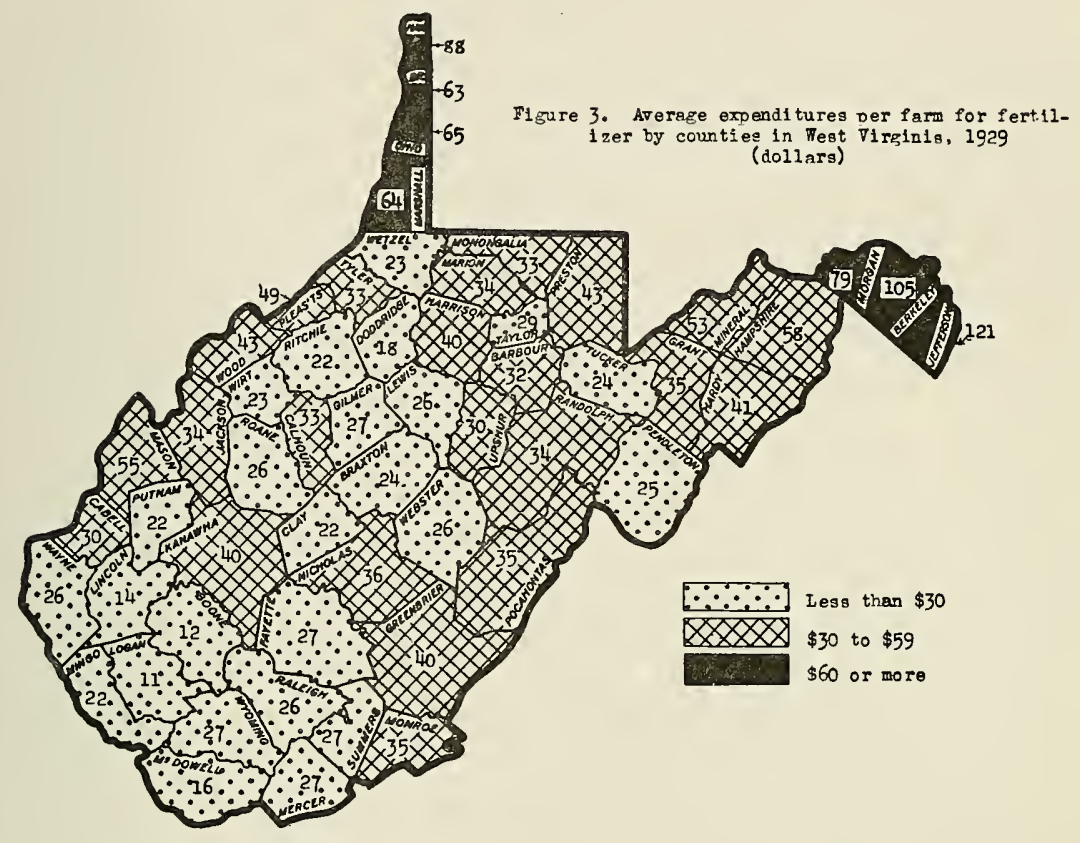

\section{Cooperative Marketing}

Two cooperative marketing associations operate in West Virginia on a state-wide basis. These are the West Virginia Livestock Marketing Association and the West Virginia Wool Marketing Association. The Wool Marketing Association, although subsequently reorganized, first started operations in 1920. The Livestock Association began business ir. 1923. In addition many dairy farmer's are members of the Dairymen's Cooperative Sales Association of Pittsburgh, Pa., and the Inter-State Producers Cooperative Association of Philadelphia, Pa.-both bargaining associations. A few additional local cooperative associations market dairy products, fruit, and timber.

The Farm Credit Administration reports that sales through farmer's cooperative marketing associations in . West Virginia totaled $\$ 2,613,000$ in 1936. This includes the following commodities: dairy products, $\$ 1,135,000$; livestock, $\$ 976,000$; wool, $\$ 115,000$; fruit and vegetables, $\$ 313,000$; and miscellaneous products, $\$ 74,000 .^{6}$ When compared with

6“A Statistical Handbook of Farmers' Cooperatives." Bul. 26, Cooperative Division, Farm Credit Administration, 1938 , p. 148. 
cash income, these figures indicate that from 6 to 8 percent of cash farm sales were made through cooperative associations.

\section{Relationship of General Agricultural Development to Cooperative Purchasing}

As indicated previously, gencral agricultural development as it relates to the present status and future possibilities of cooperative purchasing in West Virginia is difficult to measure and appraise. It does serve, however, to suggest that the following factors are important.

1. Both the nature and the extent of cooperative purchasing have definite limitations. Many farmers on self-sufficing farms make little or no appreciable expenditure for supplies, while many of those purchasing various supplies are poor credit risks. The proportion of bad debts among such patrons would likely be high. The forces of habit and custom also have a strong influence on many farmers, and they are often content to purchase supplies as they always have-from the merchant who buys their products-without giving careful consideration to the services performed, the quality of goods offered, or the prices charged.

2. The fact that purchases are small serves to make farmers less conscious of the advantages of purchasing supplies cooperatively. It is easier to purchase a sack of feed or fertilizer from the same merchant who handles groceries and dry goods than it is to go across the street to a farm-supply establishment.

3. The cost of merchandizing is high when sales are small and varied. The time and effort involved in selling one bag of feed or fertilizer is proportionally greater than that involved when one ton is sold.

4. The heterogeneity of farming and farm operations within a trading area necessitates relatively high inventories of many products, thereby increasing the cost of selling. This circumstance naturally results in a wide variety of interests and often serves to limit effective cooperative endeavor.

5. The large proportion of agricultural income from livestock and livestock products indicates a more stable basis for cooperative purchasing than exists in many of the cash-crop sections of the country. Regular income from livestock and livestock products usually means more cash for the purchase of farm supplies, a more uniform demand for supplies, and less dependence upon the eredit-merchant system.

6. Considerable emphasis has recently been placed upon soil conservation and pasture improvement in the state. To the extent that such emphasis is well directed, farmers gain valuable experience in working together, the demand for lime and fertilizer to carry out such programs will increase, and any resulting increase in farm income would be used in part for the purchase of additional farm supplies. ${ }^{7}$

'To date the Agricultural Conservation Program in West Virginia has had the effect of decreasing the direct purchasing of fertilizer and lime. Both the 1938 and 1939 programs include provisions for furnishing fertilizer in lieu of payment. Of the 49,000 farmers participating in the agricultural conservation program in 1939 , some 21,000 were furn ished 16,489 tons off 45 percent superphosphate direct from the TVA plants. Lime to the extent of 49,000 tons was also furnished on this basis to almost 7,000 farmers in 25 counties during 1939. It is estimated that between one-third and one-half million dollars of fertilizer and lime was furnished in lieu of payments in 1939. 
7. While intangible, the benefits to cooperative purchasing which result from such factors as (1) definite evidences of growth in cooperative marketing endeavor, and (2) the breakdown of provincialism in formerly isolated communities with the resulting encouragement given to new ideas, are contributing to an increased interest in and understanding of cooperative purchasing by farmers.

These seven factor's secm to indicate that if an appreciable increase in cooperative purchasing is to take place, it will have to come in part throngh (a) changes in general agricultural practices and in types of farming, which will require additional farm supplies suitable for cooperative distribution; and in part through (b) the establishment of effective business policies on the part of cooperative purchasing associations with respect to service, quality, and efficiency, to the end that patrons find it to their advantage to secure supplies from cooperative associations rather than from other farm-supply agencies.

\section{THE HISTORICAL. DEVELOPMENT OF COOPERATIVE PURCHASING IN WEST VIRGINIA}

The development of cooperative purchasing in West Virginia is largely attributable to: (1) support and encouragement of general farm organizations, particularly the Grange and the Farm Bureau, which have sponsored cooperative purchasing along with general agricultural programs; (2) organization of combination wholesale and retail farmsupply associations, such as Cooperative Farm Services and Southern States Cooperative, Inc.; (3) aid and assistance of governmental agencies; and (4) development of cooperative legislation.

\section{General Farm Organizations}

The Grange. The first organized attempt to assist West Virginia farmers through cooperative purchasing was undertaken by the Grange. The first local Grange in West Virginia was organized June 21, 1873, at Summit Point, Jefferson county. ${ }^{8}$ By 1877 there were 378 local granges with a membership reported at approximately 10,000 . That the movement was sporadic is indicated by the fact that in 1896 the number of local granges had decreased to 12 .

Summing up the cooperative purchasing activities of the Grange. T. C. Atkeson, Master of the State Grange from 1896 to 1922 and first dean of the West Virginia College of Agriculture, made the following statement in 1914:

"In early years the Grange established many cooperative stores in West Virginia, built woolen mills, wool warehouses, and engaged in other enterprises of similar character. Then a period of reactions came and most of these enterprises were closed out and some of them suffered tremendous losses. For the last 20 years the cooperative efforts of the Grange have been given to fire insurance, buying fertilizer, nursery stock, machinery, and general farm supplies."9

8Vest Virginia Bureau Farmer, June, 1914, Charleston, W. Va.

"Forrest W. Stemple, "The West Virginia Farmer and Grange Advocate," June, 1914, p. 2, Morgantown, W. Va. 
Although the Grange ceased to take active part in the promotion of cooperative organizations after 1890, it did, through informal farmers' buying clubs, farm institutes, and social activities, keep alive an interest in cooperative endeavor. While the West Virginia State Grange still maintains a state organization, leadership in formulating state agricultural policy has been assumed by the West Virginia Farm Bureau.

The West Virginia Farm Bureau. The West Virginia Farm Burean has taken an active part in recent years in fostering cooperative marketing and purchasing associations. During its first years of operation, local farm bureaus frequently purchased such farm supplies as flour, feed, fertilizer, salt, and lime through informal buying groups and through unincorporated car-door associations. Orders were pooled through the State Farm Bureau, which as early as 1922 acted as a purchasing agency in securing farm supplies. Arrangements were sometimes entered into with nearby state Farm Bureau federations to pool purchases for feed, fertilizer, and seed.

A number of conditions were responsible for the decline in importance of the car-door associations. Many were organized in response to special appeals rather than to economic necessity. In other instances questionable business practices led to their decline. More important. however, was the improvement of roads with its resulting relocation of trading centers and its facilitation of trucking.

Farmers also frequently experienced considerable difficulty in managing and financing such loosely organized associations as well as in adjusting operations to meet varied and changing needs. In many instances, as the demand for farm supplies expanded to the point where farmers were willing to pay additional costs in order to secure more complete service without unnecessary delay, they became acquainted with the possibilities of cooperative endeavor, and the natural outgrowth in the more extensive farming regions was the organization of local warehouse associations. This step was taken by many county Farm Bureaus between 1922 and 1926.

Since the cooperative law providing for stock associations was not passed until 1923, many of the early warehouses were incorporated under general corporation laws. The first warehouse to be incorporated under cooperative law was the Ohio County Farmers Cooperative (Roney's Point), incorporated May 15, 1923. While offering greater opportunities for service, such associations also required greater ability on the part of the members in shouldering responsibilities and in performing dutiesfunctions which in many instances they were ill prepared to assume.

Typical of the many difficult problems encountered in the organization and operation of early farm-supply associations and illustrative of the way in which these problems were met, as well as indicative of the type of business done by a local Farm Bureau association, is the following account of the activities of the Hardy County Farm Bureau Warehouse as reported in $1923:^{10}$

${ }^{10}$ Vest Virginia Farm Bureatu News, Aug. 1923, p. 3. 
"During the first year of the Bureau's existence nothing but commercial fertilizer was purchased, 236 tons being handled.

"During the summer of the next year, which was 1918 , the erection of a storage house or warehouse was talked about and on February 1, 1919, a committee was appointed to collect funds, buy a lot, and erect a building. A lot was purchased for $\$ 700$ which sum of money was borrowed on a note signed by three members of the Bureau.

"The money ito erect the warehouse was derived from the sale of stock at $\$ 10.00$ per share, no one being permitted to secure more than five shares. Thirty-three men subscribed the necessary money to erect the building. ...

"In 1920, the Board of Directors had a note for $\$ 5,000.00$ drawn up and signed by a number of Bureau members. This note was taken to the bank and used as collateral upon which to borrow money for conducting the business which has since increased to such an extent that the note was raised to $\$ 8,000.00$ this pasit year. It also became necessary to rent additional warehouse space.

"Before the warehouse was built, only acid phosphate was handled, but at the present time the warehouse handles fertilizer, salt, giant cement, plaster, all kinds of seed, lubricating oil, kerosene, sugar, lime, farm fence, farm implements, binder twine, wool twine, log chains, carbide, plaster board, tankage, meat scrap, cottonseed meal, oyster shell, and spray materials. ..."

\section{Wholesale Farm-Supply Associations}

Cooperative Farm Scrvices. In common with the experience of many other state Farm Bureau federations, the West Virginia Farm Bureau found it expedient to set up an association separate and distinct from the general farm organization to handle farm supplies. As early as 1922, a warehouse was rented. The primary purpose was to furnish storage for wool, although the Bureau reported that "other business such as the handling of feed, seed, fertilizer, fencing, roofing, paints, incubators, farm machinery, etc. is a project of the near future." Use of the warehouse was contingent upon membership in the Farm Bureau federation. To meet the growing needs of the local associations for furnishing supplies on a wholesale basis, the West Virginia Farm Bureau organized the West Virginia Farm Bureau Service Company in 1925.

While some of the local warehouses were relatively successful during the first years of operation and frequently did an annual business of over $\$ 100,000$, the unfavorable economic conditions following 1929 found many of the associations in dire financial circumstances. Poorly-trained managers as well as disinterested boards of directors often had sanctioned lax credit policies. Slow-moving, high-cost inventories were also built up. In most instances associations failed to operate in accordance with approved cooperative principles. 
After taking over the operation of local branch warehouses, Cooperative Farm Services became associated with all phases of cooperative purchasing in the state. In addition to its own warehouse division it sold supplies to a few independently operated Farm Bureau warehouses and to local Farm Bureaus, which because of limited volume of business secured supplies on a car-door basis or by truck; and not unlike the early efforts of the Grange, arrangements were made in certain localities with independent dealers to handle supplies for Farm Bureau members. This practice was especially common in regions of limited agricultural development.

Southern States Cooperative, Incorporated. In 1937 Southern States extended its business into the eastern and southern parts of West Virginia. Branch service stores were opened at Martinsburg and Charles Town. In addition, agreements were entered into with approximately 25 private dealer agencies to operate under conditions and at margins required by Southern States.

\section{Government Agencies}

Such agencies as the College of Agriculture, Forestry, and Home Economies of West Virginia University, the West Virginia State Department of Agriculture, and the Federal Government have also influenced the development of cooperative associations in the state. In those instances, however, in which state agencies have undertaken to furnish assistance, it has been primarily along promotional lines rather than through a study of the need for or the activities of cooperative associations.

The College of Agriculture, Forestry, and Home Economics. The limited research carried on with respect to cooperative associations in the state has meant that the Agricultural Experiment Station has not been able to guide effectively the efforts of the Extension staff in its attempts to aid cooperative associations. It is believed that in too many instances cooperatives have been promoted without giving careful attention to the needs of farmers. In other instances too much responsibility has been assumed by Extension specialists and county agents in the organization, operation, and management of cooperative associations. Consequently many cooperatives have existed as "top-down" associations, with no efforts made or inclination expressed to develop "home-grown" leadership.

It is believed that the College of Agriculture, through the Agricultural Experiment Station, could serve farmers to better advantage if it devoted its efforts to determining the economic need for cooperative associations, to investigating the success of operating policies followed, and to furnishing advice and assistance with respect to policies of organization and operation.

The West Virginia State Department of Agriculture. To the extent that assistance has been offered to cooperative associations, the West Virginia State Department of Agriculture, which is under the control and supervision of the Commissioner of Agriculture, has worked primarily 
with cooperative marketing associations. The duties of the Commissioner as enumerated in Article 1, Section 4-B, Chapter 19 of the West Virginia laws require that he "promote and encourage the organization of such societies and associations as have for their object the improvement and development of the state's agricultural, horticultural and kindred interests, especially in production, processing for market and distribution." No direct efforts, however, have been made to promote cooperative purchasing associations.

The State Department of Agriculture perhaps could render the most useful assistance to cooperative associations if it directed its efforts along such lines as furnishing legal advice for cooperative associations and establishing a self-supporting auditing service for the purpose of improving existing auditing and accounting practices.

The Federal Government. Aside from assistance of the Baltimore Bank for Cooperatives in collecting statistical data pertaining to cooperative associations, the principal service of the federal agencies has been to supply credit. In 1936, loans from the Baltimore Bank for Cooperatives were outstanding to 7 associations in West Virginia. This sum totaled $\$ 56,000$ and represented 11 percent of all commercial loans made to cooperatives in the state.

\section{The Legal Development of Cooperative Associations in West Virginia ${ }^{11}$}

Consideration of the legal development of cooperative associations in West Virginia, although not applying specifically to purchasing organizations, will be helpful in indicating certain problems common to the organization of either purchasing or marketing associations.

The Cooperative Marketing Act of 1931, which contains the most recent modifications, indicates the possibility of several perplexing problems. In the first place, the powers granted cooperative associations are specific and may not provide the flexibility essential for the most effective operation. For example, cooperative associations are permitted to organize :

". . . to engage in any activity in connection with the marketing or selling of the agricultural products of its members or those purchases from other persons, or with the harvesting, preserving, drying, processing, canning, packing, grading, storing, handling, shipping or utilization thereof, or the manufacturing or marketing of the byproducts thereof; or in connection with the manufacturing, selling or supplying to its members of machinery, equipment or supplies; or in securing and disseminating market information; or in the financing directly, through agricultural credit associations and or otherwise, the above enumerated activities; or in any one or more of the activities specified herein. ..."

Agricultural products in turn are defined to include (Section A)

${ }^{11}$ For a discussion of federal income tax exemptions see Joseph G. Knapp and John H. Lister, "Cooperative Purchasing of Farm Supplies." Farm Credit Administration, Cooperative Division, Bul. 1, 1935, pp. 88-92. 
"horticultural, viticultural, forestry, dairy, livestock, poultry, and any other farm products in their natural form or processed."

No provisions are thus made for consumers and industrial cooperatives, and they would of necessity have to organize under general corporation laws. Neither does the law provide for cooperative associations that may be organized to distribute electrical energy, furnish telephone service, engage in seed and crop improvement, and carry out various phases of soil conservation. Such associations could be incorporated as cooperatives if associations were permitted to organize for any purpose for which general corporations may incorporate.

Section 4-A of the West Virginia act provides that all transactions with non-member's shall be on terms fixed by the association, and such non-members shall not participate in any benefits derived from such transactions. While not mandatory, this provision does tend to encourage discrimination in the treatment of members and non-members. In fact, Cooperative Farm Services after a year's experience with the practice of granting a 2 percent deduction on cash sales only to Farm Bureau members found it advisable to discontinue such practice It should also be mentioned that the continuation of such practice would disqualify the Association from federal income-tax exemption.

Section 10 of the cooperative law states, among other things, that the bylaws of an association may provide that one or more directors, but not more than one-fifth of all directors, may be appointed by any public official or commission or by other directors to represent public interest in the association. The merits of such practice seem questionable. In practical application certain difficulties arise. Frequently such appointees have only a passing interest in the association. In other instances they may exert considerable pressure for the adoption of certain policies which might prove detrimental to the association. In all instances the services of the West Virginia College of Agriculture and the Farm Credit Administration are available for consultation on matters of public policy.

While the West Virginia Cooperative Act provides optional policies as to auditing, membership requirements, and patrons' or members' financial interest in reserves and surpluses, the setting up of definite legal guides in these respects would be helpful in enabling cooperative associations to follow approved business practices.

\section{Date of Incorporation and Business Termination of Retail Purchasing Cooperatives}

Historical information is available as to the dates of incorporation and business terminations of cooperative purchasing associations incorporated in West Virginia. Only scattered data, however, can be obtained as to the number and business operations of unincorporated buying clubs and car-door associations that have operated in the state. A few purchasing associations, all of which are now inactive, were organized under general corporation laws before passage of the first cooperative marketing act in 1921. In a few instances carly warehouse associations remained 
unincorporated for a period of years. A number of the miscellaneous supply associations, such as the Future Farmer associations and lime cooperatives, are not incorporated.

Date of Incorporation. The years of incorporation and the present status of local purchasing associations are shown in Table 3 . Only five of the 20 associations incorporated are in operation today. However, 11 of those listed as inactive were incorporated local county Farm Bureau associations which have affiliated since with Cooperative Farm Services. These warehouses are located at Wellsburg, Philippi and Belington, Petersburg, Moorefield, Romney, Momndsville, Roney's Point, Morgan. town. New Martinsville, Middlebourne, and Charleston. The last three mentioned have been discontinued. New warehouses have been opened at Weston, Princeton, West Union, and Ellenboro.

TABLE 3-Date of incorporation and prescnt status of 20 local cooperative purchasing associations in West Tirginia, 193 .

\begin{tabular}{|c|c|c|c|}
\hline \multirow{2}{*}{$\begin{array}{c}\text { Year of } \\
\text { incorporation }\end{array}$} & \multirow{2}{*}{$\begin{array}{l}\text { Number of } \\
\text { associations }\end{array}$} & \multicolumn{2}{|c|}{ Status in 1937} \\
\hline & & Active & Inactive \\
\hline 1918 & 1 & 1 & \\
\hline 1919 & 2 & . & 2 \\
\hline 1920 & 1 & $\ldots$ & 1 \\
\hline 1921 & $\because$ & . & $\ddot{3}$ \\
\hline 1922 & 3 & . & $\begin{array}{l}3 \\
3\end{array}$ \\
\hline 1923 & 3 & . & 3 \\
\hline 1924 & 1 & $\ldots$ & 1 \\
\hline 1925 & 2 & $\ldots$ & 2 \\
\hline 1926 & 2 & . & \\
\hline $\begin{array}{l}1927 \\
1928\end{array}$ & $\begin{array}{l}1 \\
1\end{array}$ & $\ddot{i}$ & $\begin{array}{l}1 \\
\ldots\end{array}$ \\
\hline 1929 & $\ldots$ & .. & . \\
\hline 1930 & . & $\ldots$ & . \\
\hline 1931 & . & $\ldots$ & .. \\
\hline 1932 & $\ldots$ & $\ldots$ & .. \\
\hline 1933 & $\because$ & $\because$ & $\cdots$ \\
\hline 1934 & $\frac{1}{1}$ & 1 & $\cdots$ \\
\hline $\begin{array}{l}1935 \\
1936\end{array}$ & $\begin{array}{l}1 \\
1\end{array}$ & 1 & $\because$ \\
\hline 1937 & . & . & $\therefore$ \\
\hline Total & 20 & 5 & $15^{1}$ \\
\hline
\end{tabular}

${ }^{1}$ Eleven of the associations listed as inactive were taken over by Cooperative Farm Services between 1930 and 1937 and operated as branch warehouses of that association.

Date of Business Termination. The dates of business termination for the 15 associations no longer active are given in Table 4 . While many of the county Farm Bureau warehouses which reorganized might have maintained their corporate entity for indefinite periods, such symptoms as declining sales, expanding credit, increasing inventories, general lack of interest, and questionable business practices indicated difficulties ahead for many of the local associations. Promotional efforts and the additional appeal of belonging to a large-scale purchasing agency furthered the trend in the direction of establishing a centralized association.

The lengths of time, classified according to five-year intervals, that both active and inactive associations have operated are as follows: 
Years of operation

\begin{tabular}{|c|c|c|c|}
\hline Under 5 & 5 to 10 & 10 to 15 & 15 to 20 \\
\hline number & number & number & number \\
\hline 3 & - & 1 & 1 \\
\hline 5 & 6 & 4 & - \\
\hline
\end{tabular}

It seems that most associations ceasing to do business did so either because of premiature organization or because of incompetent and inefficient leadership and management. In such cases operations usually terminated within one or two years after organization. Other supply organizations existed "neither sick nor well" for a period of years, but because of failure to acquaint patrons with the business policies followed, lack of attention to the necessity of building up adequate reserves, and failure to follow sound business principles, they were not prepared to meet the adverse economic conditions of the early 1930's.

TABLE 4-Date of business termination and reorganization as reported for 15 local cooperative purchasing associations in West Virginia, 1937

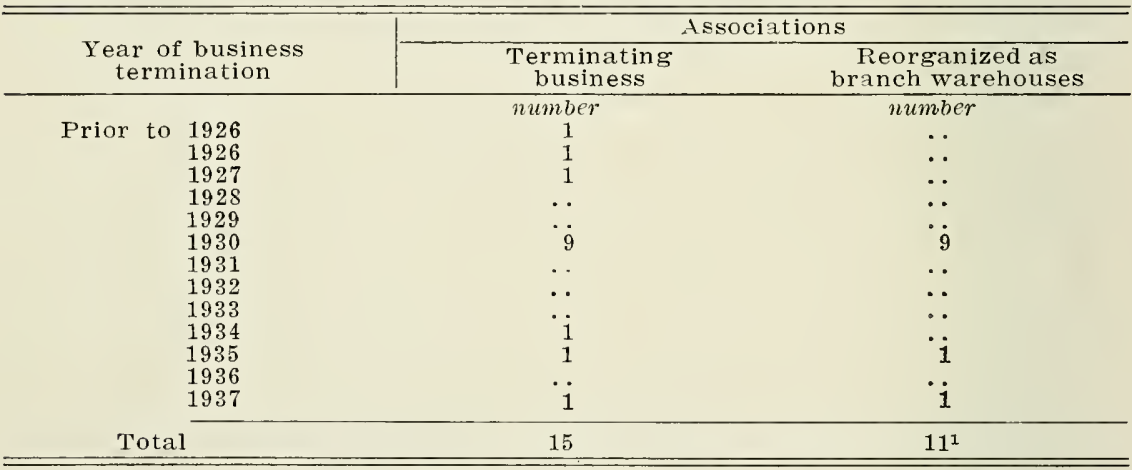

'Three of the associations reorganized as branch warehouses have been discontinued.

\section{ORGANIZATION FEATURES OF COOPERATIVE FARM SERVICES}

The following discussion of the organization features of Cooperative Farm Services gives consideration to: (1) membership relations, (2) management and control, and (3) financial structure.

\section{Membership Relations ${ }^{12}$}

Voting membership in Cooperative Farm Services is limited to holders of common stock. The charter provides that such stock may be held only by paid-up county Farm Bureaus in good standing with the

${ }^{12}$ As a result of the reorganization under consideration by Cooperative Farm Serviees, it is planneil that membership in that association fornerly held by county Faru Bureaus in those connties having braneh warehouses eventualiy will be held by the newly-formed local warehouse assoeiations. Membership in the local warehouse associations is to be held by former holders of preferred stock in Cooperative Farm Serviees who wil continue as patrons of the Iocal associations and by otler famers who meet membership requirements. Up to July 15, 1940, four branch warehouses have been reorganized along these lines. 
state Farm Bureau, and by associations of agricultural producers. Associations of agricultural producers holding common stock in Cooperative Farm Services include: The West Virginia Livestock Marketing Association, the West Virginia Wool Marketing Association, the West Virginia Dairymen's Association, and the Inwood Fruit Growers. There are 2:2 voting county Farm Bureaus holding membership in Cooperative Farm. Services (Fig. 4). They represent about one-half of the county Farm Bureaus affiliated with the state Farm Bureau organization.

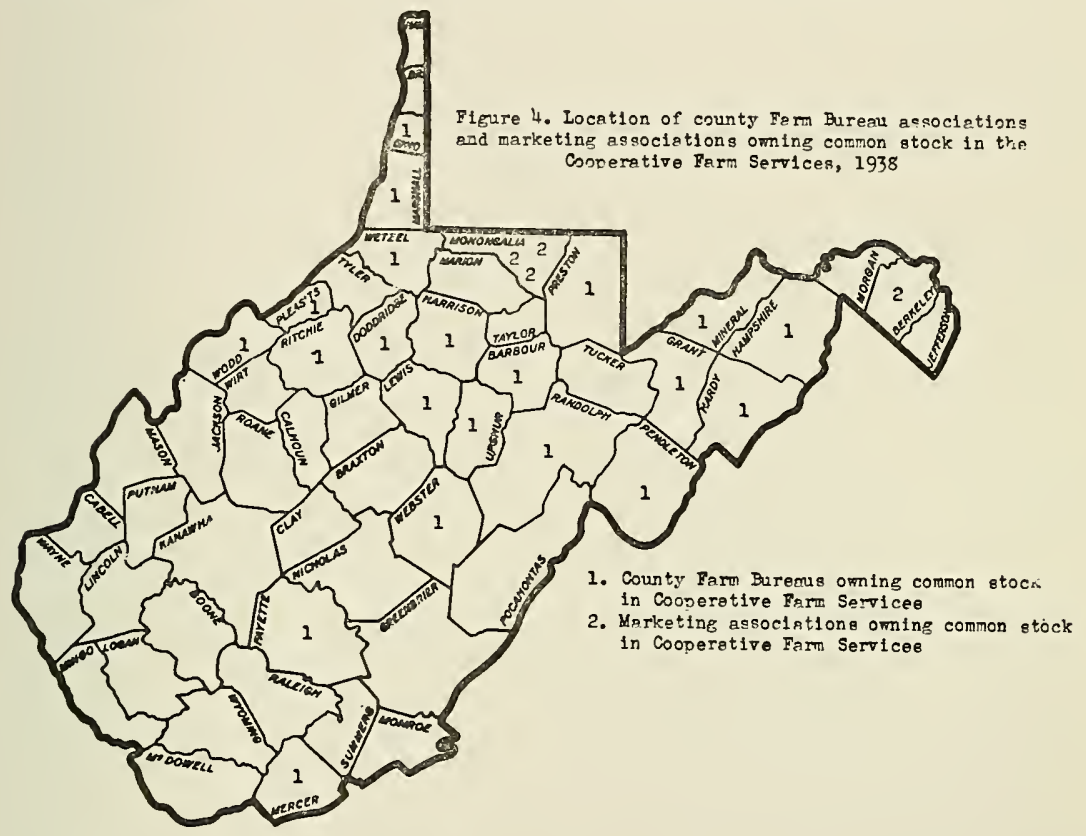

Holders of common stock in Cooperative Farm Services are entitled to one vote each, irrespective of the number of shares of stock held. The voting stock is non-transferable, and no limit is placed on the number of shares of common stock that can be held per member. No provision is included in the Association's charter for determining the share that various common stockholders or patrons may have in accumulated reserves or surplus.

Cooperative Farm Services estimates that 90 percent of its total business is with farmers. The Association reports that 100 percent of its voting stock is held by producers through their local organizations. Even though this is true, it is more significant that all farmers affiliated with the local Farm Bureaus owning common stock are not patrons of Cooperative Farm Services, although through the county Farm Bureaus they do indirectly have a voice in its operation. Membership relations are further complicated by the fact that many farmer's are patrons of the Association, but are not members of the Farm Bureau, and have no 
voice either directly or indirectly in the operation of the organization from which they purchase their supplies. ${ }^{13}$

In two out of 13 counties in which branch warehouse units are located, the county Farm Bureaus own no common stock in Cooperative Farm Services, and consequently neither the connty Farm Bureaus nor any of the patrons of the branch warehouse have any voice in the operation of these establishments. Eleven county Farm Bureaus hold common stock in Cooperative Farm Services and have a voice in the election of its board of directors, even though there are no branch warehouses situated in these counties. The Association engages in business with nine county Farm Bureaus that hold no common stock and consequently have no voice whatever in its operation. There are also private dealers in eight other counties furnishing patrons with Farm Burean products, yet farmers purchasing products of Cooperative Farm Services in these counties have no means of expressing themselves in the operation of the Association (Figs. 1 and 4).

There is danger that such a situation may bring about very sharp cleavage between patrons and members. Neither is it conducive to active participation in business affairs. It also may tend to limit membership to those affiliated with the West Virginia Farm Bureau rather than to promote membership and patronage among all farmers. Even in counties in which general Farm Bureau associations have voting power in the operation of the Association, most patrons are not afforded representation in the affairs of the Association. This is suggested by investigation of the status of patrons of seven branch warehouses of Cooperative Farm Services. Information was obtained as to the total number of patrons: those who were classified as regular and irregular, and the proportion of each of these classifications that were county Farm Bureau members (Table 5).

These data indicate that for the seven warehouses considered, Farm Bureau members constitute 23.2 percent of all patrons. ${ }^{14}$ Thus even in the counties owning common stock and having branch warehouses, slightly less than one-fourth of all patrons of these warehouses had a voice in policy determination, and they only through voting delegates of county Farm Bureaus. This means that three-fourths of the patrons of these establishments have no voice in the operation of Cooperative Farm Services even though they do patronize it. The proportion that sales to Farm Bureau members was of total sales was reported at less than 25 percent by two managers, at between 25 and 50 percent by three managers, and at between 50 and 75 percent by two managers.

It is also interesting to note that in the counties serviced by the seven warehouses referred to, there were 12,620 farmers (1935 Census). Of

${ }^{13}$ The West Virginia Farm Bureau incorporated on February 7, 1939. Membership in the state association may be held by either incorporated or unincorporated county Farm Bureaus.

${ }^{14}$ Cooperative Farm Services reported that cash discounts of $\$ 1,858$ were granted to Farm Bureau patrons in 1938. On the basis of data furnished by the Association, this indicates that Farm Bureau members actually purchased approximately 24 percent of the farm supplies sold on a cash basis. 
TABLE 5-Status of patrons of seven Cooperative Farm Services branch varehouses as indicated by managers, 19381

\begin{tabular}{l|c|c}
\hline \hline Classification of patrons & Total & $\begin{array}{c}\text { Percentage of } \\
\text { total patrons }\end{array}$ \\
\hline Regular & number & percent \\
$\quad$ Farm Bureau & 462 & 12.2 \\
Not Farm Bureau & 1,188 & 31.2 \\
$\quad$ Total & 1,650 & 43.4 \\
\cline { 2 - 3 } Irregular & 419 & 11.0 \\
$\quad$ Farm Bureau & 1,731 & 45.6 \\
$\quad$ Not Farn Bureau & 2,150 & 56.6 \\
$\quad$ Total & 881 & 23.2 \\
All patrons & 2,919 & 10.8 \\
$\quad$ Farm Bureau & 3,800 & 100.0 \\
Not Farm Bureau & & \\
$\quad$ Total & &
\end{tabular}

Patrons were classified as regular or irregular on the basis of the manager's opinion as to whether they purchased more than or less than 50 percent of their regular farm supplies from the association. Lists of county Farm Bureau members were checked by each manager.

'Managers reported that 189 , or 17.6 percent, of the county Farm Bureau members purchased no supplies through branch warehouse associations.

this number 1,070 , or 8.5 percent, were Farm Bureau members, the proportion varying from 2.5 percent in Mercer County to 22.7 percent in Grant County. About 30 percent of the farmers in these counties bought at least some supplies through Cooperative Farm Services.

These facts may help explain why Cooperative Farm Services reports that such factors as membership loyalty, price consciousness, and competition are very important considerations in maintaining and building up satisfactory membership relations. Furthermore, they serve to suggest the need for reorganization so that ownership, membership, and patronage are vested in the same individuals and the development of an effective educational program among patrons and employees. The proposed changes in membership relations represent the plans of the Association to meet the many problems connected with membership relations.

\section{Management and Control ${ }^{15}$}

Reference to Figure 5 will be helpful in explaining the management and control features of Cooperative Farm Services. County Farm Bureau boards consist of one representative for each magisterial district of the county and are elected by the county Farm Bureau membership at large. Each county Farm Bureau owning common stock in Cooperative Farm Services selects one voting delegate. These delegates, together with representatives of the marketing associations owning common stock,

${ }^{15}$ Under the proposed plan of reorganization in those counties in which local warehouse associations are organized, they are to replace connty Farm Bureaus as holders of common stock in Cooperative Farm Services and thus will have a voice in the election of its board of directors. Members of the local associations in turn will elect tle directors of their associations. Preliminary provisions state that Cooperative Farm Services is to have one share and pne vote in each of the local associations. 


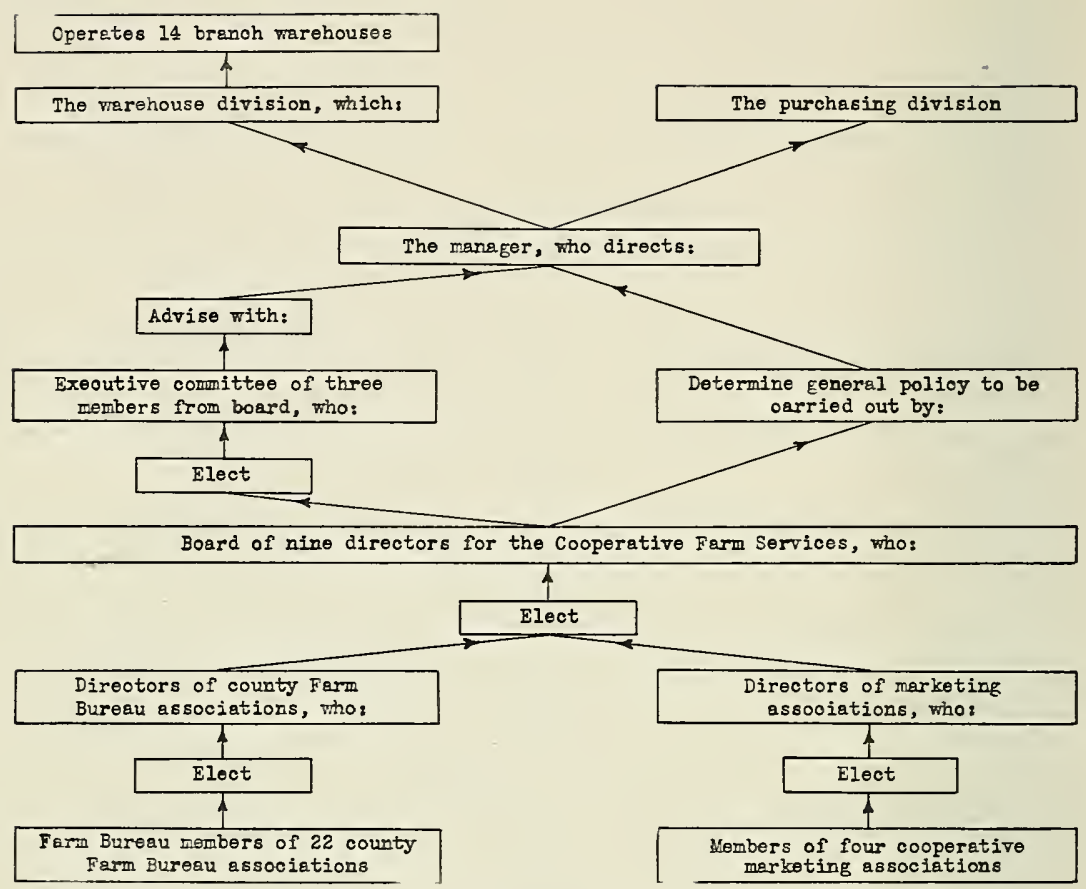

Fig. 5-Organization and management of Cooperative Farm Services

are permitted one vote in the selection of the Association's board of directors. The roting delegates select, from among their group, nine members to serve on the board of directors. The bylaws provide that no two members of the board shall be from the same county.

Directors hold office for a period of three years, three being elected each year. No attempt is made to elect directors according to districts determined by total membership, extent of patronage, number of branch warehouses, or other distributive agencies.

An executive committee of three members consisting of the president, the vice-president, and the secretary-treasurer from the board of directors meets monthly with the manager to consider the general operating policies of Cooperative Farm Services. The board meets four times a year. Each member is paid $\$ 5$ a day for time spent in the service of the Association and is given traveling expenses.

The bylaws of Cooperative Farm Services provide further that "if a director shall cease to belong to the association which holds common stock, he shall be declared removed from the association." They also provide that a stockholder may bring charges against an officer or director by filing them in writing with the secretary-treasurer.

The board of directors requires the manager and all officers, agents. and employees handling funds or property to give "a good and sufficient bond" to be approved by the board, the cost to be paid by the Association.

$$
\begin{gathered}
\text { LIBRARY } \\
\text { WEST VIRGINIA UNIVERSITY }
\end{gathered}
$$


The board is responsible if it fails to check on such bonds and keep them in force. The manager is given general charge of all ordinary and usual business of the Association including the general supervision of the warehouse and purchasing divisions and the purchasing and marketing of all products, merchandise, and supplies handled.

The charter of the Association makes provisions for an audit to be taken twice a year and to include: (1) balance sheets, (2) operating statements, (3) itemized statements of expenses, and (4) a certified statement of inventories.

To assist managers of branch warehouses in matters of policy and operation, the Association has worked out arrangements with presidents of local county Farm Bureaus to appoint advisory committees consisting of three members. Although these committees should offer opportunities for breaking down barriers between patronage and management, warehouse managers report that they were discontinued after 1936 .

The warehouse division exercises control over the branch warehouses. Daily reports are required with respect to sales, inventories, and accounts receivable. All receipts are deposited daily by local warehouse managers, and all bills are paid by the Association.

\section{Financial Structure ${ }^{16}$}

Cooperative Farm Services is financed on a capital-stock basis. As provided for in its charter, $\$ 500,000$ of capital stock is authorized. Of this amount $\$ 25,000$ is common stock, and $\$ 475,000$ is preferred stock. Both classes of stock have a par value of $\$ 100$ per share. The preferred stock is non-assessable, cumulative, and carries provisions for a minimum annual dividend rate of 6 percent and a maximum rate of 8 percent. The bylaws further provide that common stock is non-transferable except as approved by the Association. It is also provided that the transferring stockholder shall be free from indebtedness to Cooperative Farm Services.

The outstanding stock as of December 31, 1938, included $\$ 141,185$ of preferred stock and $\$ 4,700$ of common stock. The bylaws of the Association in no way limit the amount of stock that may be held by stockholders, although they do provide that common stock may be held only by paid-up county Farm Bureaus and affiliated producer groups.

In event of dissolution, preferred stockholders are entitled to be paid out of assets to the extent of 100 percent with the remaining assets or funds to be divided among common stockholders according to their respective shares. Preferred stock may be redeemed at the option of the board of directors, but all must be redeemed within 25 years of the date of issuance.

Cooperative Farm Services encountered difficulty when first organized in interesting farmers in assuming financial responsibility. This explains why it has been financed largely from preferred stock. At one time several thousand dollars were borrowed upon the signature of the

${ }^{16}$ Plans are under consideration wherebs the preferred stock orvned by Cooperative Farm Services in those counties having branch warehouses that are being reorganized as local associations will become the comnion stock of the local association. It is 10 carry membership and voting rights, have the par value of the preferred stock, and be non-interest-bearing. 
board of directors. At present money is borrowed only for short-term operating purposes and is secured from commercial banks at an interest rate of 6 percent.

The management of 14 active branch warehouses by Cooperative Farm Services requires large amounts of capital for facility and operating purposes. For example, in 1938 the real estate, buildings, and equipment of the warehouse division were valued at $\$ 35,375$, even though nine warehouses were rented; receivables totaled $\$ 81,246$; and merchandise inventories were valued at $\$ 91,097$ (See Appendix, Table A-V).

In most localities where new branch warehouse units were established by the Cooperative Farm Services. preferred stock was offered for sale, and where existing cooperative warehouses were taken over, arrangements were worked out by which the stock of these associations was exchanged for the preferred stock of the Cooperative Farm Services. Table 6 shows that between 1930 and 1938 preferred stock has varied from about three-fifths to four-fifths of the total liabilities and net worth of the Association. During this same period preferred stock regularly has comprised about 75 percent of the Association's net worth, surplus approximately 20 percent, and common stock somewhat less than 5 percent.

TABLE 6-Total liabilities and net worth and percentage distribution of various liability and net worth items of Cooperative Farm Services, 1930-1938

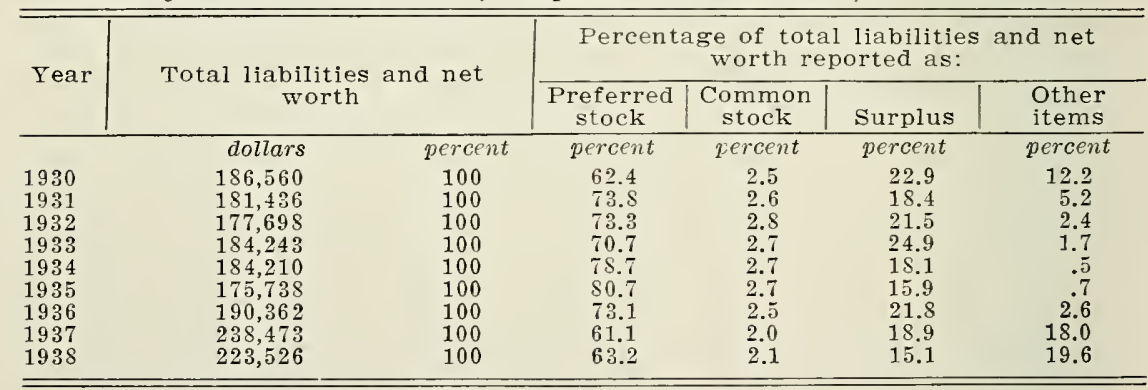

The advantage of using preferred stock in a financial program lies largely in the fact that it offers an easy means of raising money. In many instances, however, the advantages of financing cooperative associations with preferred stock are more than offset by its inherent weaknesses. In the first place, the possibility exists for ownership of an association to be vested largely in non-patron and non-member individuals whose interest in dividends may readily be in opposition to that of the patrons of farm-supply associations who are primarily interested in sceking quality goods, economy of operation, and adequate service. Investors may be inclined to "leave well enough alone" and to bring pressure to bear against any change in policy. Changes are usually opposed either because failure would eliminate their holdings or because success might mean that the association would no longer be dependent upon preferred stock as a means of financing.

In the second place, preferred stock may seriously deplete working capital in times of adverse economic conditions if it provides for cumula- 
tive interest. In "retain" plans, whereby cooperatives are financed out of funds obtained from operations, this objection may be either wholly or partially orercome, since patrons, because of their financial interest in an association, are usually willing to pass interest payments or to accept reduced interest rates during periods of emergency.

In the third place, there is a tendency for members and patrons to be indifferent to the welfare of a cooperative when ther have little or no financial interest in it. It has become well established that financial responsibility placed squarely upon those using an assoeiation does much to stimulate personal interest in its suceess. Thus the poliey of financing is closely associated with means of establishing and maintaining membership interest and of conducting membership edueation.

A consideration of the first disadvantage of preferred stock, namely, ownership rested in non-members and non-patrons, is important as it applies to Cooperative Farm Services. A check was made to determine the extent to which preferred stock of Cooperative Farm Services is owned by Farm Bureau members. Even though not all Farm Bureau members patronize this cooperative, such comparison is highly significant because it tends to show the extent to which ownership and management of the Association is in the hands of the same individuals. Unfortunately, the list of stockholders was available only for 1934 and this had to be compared with membership for 1938. While it is appreciated that these data do not offer the most satisfactory basis for comparison, it is believed, however, that the results are quite indicative of the extent of ownership by members, since the turnover in preferred stock has been relatively small.

TABLE 7-Distribution of stockholders and of preferred stock held in Cooperative Farm Services as of 19341

\begin{tabular}{|c|c|c|c|c|c|}
\hline \multirow[b]{2}{*}{ Type of stockholder } & \multicolumn{2}{|c|}{ Stockholders } & \multicolumn{3}{|c|}{ Preferred stock } \\
\hline & Total & $\begin{array}{c}\text { Percentage } \\
\text { of total }\end{array}$ & Value & Shares & $\begin{array}{c}\text { Percentage } \\
\text { of total }\end{array}$ \\
\hline & number & percent & dollars & number & percent \\
\hline $\begin{array}{l}\text { Non-Farm Bureau members } \\
\text { Farm Bureau: }\end{array}$ & 357 & 54 & 74,700 & 747 & 55 \\
\hline $\begin{array}{l}\text { Individual members } \\
\text { County Farm Bureaus }\end{array}$ & 276 & 41 & $\begin{array}{l}38,415 \\
18,400\end{array}$ & $\begin{array}{l}384.15 \\
184\end{array}$ & 28 \\
\hline Unclassified & 29 & 4 & $\begin{array}{r}10,400 \\
5,425\end{array}$ & 54.25 & $\begin{array}{r}10 \\
4\end{array}$ \\
\hline Total & 668 & 100 & 136,940 & $1,369.40$ & 100 \\
\hline
\end{tabular}

${ }^{\mathbf{1} C o m p a r e d ~ w i t h ~ F a r m ~ B u r e a u ~ m e m b e r s h i p ~ f o r ~} 1938$.

The financial interest of Farm Burean and non-Farm Bureau stockholders in Cooperative Farm Services is shown in Table 7 . Of all stockholders, 54 pereent were not members of county Farm Bureaus, and they owned 55 pereent of the outstanding preferred stock. While Farm Bureau members totaled 41 percent of the stockholders, they owned only 28 percent of the stock. Since some of the county Farm Bureaus have now divided the preferred stock they owned among members, the proportion of Farm Bureau members owning stock in Cooperative Farm Services is somewhat higher than in 1934. This addition to holdings of Farm Bureau members still limits their interest to not over two-fifths of the preferred stock outstanding. This situation suggests again the 
desirability of reorganizing in such a way that ownership, membership, and patronage are in the hands of the same individuals.

The data presented in Table 8 call attention to the second objection to preferred stock as it pertains to the operation of Cooperative Farm Services, namely, the expense of continuing this system of financing. During the past eight years the Association has paid out approximately $\$ 65,000$ in dividends on such stock. This represents an annual average expenditure of about $1 \frac{1}{2}$ percent of the warehouse sales, or a sum equivalent to 10 to 15 percent of the warehouse operating expenses, which is equivalent to 8 to 11 percent of the consolidated operating expenses of the Association. Put in another way, total interest charges on preferred stock have aggregated about twice the amount of surplus reported in the consolidated balance sheets for the 1938 fiscal year.

TABLE 8-Total preferred stock dividends and percentage that preferred stock dividends are of warehouse sales, warehouse operating expenses, und consolidated operating expenses as reported by Cooperative Farm Services, 1931-1938

\begin{tabular}{|c|c|c|c|c|}
\hline \multirow{3}{*}{ Year } & \multicolumn{4}{|c|}{ Preferred stock dividends } \\
\hline & \multirow[b]{2}{*}{ Total } & \multicolumn{3}{|c|}{ Percentage of total: } \\
\hline & & $\begin{array}{c}\text { Warehouse } \\
\text { sales }\end{array}$ & $\begin{array}{l}\text { Warehouse } \\
\text { operating } \\
\text { expenses } \\
\end{array}$ & $\begin{array}{c}\text { Consolidated } \\
\text { operating } \\
\text { expenses } \\
\end{array}$ \\
\hline & dollars & jercent & percent & percent \\
\hline $\begin{array}{l}1931 \\
1932 \\
1933 \\
1934 \\
1935 \\
1936 \\
1937 \\
1938\end{array}$ & $\begin{array}{l}7,511 \\
7,803 \\
7,812 \\
8,154 \\
8,508 \\
8,651 \\
8,394 \\
8,483\end{array}$ & $\begin{array}{l}1.3 \\
2.0 \\
1.7 \\
1.6 \\
1.8 \\
1.6 \\
1.2 \\
1.3\end{array}$ & $\begin{array}{r}11.5 \\
15.7 \\
13.5 \\
12.6 \\
14.5 \\
13.2 \\
10.9 \\
9.6\end{array}$ & $\begin{array}{r}7.0 \\
10.3 \\
9.2 \\
9.8 \\
11.2 \\
10.3 \\
8.8 \\
8.0\end{array}$ \\
\hline
\end{tabular}

${ }^{1}$ These dividends are paid out of earnings and are not classified in operating expenses. Operating expenses are used only as a basis for comparison.

The extent of these costs serves to indicate the need for developing a financial program which will enable the Association to operate with cheaper capital. This is especially true since cooperative credit agencies are in a position to furnish associations with capital at reduced costs. In this connection the possibility of calling the preferred stock and refinancing through the Bank for Cooperatives at reduced interest charges presents a possibility worthy of careful consideration by the Association, or by subsequently incorporated local county warehouse associations.

While Cooperative Farm Services is faced with the immediate task of refinancing its preferred stock and of eliminating the financial burden which such stock entails, consideration should also be given to the establishment of a permanent policy of financing. Careful thought might be given to building the future financial program of the association around its patrons.

The experiences of many cooperative purchasing associations have established the soundness of this method of securing funds for normal business operations. Many associations have followed the policy of making deductions from sales, usually from 1 to 2 percent. These deductions are used as the basis for issuing certificates of equity or revolving certificates of indebtedness to patrons. 
Through such a system of "retains", associations are financed by active members. Certificates of equity issued on the basis of retains from sales might or might not carry provisions for definite dates of maturity or for the payment of interest. In reality they would'simply mean that patrons lend the Association the use of funds for operation, and the Association in turn agrees to repay this money as soon as necessary deductions have been made from operations in subsequent years.

Such a plan of refinancing offers the alternative of reducing and eventually eliminating interest charges, on one hand, or of paying interest to active member's on the other. As it now operates, Cooperative Farm Services pays the greater part of its anmual $\$ 8,500$ preferred interest charge to individuals who are not members or patrons of the Association, but who use it as an investment institution. The adoption of a policy creating certificates of equity, or the equivalent, to represent the financial interest of patrons in the Association would lead toward either the elimination of interest expense altogether or result in making interest payments to the actual patrons of the Association and at such interest rates as it might decide. The possibility of creating a definite financial interest among patrons also offers one means of developing their interest in its success.

With respect to the present financial policies of Cooperative Farm Services it is evident that: (1) financing the Association through 6 percent cumulative preferred stock places a heavy financial burden on the Association; (2) ownership of Cooperative Farm Services is vested only to a minor extent with members of the county Farm Bureaus-the governing bodies of the Association-and to a lesser extent with patrons; and (3) a change in financial policy would offer possibilities for immediately reducing interest charges and for improving membership interest in the success of the Association. This should enable the organization to adopt a long-time financial program designed to place financial control in the hands of patrons and at the same time present an opportunity for improving membership relations by establishing financial responsibility among those who avail themselves of the services of the Association.

\section{OPERATING SET-UPIOF COOPERATIVE FARM SERVICES}

Attention is given in this section to: (1) method of operation, purchasing policy, (3) sales policy, (4) side line activities, and accounting procedure.

\section{Method of Operation ${ }^{17}$}

Cooperative Farm Services operates through a warehouse and pur-

\footnotetext{
${ }^{17}$ When carried to completion, the proposed reorganization of Cooperative Farm Services will mean discontinunce of the warehouse department. The purchasing department will continue operations fundamentally as at present. This means, however, that local warehouses instead of Cooperative Farm Services will become concerned with surh matters as purchasing and sales policies, side line activities, and problems of acconnting. Therefore much of the discussion relative to methods of operation may eventualiy apply as much to local farm supply associations as it loes at present to Cooperative Farm Services.
} 
chasing department. The warehouse department is charged with the responsibility of operating and managing the Association's 14 branch warehouses. The purchasing department handles no supplies, but functions as the buying agency for the Association. Depending upon the type of business conducted, the Association in the varied capacities of agent, dealer, and broker, through its purchasing department, obtains supplies for its warehouse department, county Farm Bureaus, groups of Farm Bureau members, cooperative associations, and independent dealers.

The location and kinds of distributive agencies with which Cooperative Farm Services is affiliated is shown in Figure 1. It may be observed that with the exception of one branch warehouse in Mercer County, all warehouses are located in the northern third of the state. County Farm Bureaus and private dealers handling supplies of Cooperative Farm Services are scattered throughout the state, although they tend to predominate in the northern half and usually are not in areas serviced by branch warehouses.

\section{Purchasing Policy}

Kinds of Supplies Handled. As a general rule, the manager of the warehouse division determines the type of supplies to be handled by the branch warehonses. One of the larger warehouses combines the sale of gasoline with its general warehouse business. In some localities in which the state and county Farm Bureaus sponsor rural electrification associations, a special effort is made to sell electrical equipment of all kinds; in some locations the sale of groceries is given consideration; and in a few of the warehouses a definite practice has been established whereby such farm produce as poultry, eggs, cream, grain, hay, and countrycured hams are purchased. Farm products such as hay and grain are usually resold locally, but most of the eggs, cream, and hams handled are routed through established distributive agencies.

The data showing the monthly distribution of purchases, which is presented in Table 9, were obtained by checking invoices of the Association and serve to give some indication of the seasonal character of the supplies handled. It will be observed that approximately one-half the total purchases are made during the three months of March, April, and May and that only about one-eighth of the total purchases are made during November, December, and January. Significant differences in the distribution of purchases exist for the various commodities. Feeds show the most uniform distribution, seeds and fertilizer the least. Such seasonable distribution of sales suggests the difficulty of obtaining complete utilization of equipment and labor.

In a special effort to spread business the warehouse division has recently added a complete line of electrical equipment at many of the branch warehouses. While this policy may bring about an increased volume of sales it has some of the same inherent weaknesses that are common in the cooperative distribution of most types of equipment. To handle this kind of business successfully, cooperative associations should consider: (1) the necessity of meeting a growing demand for competent 


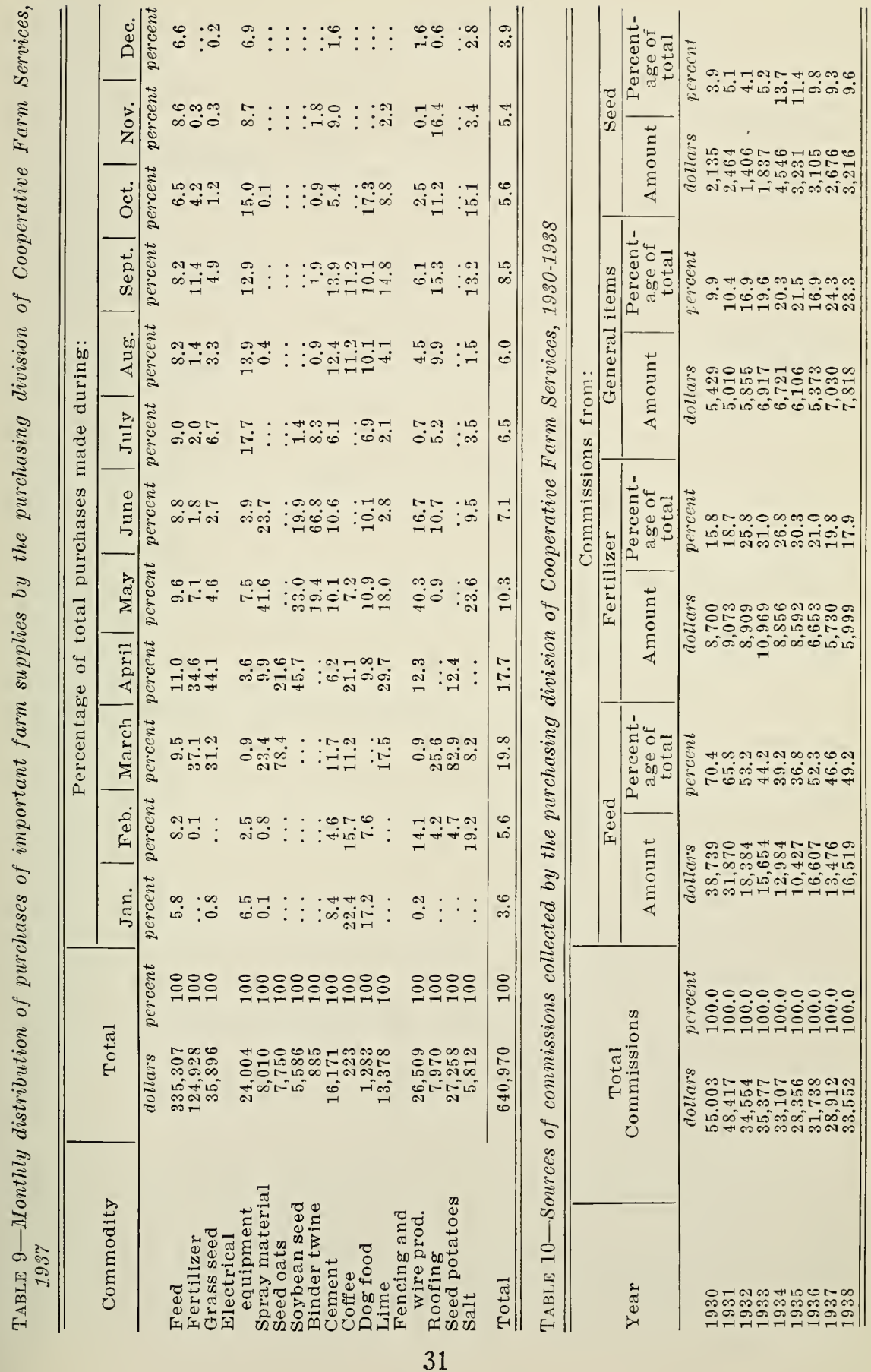




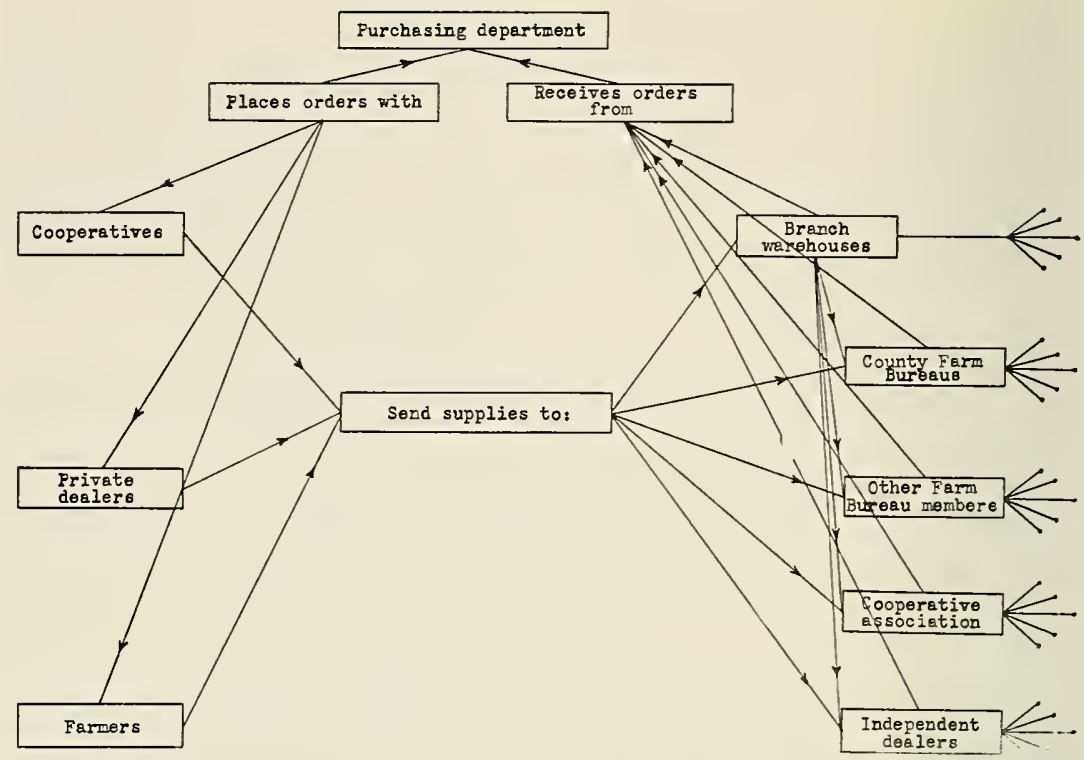

Fig. 6-Distribution of farm supplies through Cooperative Farm Services

service for these products as they become older, (2) the necessity of making arrangements to handle an appreciable amount of second-hand products if resales are to be made, and (3) the facts that two-thirds of the farms in West Virginia are classified as self-sufficing or part-time and that as a result only limited uses for many types of electrical equipment exist. In many instances the purchasing power of farmers also is definitely limited.

The Association attempts to handle products of various grades in order to meet competitive prices. Both open and closed formula feeds are available. With respect to electrical equipment, Westinghouse products are sold in addition to regular "co-op" goods obtained from cooperative distributive agencies. The Association states that its general policy is to handle high-quality products. While the Association is in a position to render appreciable service to farmers by improving quality, it must be kept in mind that quality goods may reduce rolume of business if members are not educated to the advantages of such products. This suggests that cooperative purchasing associations in the state may find it necessary to coordinate an aggressive educational program with attempts to handle quality products.

Purchasing Methods. Examination of Figure 6 will be helpful in explaining the purchasing methods of Cooperative Farm Services. As has been indicated, distributive agencies affiliated with the cooperative obtain supplies by: (1) following the practice of sending orders direct to the purchasing division; (2) purchasing directly from the agencies with which the purchasing department has established business relations ; and (3) arranging to secure supplies directly from the nearhy branch 
warehouses. The purchasing division in turn has established business relations with wholesale cooperative associations, private manufacturers, and farmers. These agencies furnish supplies directly to the agencies placing orders.

The purchasing division has made arrangements with the majority of the dealers furnishing supplies to have its commissions remitted directly. In a few instances, depending on arrangements with manufacturers, commissions are paid by the agency purchasing the supplies. While the policy followed with respect to commissions charged varies with the commodity handled, the purchasing division averages about 3 percent of the purchase price.

The purchasing division secures its feed through the Farm Burean Milling Company of Chicago, Illinois; some electrical and related equipment from the United Cooperatives, Inc.; and the majority of its petroleum supplies other than gasoline through the National Cooperatives, Inc.

The Farm Bureau Milling Company has a contract with the Arcadia Milling Company of Chicago, Illinois, to mill feeds according to specifications. The State Farm Bureau Purchasing Associations of Ohio, Pennsylvania, West Virginia, Indiana, Michigan, and Illinois own and operate the Farm Bureau Milling Company and agree to purchase feeds through it. The amount of commissions charged on feed by the purchasing division is worked out by the manager with the assistance of the board of directors. It averages from $\$ 2.50$ per ton on special feeds to as low as 50 cents per ton on such common feeds as corn, oats, bran, and cottonseed meal.

Cooperative Farm Services, the Farm Bureau Supply Association of Pennsylvania, and the Southern States Cooperative are members of, and own and operate, the Cooperative Fertilizer Services, Ine., of Baltimore, Maryland. Since 1936, fertilizer has been obtained through this association. Each association agrees to purchase its fertilizer through this association and places with it a tentative estimate of yearly requirements.

No definite policy exists with respect to other commodities. The Association follows the practice of shopping around for seeds. Similar arrangements are made for other products. The warehouse division, with the assistance of the purchasing division, is usually in position to take cash and quantity discounts. Since the purchasing division of the Association handles few products, it has no expenses normally associated with warehousing, but only administrative and clerical expenses.

\section{Sales Policy ${ }^{18}$}

Method of Sales. In an effort to develop and maintain a large volume of business, the purchasing division of the Association has followed the practice of employing salesmen to visit distributive agencies. The sales

${ }^{18}$ Cooperative Farm Services reports that it recently has inaugurated a delivery policy calling for charges bs all warehouses to be made on a zone basis. The Assoniation further follows the policy of making deliveries onis from established rou $\mathrm{s}$. In an effort to reduce delivery costs the number of tricks operated has also been decreased. 
force employed by the Association has varied from one to four persons since 1929. In addition, arrangements frequently have been made îrom time to time with farmers or local dealers to take orders for feed on a commission basis. While still followed in some areas, this practice is no longer common.

It is significant that in many instances the importance of the retail warehouse as the center frequented by farmers in selecting their supplies seems to be on the decline. This is true even among those warehouse units buying farm products and selling appreciable amounts of household supplies. Managers of branch warehouses estimate that between one-half and two-thirds of the total business is done through the delivery of products direct to the farm. Orders are either phoned in or given to truck drivers, many of whom make regular trips delivering supplies. To this end all but one of the branch warehouses operate delivery trucks. Two managers reported making definite delivery charges, one of 5 cents per. bag and one of 10 cents per bag; two made charges "as justified," and two made no charges. Managers feel that competition is forcing them to discontinue the practice of making fixed charges for delivery service. In order to compensate those patrons interested in purchasing direct from the warehouse a policy could be formulated of granting discounts equivalent to delivery costs.

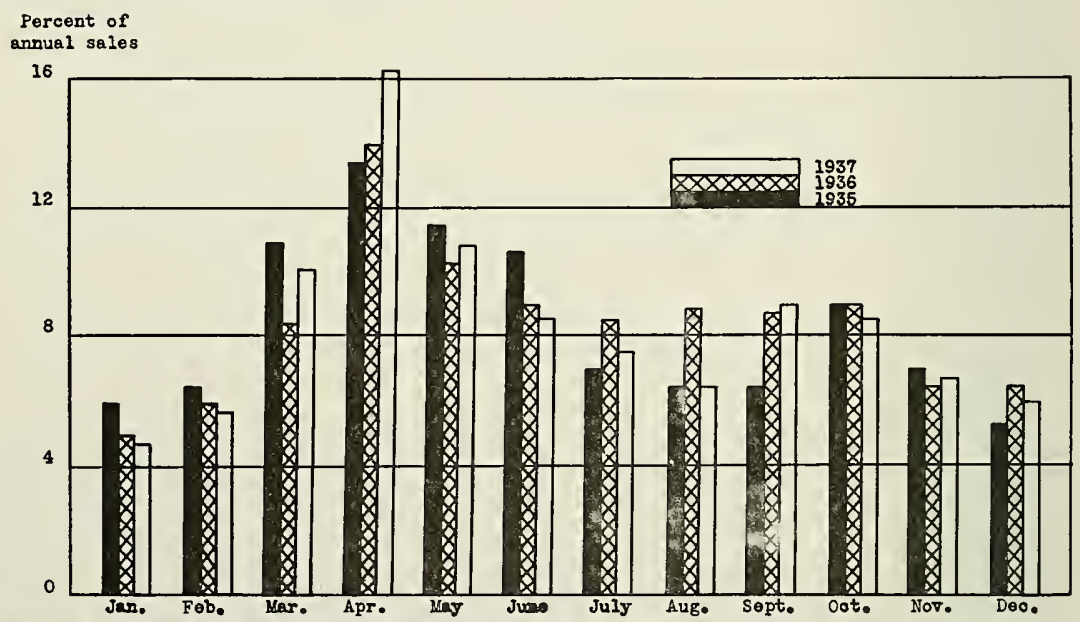

Fig. 7-Monthly distribution of annual sales. s reported by the warehouse division of Cooperative Farm services, 1935-1937

$D$ istribution of Sales. Figure 7 shows the monthly distribution of total warehouse sales for the years 1935-1937. It may be noted that the months of March, April, May, and June constitute the peak business period with a minor peak usually in September and October. The midsummer and midwinter months are slack periods. About one-half of all sales are made in the four months of peak business and only one-third during the six slack months.

For the three-year period, 1935-1937, the percentage distribution of 
monthly sales by the warehouse division of Cooperative Farm Services was as follows:

Percentage distribution for:

Month

January

February

March

April

May

June

July

August

September

October

November

December

Total
1935

percent

6.0

6.5

11.1

13.6

11.4

10.3

6.9

6.4

6.6

9.0

7.0

5.2

100.0

$\frac{1936}{\text { percent }}$

4.9

5.9

8.3

14.0

10.2

8.6

8.5

8.7

8.6

9.1

6.6

6.6

100.0
1937

percent

4.7

5.6

10.1

16.3

10.4

8.5

7.6

6.4

8.8

8.5

6.8

6.3

100.0

Such a seasonal distribution of business suggests the desirability of investigating the possibilities of: (1) adding new supplies to the lines already carried, (2) increasing the available grades of the same products, and (3) giving careful attention to possibilities of combining a marketing and supply business in regions of limited agricultural development.

Inventory Control. The warehouse division has experienced difficulties in controlling inventories. While it is appreciated that operating: warehouses in regions of both limited and varied agricultural development necessitate relatively high and slow-moving inventories, it would be to the advantage of the Association, through its accounting department, to set up carefnl standards for the elimination of slow-moving items and for the adaition of such supplies as local conditions warrant. Although it is desirable to increase business volume, care must be taken not to do so through an increase in slow-moving items, which result in additional increases in overhead. The relationship of anmul sales to inventories for the warehouse division is as follows:

\begin{tabular}{cccc} 
Year & Sales & Inventories & $\begin{array}{c}\text { Inventory per } \\
\text { dollar sales }\end{array}$ \\
\cline { 2 - 2 } 1930 & dollars & dollars & cents \\
1931 & 613,043 & 50,187 & 8 \\
1932 & 580,140 & 51,150 & 12 \\
1933 & 383,711 & 47,588 & 12 \\
1934 & 469,440 & 57,281 & 12 \\
1935 & 527,528 & 64,498 & 13 \\
1936 & 479,061 & 62,953 & 15 \\
1937 & 542,724 & 83,779 & 14 \\
1938 & 673,502 & 93,493 & 14
\end{tabular}

Advertising. Cooperative Farm Services has not deemed it advisable to spend large sums of money on advertising. Advertisements 
are usually run in the West Virginia Farm News. Letters and circulars are frequently sent out calling attention to the supplies handled. Exhibits are often made at annual state and county Farm Bureau meetings and at various fairs. Recently exhibits have been devoted largely to electrical equipment and less to the farm-supply phase of business.

Patronage Dividends. During the early years of operation, patronage dividends were paid on seeds and fertilizer. In 1929 these dividends amounted to 5 percent on seeds and $\$ 1.00$ per ton on fertilizer. This practice was later discontinued, but since 1935 a 50 -cents-per-ton dividend has been paid on fertilizer. However, in the case of the warehouse division these dividends are not returned to patrons of warehouses, but applied to accounts due the purchasing division. Dividends to county Farm Bureaus likewise are paid to those agencies rather than to the patrons ordering supplies. The same practice is followed with other distributive agencies.

Credit Control. Cooperative Farm Services attempts to hold current accounts to 30 days. The board of directors authorizes the management to deduct losses from bad debts from salaries of warehouse managers. 'This practice lias been resorted to, however, only when it is felt that managers have been unreasonably lax with respect to credit control. The Association also encourages managers to work among patrons for the purpose of both increasing sales and watching accounts.

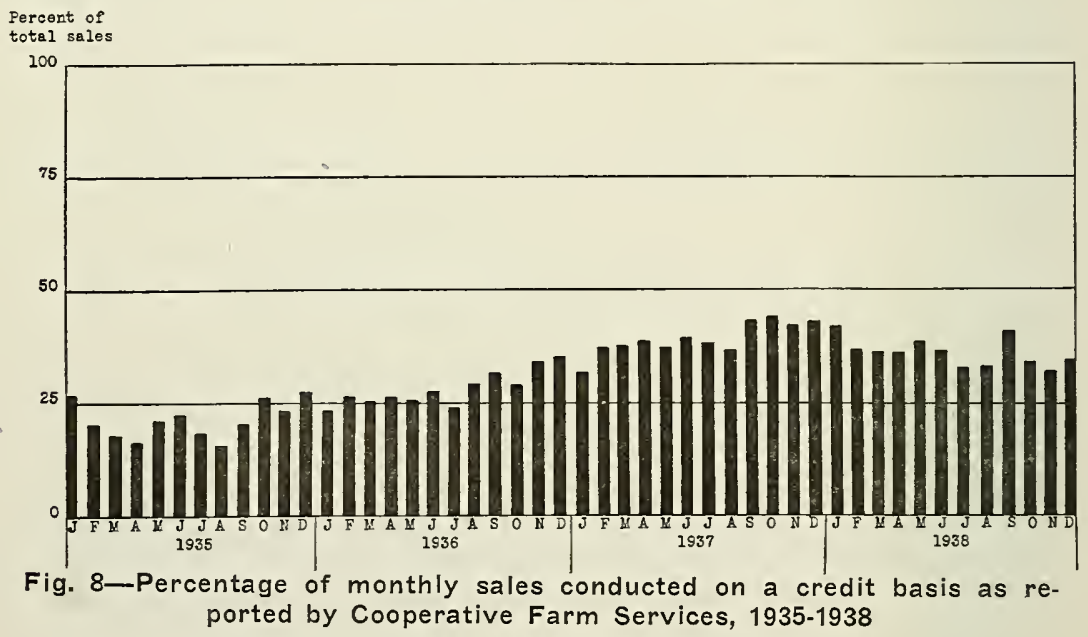

From 1935-1938, credit sales have increased from around 20 to about 40 percent of all sales (Fig. 8). These data suggest that any attempt toward increasing credit either because of adverse economic conditions $\mathrm{OI}^{2}$ because of increased efforts to build or maintain volume, if such volume is obtained at the expense of relaxing credit control, may cause serious difficulties.

The trend in the percentage of toal sales conducted on a credit basis by the warehouse division of Cooperative Farm Services as reported monthly for 1935-1938 was as follows: 
Percentage of sales on credit for:

\begin{tabular}{|c|c|c|c|c|}
\hline Month & 1935 & 1936 & 1937 & 1938 \\
\hline & $\begin{array}{c}\text { percent } \\
27.0\end{array}$ & percent & $\begin{array}{c}\text { percent } \\
33.0\end{array}$ & percent \\
\hline $\begin{array}{l}\text { January } \\
\text { February }\end{array}$ & $\begin{array}{l}21.0 \\
21.1\end{array}$ & 27.2 & $\begin{array}{l}30.0 \\
38.0\end{array}$ & $\begin{array}{l}43.2 \\
37.0\end{array}$ \\
\hline March & 18.4 & 25.3 & 38.6 & 37.4 \\
\hline April & 16.9 & 25.8 & 40.2 & 36.4 \\
\hline May & 21.4 & 25.3 & 38.5 & 39.2 \\
\hline June & 22.8 & 28.3 & 41.0 & 37.6 \\
\hline July & 17.7 & 245 & 39.5 & 34.0 \\
\hline August & 15.7 & 28.6 & 37.4 & 34.3 \\
\hline September & 20.7 & 31.8 & 43.6 & 34.9 \\
\hline October & 26.0 & 29.2 & 441 & 34.3 \\
\hline November & 24.1 & 35.2 & 42.9 & 32.9 \\
\hline December & 27.7 & 35.5 & 43.6 & 34.3 \\
\hline
\end{tabular}

Another indication of the extent to which credit is granted is found in the relationship of receivables to sales, which for the warehouse division were reported as follows:

\begin{tabular}{|c|c|c|c|}
\hline \multirow{2}{*}{ Year } & Sales & Receivables & $\begin{array}{l}\text { Receivables per } \\
\text { dollar of sales }\end{array}$ \\
\hline & dollars & dollars & cents \\
\hline 1930 & 613,043 & 55,799 & 9 \\
\hline 1931 & 580,140 & 40,715 & 7 \\
\hline 1932 & 383,711 & 42,055 & 11 \\
\hline 1933 & 469,440 & 48,272 & 10 \\
\hline 1934 & 527,528 & 36,733 & 7 \\
\hline 1935 & 479,061 & 34,133 & 7 \\
\hline 1936 & 542,724 & 35,153 & 6 \\
\hline 1937 & 673,502 & 71,443 & 11 \\
\hline 1938 & 667,429 & 81,246 & 12 \\
\hline
\end{tabular}

\section{Side Line Activities}

As has been suggested, Cooperative Farm Services markets various agricultural products in addition to its regular supply business. The West Virginia Potato Growers Association at one time marketed their potatoes under the "Mountain State" brand through the Association on a commission basis. This was the most important marketing venture undertaken, and in 1929 sales were reported at $\$ 124,069$. Cream is purchased at four warehouses, and at the Moundsville branch warehouse commissions for cream, charged at the rate of 3 cents per pound of butterfat, amount to about $\$ 50$ a month during the summer. Purchases of farm products by 14 branch warehouses were reported at approximately $\$ 28,000$ or about 5 percent of the annual business in 1937 .

\section{Accounting Procedure}

The purchasing department keeps accounts of commissions received according to four general classifications which include feed, seed, fertilizer, and general items. The latter classification includes electrical equipment, building material, and all other miscellaneous supplies. While an account is kept of commissions charged the warehouse division. 
no attempt is made to secure information as to the amount of commissions collected from the distributive agencies. These data as well as complete sales information would be useful in indicating the nature and extent of business with various distributive agencies and in analyzing the need for supplies in different agricultural areas.

With respect to the warehouse division, complete daily records are kept as to the purchases, sales, and inventory for each warehouse. Cash and credit sales, accounts receivable, and similar information are kept on a monthly basis. In order to set up comparative standards of operating efficiency the Association may find it desirable to obtain such data as (1) a division between supplies sold and farm products marketed and (2) gross margins for principal products handled. Such data would be helpful in furnishing information about business policies and operating efficiency of the division. Practical questions relating to such problems as margins to charge, products to handle, and types of business to engage in, all depend mpon accurate information if business practices are to be based on sound policy.

It is believed also that it would be advisable for the Association to give careful consideration to the advantages resulting from a revision of its accounting and auditing practices. Much of the valuable information obtained at present could be used to advantage in serving as a basis for determing operating policies or as a check on operating performance

Definite possibilities for further acquainting patrons with the business activities of the Association might include consideration of the following suggestions :

1. It would be helpful to show the yearly disposition of net income and to reconcile the net income or loss account of the Association from year to year.

2. A more complete description of the nature of the receivables, payables, and general reserve items would be desirable.

3. Certain changes in the handling of various items would be beneficial. Such changes might well include these suggestions: (1) the assets and liabilities should be divided into current and fixed items, and net worth should be separated from liabilities; and (2) departmental ac:counts should be set up to show the true condition of each department, and since preferled stock is a legitimate obligation of the warehouse department, dividends on this stock should be chargeable to it and not to the purchasing department, as is the practice at present. It is only when careful consideration is given to financial statements that they can be used as a measuring stick to indicate the solvency; status of the protection of investment; and credit, collection, and general operating policies of the Association.

Other improvements are possible in addition to those suggested for the balance sheets and for operating statements. It would be helpful for the Association to give attention to: (1) the setting up of records for' the purchasing division, designed to show the monthly distribution of business (in dollars and in volume) for the principal commodities by each individual distributive outlet; this is to be done in order to permit 
analysis of trends in volume and of the effectiveness of various distributive outlets; (2) each branch warehouse should keep detailed accounts of purchases from Cooperative Farm Services and other sources, as well as the extent and nature of the marketing business transacted; and (3) gross margins should be obtained for the principal commodities handled.

It is likely that the future success of the Association to a large extent will be determined by the degree to which it makes use of the information available and obtainable through financial records, and the efforts it makes to acquaint members and patrons with these facts.

\section{THE OPERATING AND FINANCIAL CONDITION OF COOPERATIVE FARM SERVICES}

In an attempt to analyze the operating and financial condition of Cooperative Farm Services, data were obtained concerning sales and commissions, gross income, operating expenses, net and total income, assets, and liabilities and net worth. Since the success or failure of the warehouse division has greater influence on the operating and financial condition of the Association than the success or failure of the purchasing division, special attention will be given in this section to the warehouse division.

The reader should be cautioned that the true picture of the financial and operating condition of Cooperative Farm Services as a whole cannot be obtained by separate consideration of data pertaining to either the warehouse or the purchasing divisions. Adequate data are not available for a detailed consideration of all operations of the Association. It is believed, however, that if the limitation of present data is kept in mind, the presentation of information relating to both purchasing and warehouse divisions will be helpful in acquainting directors and patrons of the Association with the nature and extent of its operations as well as some of the major problems with which it is confronted.

Separate balance sheets and operating expenses were obtained for the warehouse and purchasing divisions. Consolidated balance sheets and operating statements also were obtained for the Association as a whole. While data showng the volume of sales and purchases are available only for the warehouse division, some indication of the extent of the total business done by the Association can be gathered from examination of the total commissions collected by the purchasing division. Commissions are grouped according to four classes, namely: feed, seed, fertilizer, and general items. Total commissions collected are kept separately by classes of commodities handled.

As was indicated previously, no records are kept of the total purchases made through the purchasing division. Furthermore, no records are kept of the nature or extent of supplies obtained through the purchasing division of Cooperative Farm Services by the various distributive agencies. 


\section{Sales and Commissions}

Sales as reported by the warehouse division declined from $\$ 613,043$ in 1930 to $\$ 383,711$ in 1932 , or slightly over 40 percent. Sales have increased gradually since 1932, and 1937 reached an all-time high of $\$ 673,502$ (Table 11). The range in the value of products sold is accounted for partially by fluctuation in the general price level of farm supplies and partially by variations in the number of branch warehouses operated. The number of active warehouses has varied from as few as 12 in 1930 and 1935 to as many as 16 in 1931 and 14 during the period 1936-1938.

That the monthly distribution of sales as reported by the warehouse division fluctuates considerably is indicated by data given on page 35 . For the years 1935 through 1937, April has been the month of highest sales. The proportion of the annual business transacted in this month has varied from around 13 to 16 percent. While the amount of business transacted in .July and August usually was below the average, business activity was lowest in the months of November, December, January, and February when sales per month varicd between $41 / 2$ percent and 7 percent of the total annual business. (The sales policy is discussed on pp. 33 to 37.$)$

The commissions collected by the purchasing department are shown in Table 10. Commissions collected on feed declined significantly during the first three year's of operation. In 1930, feed commissions totaled $\$ 38,739$. This was nearly four times as much as the low of $\$ 10,427$ collected in 1935. Since 1935, commissions on feed have increased; in 1938 they amounted to $\$ 16,519$.

Fertilizer commissions have been nearly halved since 1933, varying from a high of $\$ 10,969$ in that year to a low of $\$ 5,730$ in 1937 .

Notable fluctuations have occurred with respect to commissions collected from seed, but no particular trend has been discernible. Commissions have ranged from $\$ 1,406$ in 1932 to $\$ 4,546$ in 1934 . In 1938 , seed commissions totaled $\$ 3,216$.

Commissions collected on general items have increased as new items have been added. They range from a low of $\$ 5,010$ in 1931 to a high of $\$ 7,818$ in 1938. Increases in 1937 and 1938 are largely attributable to the addition of electrical equipment. Except for important declines in feed commissions during the first two years of operation, little significant variation has occurred in the amount of commissions collected. Since no records are kept of commissions paid by the various distributive agencies, no measure is available relative to the extent and nature of the supplies these agencies handle (Table 10).

\section{Operating Efficiency}

Consolidated operating statements for Cooperative Farm Services and for the purchasing and warehouse divisions are shown in Table 11. Detailed operating statements are given in the Appendix-Tables A-I, A-II, and A-III. With respect to the consolidated statements. gross operating income includes the operating income of the warehouse division 


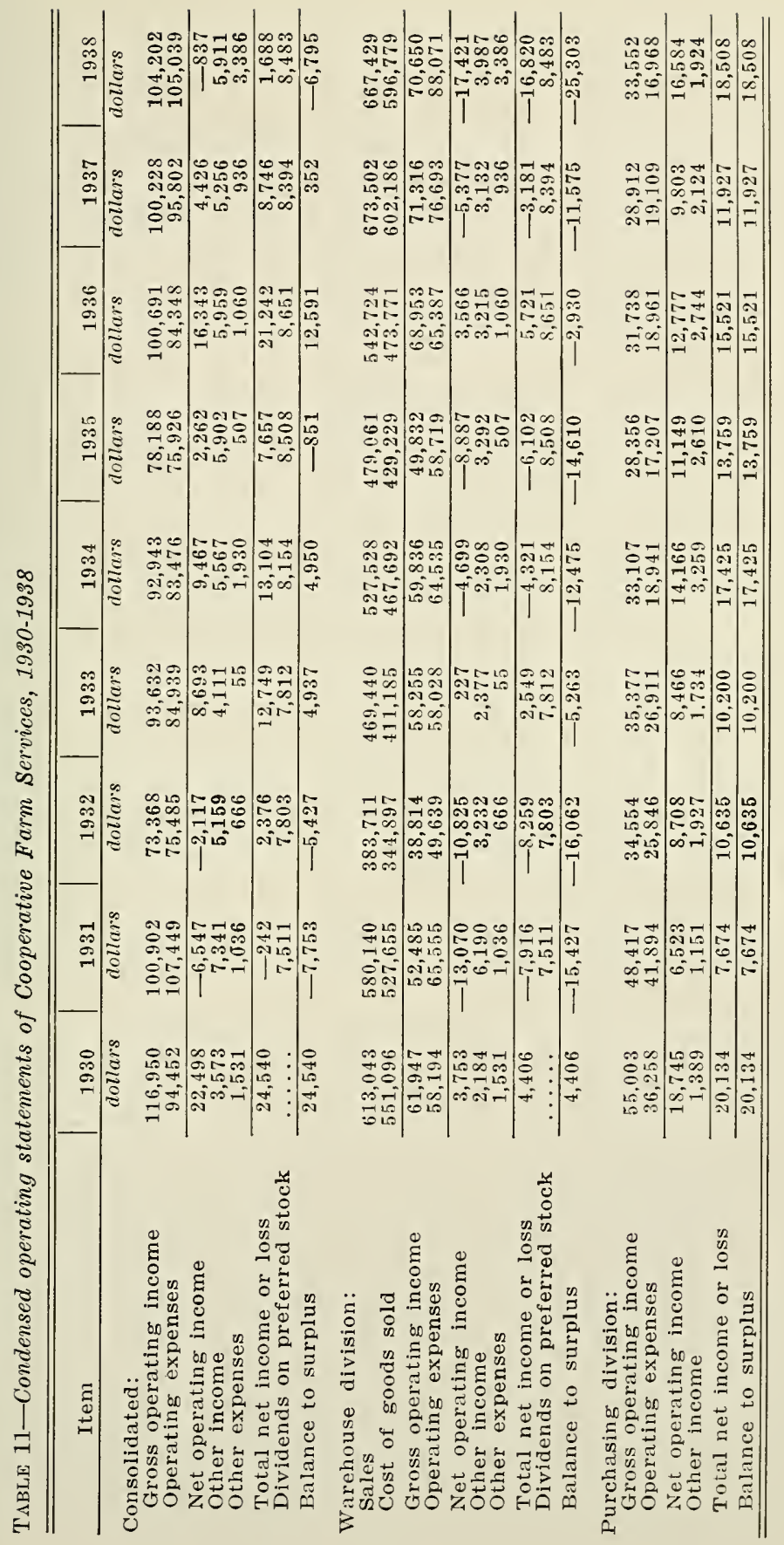


and all commissions collected by the purchasing division. Of all gross income in 1938, 32.2 percent was from commissions of the purchasing division; and 67.8 percent from receipts of the warehouse division. This is in contrast with 1930 , when the proportion was 47 percent and 53 percent respectively. In 1938 the gross operating income for the purchasing division was $\$ 33,552$ as compared with $\$ 55,003$ in 1930 . This is in contrast with the warehouse division, which reported a gross operating income of $\$ 61,947$ in 1930 and $\$ 70,650$ in 1938. Expressed in terms of percentage of sales, gross operating income for the warehouse division has varied from a low of 9 percent in 1931 to a high of 12.7 percent in 1936. In 1938 it was 10.6 percent.

Operating expenses reported by the Cooperative Farm Services have ranged from $\$ 75,485$ in 1932 to $\$ 107,449$ in 1931 . In 1938 this item totaled $\$ 105,039$. Fixpenses for the warehouse department have increased from a low of $\$ 49,639$ in 1932 to an all-time high of $\$ 88,071$ in 1938 . Operating expenses of the warehonse department, expressed on a percentage of sales basis, have increased from a low of 9.5 percent in 1930 to a high of 13.2 percent by 1938. During the seven-year period 1932 1938 this item has averaged between 11.4 and 13.2 percent of annual sales. In contrast, operating expenses of the purchasing department have declined approximately 50 percent or from $\$ 36,258$ in 1930 to $\$ 16,968$ in 1938.

The warehouse division has operated at a net operating loss during six of its nine years of operation. During three years, losses have been over $\$ 10,000$ annually and for the three remaining years losses have ranged from $\$ 4,699$ to $\$ 8,887$. In 1938 , operating losses totaled $\$ 17,421$, an all-time high. This is equivalent to a loss of 2.6 cents on each dollar of sales. Losses were between 2 percent and 3 percent of sales for three years, and under 2 percent for three years. During the three years that the warehouse division has shown an operating income, this item has averaged about $\$ 2,500$ per year.

During three years out of nine, the Association has experienced a net operating loss varying in amount from $\$ 837$ in 1938 to $\$ 6,547$ in 1931 . The purchasing department has shown a relatively satisfactory position with respect to net operating income. This item has been over $\$ 15,000$ for two year's, between $\$ 10,000$ and $\$ 15,000$ for three years, and between $\$ 5,000$ and $\$ 10,000$ for four years. For the nine-year period, net operating income averaged 32.5 percent of the gross operating income, or a sum equal to 48.1 percent of all expenses. Since the purchasing division operates largely on a commission basis, there is no possibility of experiencing losses because of fluctuations in the general price level or because of bad accounts.

Other income as reported for the warehouse and purchasing divisions of Cooperative Farm Services consisted primarily of interest received and discounts taken. Discounts on orders were granted by various dealers to the purchasing division. Commissions received were primarily a warehouse division item and were derived from the sale of agricultural 
products and from the patronage dividends on fertilizer paid by the purchasing division.

Other expenses consist primarily of interest on borrowed funds. In 1938 this item also included a discount of $\$ 1,858$ to Farm Bureau members on the eash purchase of supplies.

Since returns from other income exceeded other expenses, the net income or loss statement of the Association showed to somewhat better advantage than the net operating income or loss figures, although the same general relationship prevailed. It has been mentioned that the Association is obligated to pay a 6 percent dividend on the preferred stock held by the warehouse department. The term "Balance to Surplus"19 is used to describe the financial condition of the Association after interest on preferred stock has been deducted from net income or loss. While the Association has followed the practice of deducting preferred stock dividends from the net income of the purchasing division, this practice is subject to the shortcoming of charging all distributive agencies for this item whether or not they purchased through the warehouse division. After making allowance for this change, it will be noted that the operations of the warehouse division resulted in a deduction from the surplus account during the last eight years of operation. These losses exceeded $\$ 15,000$ for three years, and in 1938 reached an all-time high of $\$ 25,303$. During three years losses were between $\$ 10,000$ and $\$ 15,000$, and for two years this item averaged under $\$ 10,000$. For the Association as a whole, these losses were experienced during four years out of nine.

The operating expenses incurred by Cooperative Farm Services for 1938 are given in condensed form in Table 12. The percentage distribution of consolidated operating expenses for the nine-year period 1930 1938 is shown in Table 13. Since the value of the products handled through the Association is kept only for the warehouse division, the various operating expenses are expressed as a part of the total operating expenses only, and are not in terms of sales.

While noticeable variations occur, no significant trends seem dis. cernible. This is especially true with respect to the purchasing department. Such items as wages, bonuses, salaries and commissions, and general expense accounted for about 80 percent of operating expenses from year to year.

With respect to the warehouse division, rents, taxes, and insuranec. as well as general expenses, have shown a tendency to increase slightly; bad accounts arc reported as less; other items do not indicate any particular trend. For the Association as a whole, four items-(1) wages, bonuses, salaries, and commissions; (2) office expenses; (3) general expenses; and $\because \neq$ rent, taxes, and insurance-constitute about 80 percent of all orerating expenses. In 1938, for example, wages comprised 41.8 perrent, and the other items 13.0 percent, 12.3 percent, and 14.5 percent respectively.

The operating ratios presented in Table 14 sili be helpful in evalu-

${ }^{19}$ This item ivas obtained by deducting patronage dividends from the yearly net income or inss of the warehouse division. 


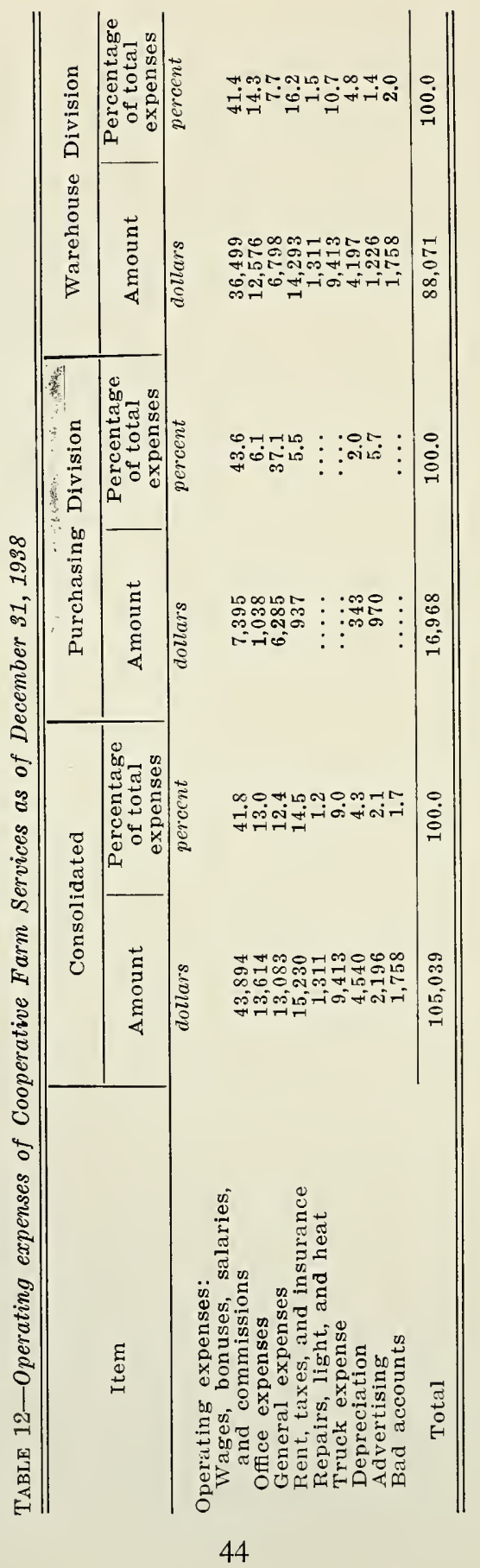




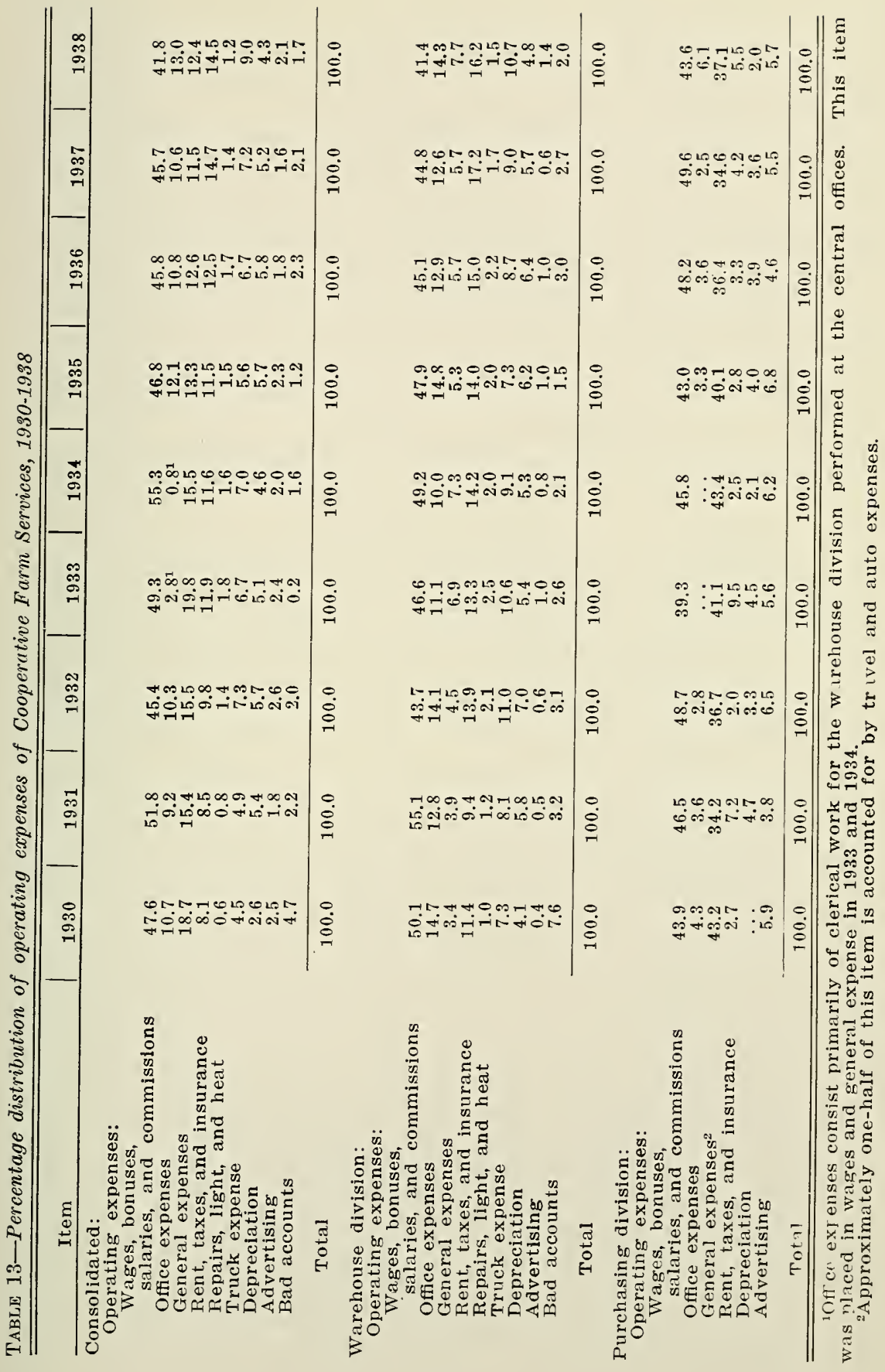




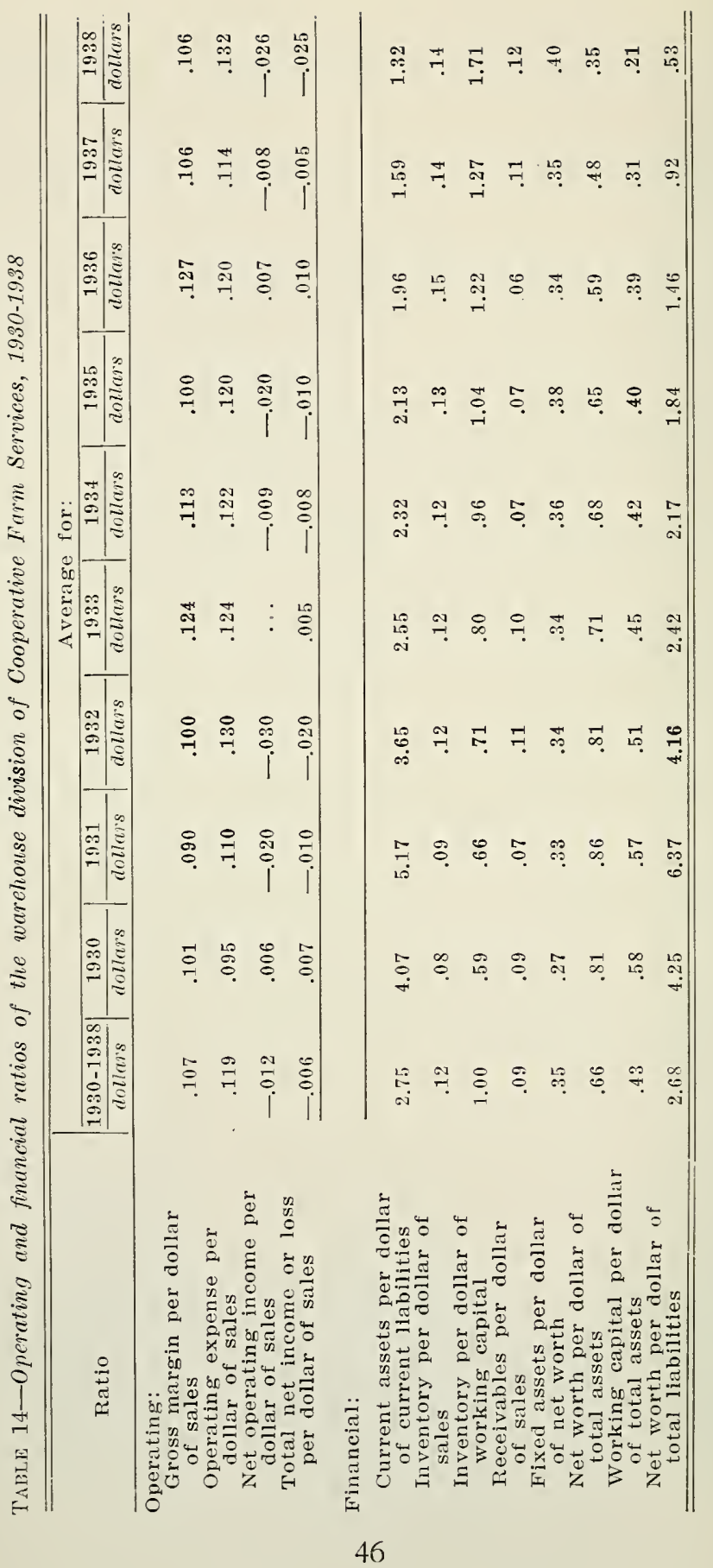


ating the present operating position of the warehouse division. Examination of these ratios leads to the following observations:

(1) Gross margins have shown no particular trend, varying from 9 cents per dollar of sales in 1931 to 12.7 cents per dollar of sales in 1936 . This means that the warehouse division may have an opportunity to improve its bargaining position in buying farm supplies and may be able to bring about increased efficiencies in operation.

(2) The trend in operating expenses on a per-dollar-of-sales basis has been upward. The cost of doing business has increased approximately 40 percent during nine years of business operation, or from 9.5 cents per dollar of sales in 1930 to 13.2 cents per dollar of sales in 1938 .

(3) Trends in operating income per dollar of sales have been downward and suggest the necessity for increasing efficiency in the operation of the warehouse division.

(4) The ratio of total net income or loss per dollar of sales indicates that the warehouse division has an opportunity to increase savings on the business transacted.

\section{Financial Condition}

Consolidated balance sheets as of December 31, 1930-1938, for Cooperative Farm Services are shown in Table 15. Detailed balance sheets are presented in the Appendix-Tables A-IV, A-V, and A-VI. For comparative purposes it was necessary to revise the balance sheets set up by the Association. Assets were classified as current, fixed, and other assets. Liabilities were divided into liabilities and net worth. Furthermore, interdepartmental accounts were canceled in the revised balance sheets set up for this study.

Total assets of the Association have increased from $\$ 186,560$ in 1930 to $\$ 223,526$ in 1938 . In that year current assets comprised 81.5 percent of total assets, fixed assets were 17 percent, and other assets 1.5 percent. These figures differ but slightly from those for 1930, which indicates that current assets amounted to 79.6 percent of total assets, fixed assets were 19.2 percent, and other assets 1.2 percent.

The proportion that current assets are of total assets has varied from 73.4 percent in 1934 to 81.5 percent in 1938 . Significant changes, however, have occurred with respect to the various items comprising current assets during the nine vear period 1930-1938 (Table A-IV). For example, cash has declined from a high of $\$ 29,765$ in 1930 to a low of $\$ 3,423$ by 1938 . This represents a decline from 16 percent of total assets to 1.5 percent. Receivables have decreased from $\$ 68,516$ in 1930 to $\$ 45$,631 in 1935 , only to increase to $\$ 86,776$ in 1938 . Expressed on a percentage basis, receivables comprised 36.7 percent of all assets in 1930,26 percent in 1935 , and 38.8 percent in 1938. Inventories have increased appreciably since 1933 and in 1938 totaled $\$ 92,120$. This represents an increase from 26.9 percent of total assets in 1930 to 41.2 percent in 1938 (compiled from Table A-IV).

Examination of Table 15 indicates some rather unusual items. While the warehouse division in 1938 is credited with cash totaling $\$ 47$,- 
883 , the total for the association is listed at only $\$ 3,423$. This situation is accounted for by the fact that many of the branch warehouses draw on the general reserve of the purchasing division and as a result have more cash at their disposal than is shown in the consolidated statement for both divisions. Since the consolidated statement cancels out many of the interdepartmental operations, notable differences also exist with regard to various receivable and payable items. Because some of the preferred stock of the warehouse division was re-acquired by the purchasing division, the figures given for these items are not necessarily the same as those given in the consolidated balance sheets in Table 15.

Examination of the liability and net-worth items shows that liabilities have become a significant item only during the past two years. All liabilities are in the form of current liabilities, and in 1938 they totaled $\$ 43,871$, or 19.6 percent of all liabilities and net worth. The net-worth item of the association, which is represented primarily by preferred stock, has shown little change during nine years of operation. Net worth totaled $\$ 163,755$ in 1930 and reached an all-time high of $\$ 195,512$ in 1937 (Table 15).

Total assets of the warehouse division were listed at $\$ 256,300$ in 1938. Of this amount 85.9 percent is reported as current assets, 13.8 percent as fixed assets, and 0.3 percent as other items (Table 15). Inventories constitute 35.5 percent of all the assets, receivables 31.7 percent, and cash 18.7 percent (compiled from Table A-V). The only other important item listed as fixed assets was real estate and buildings which comprise 11 percent of total assets. The Association reports that the original cost of fixed assets was $\$ 59,476$ and that depreciation on buildings, fixtures and equipment, and delivery equipment is carried at $\$ 21$,590. Since most of the warehouses operated by the Association are rented, investments in real estate and buildings are relatively low. In 1938 net worth comprised 34.8 percent of the liabilities and net-worth account. Accounts payable, due the purchasing department, amounted to $\$ 156,610$ and accounted for 61.1 percent of all liabilities (Table A-V).

Examination of the trend of various items included in liabilities and net worth for the warehouse division is indicative of trends in the financial condition of the Association. For example, accounts payable have increased from $\$ 18,706$ in 1930 to a high of $\$ 156,610$ in 1938 or from 12.9 percent to 61.1 percent of all liabilities and net worth; preferred stock has increased from $\$ 116,366$ to $\$ 149,055$ during the same period. (Table A-V).

In 1930, total assets of the purchasing division of Cooperative Farm Services totaled $\$ 47,038$ and in 1938 this item had increased to $\$ 98,237$. Current assets have comprised between 85 and 95 percent of all assets (Table 15). Cash, however, has declined from $\$ 28,355$ in 1931 to $\$ 3,423$ in 1938. Accounts receivable primarily represent accounts of the warehouse division of the Association. They have increased eightfold, or from $\$ 9,967$ in 1930 to $\$ 79,353$ in 1938 (See Table A-VI).

Net worth comprises the greatest share of all items included in the liability and net-worth statement. While practically no change has taken place in the amount of common stock held, or in the dividends payable 


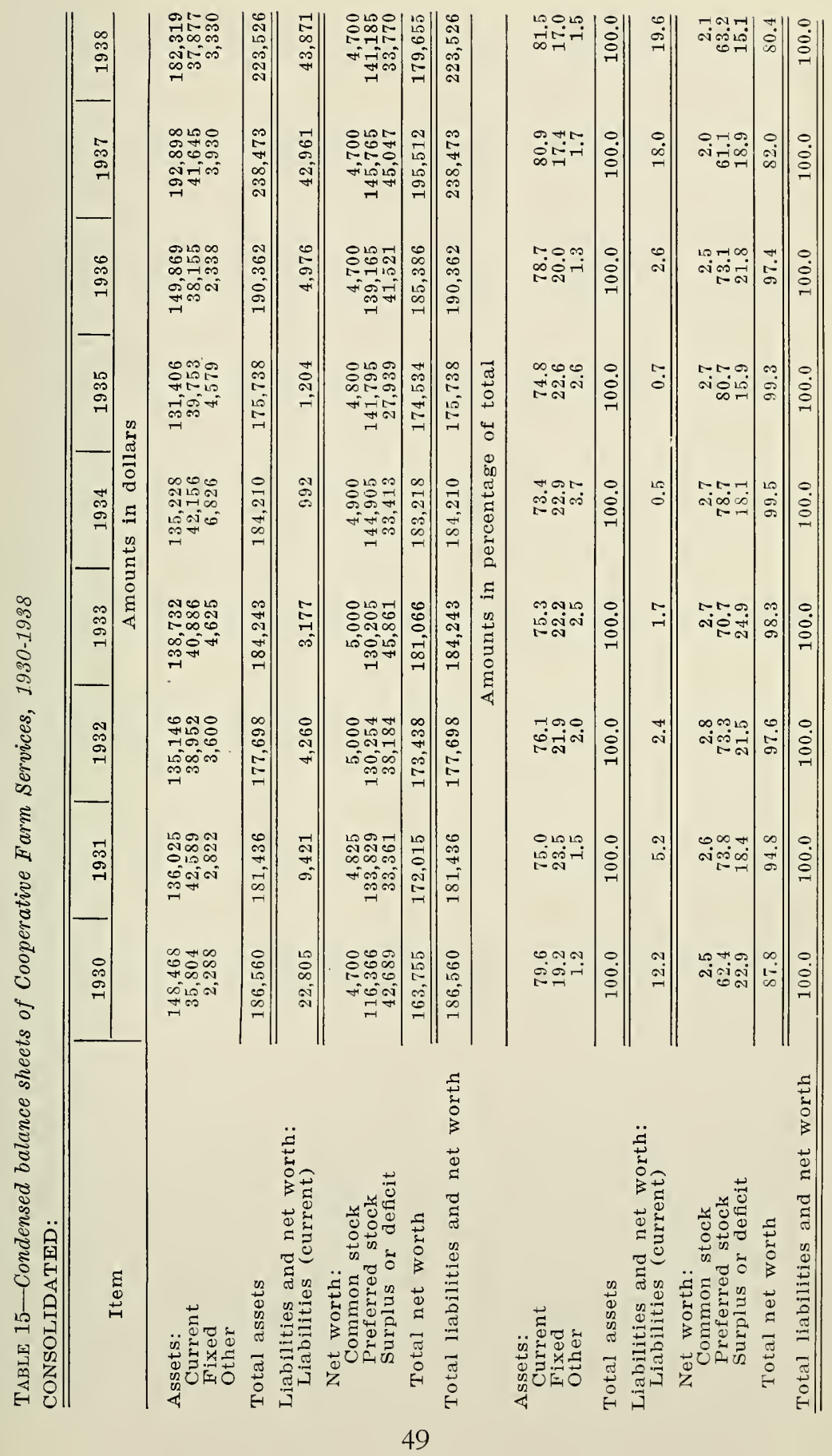




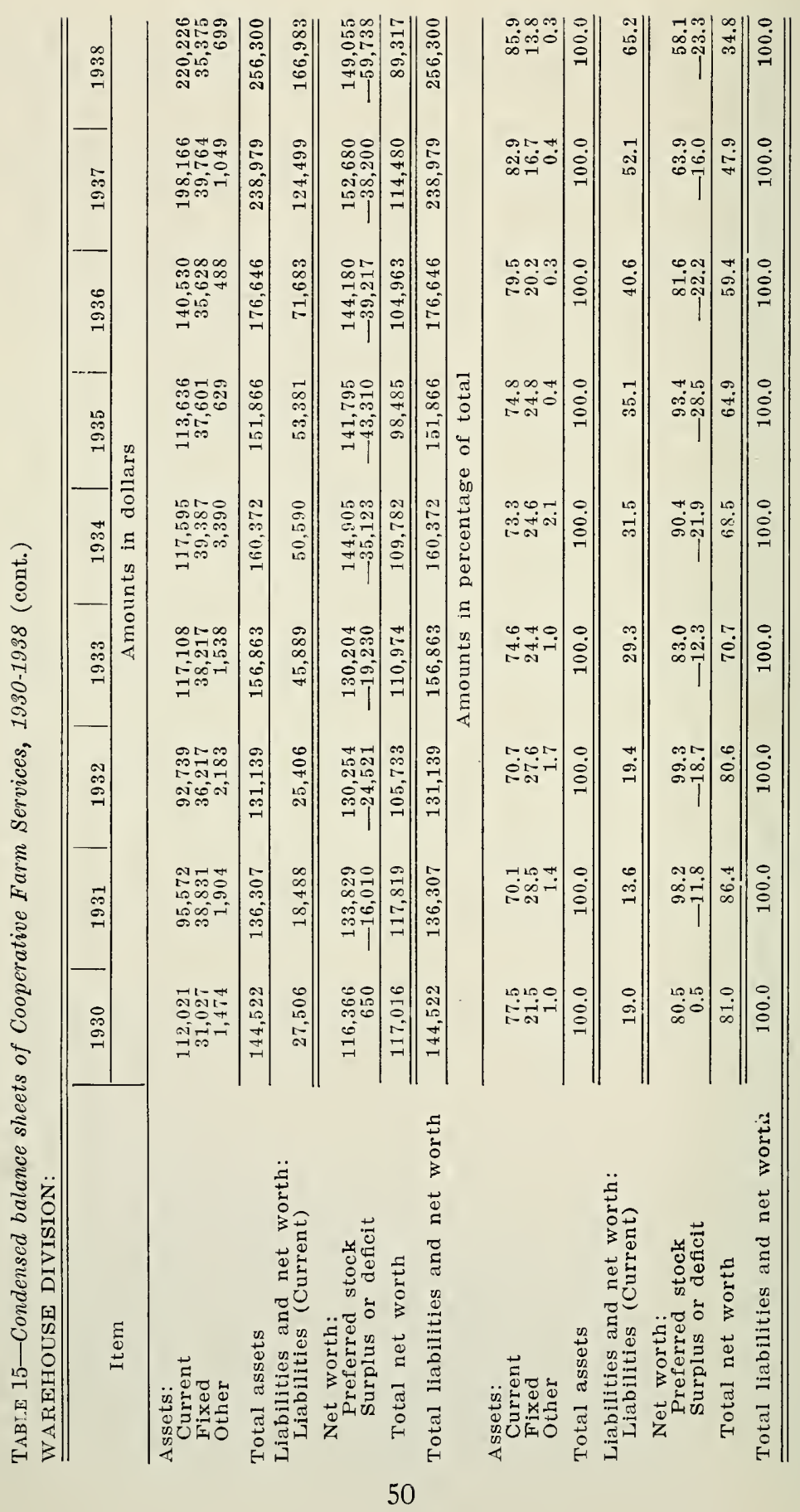




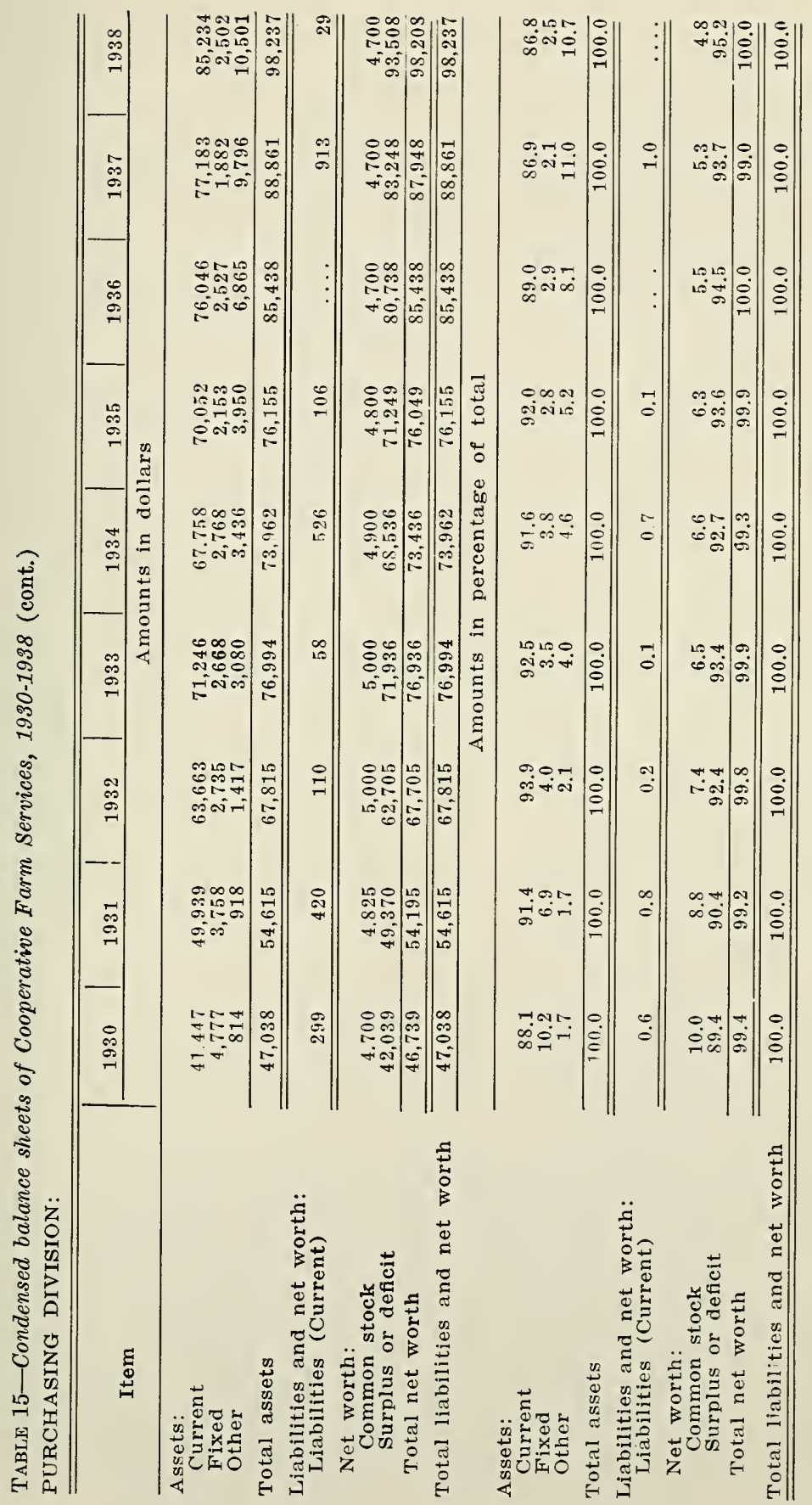


on preferred stock, increases in liabilities and net worth have been due to the growth of the surplus item from $\$ 42,039$ in 1930 to $\$ 93,508$ in 1938 (Table 15).

The financial ratios presented in Table 14 will be useful as a means of indicating trends in, and the status of, the financial position of the warehouse division. The following observations seem significant:

(1) The decline in the ratio of current assets per dollar of current liabilities from $\$ 4.07$ in 1930 to $\$ 1.32$ in 1938 indicates a decline in the liquidity of the Association.

(2) Inventory per dollar sales has increased from around 8 to 14 cents during the nine-year period. This suggests the desirability of eliminating slow-moving items in order to improve the inventory position of the Association.

(3) No significant trend seems to exist with respect to receivables per dollar of sales, although an all-time high was reached in 1938 . The Association has maintained this item below 15 cents to the dollar.

(4) A decrease in working capital combined with an increase in inventory per dollar of sales has resulted in an increased proportion of capital being tied up in inventories. Inventory per dollar of working capital was $\$ .59$ in 1930 and $\$ 1.71$ in 1938 - a threefold increase.

(5) Fixed assets per dollar of net worth have increased from 27 cents in 1930 to 40 cents in 1938. This is evidence of an increasing tendency to tie up investors' funds in long-time obligations.

(6) The trend in the ratio of net worth per dollar of total assets indicates a very significant decline in the stockholders' equity in the Association. Net worth per dollar of total assets was 81 cents in 1930 and 35 cents in 1938.

(7) The decline in working capital per dollar of total assets from 58 cents in 1930 to 21 cents in 1938 indicates that the greater proportion of the Association's funds are tied up in fixed assets, while working capital has declined.

(8) Examination of the ratio of net worth per dollar of liabilities, likewise, indicates a decrease in net worth as compared with liabilities. This ratio declined from $1: 4.25$ in 1930 to $1: 0.53$ in 1938 .

The foregoing considerations show that it would be to the advantage of the warehouse division to give immediate attention to improving operating efficiency.

\section{LOCAL WAREHOUSE OPERATIONS}

Until recently all the warehouses of Cooperative Farm Services were operated on a centralized basis as branch units of the warehouse division of the Association. As a result, general operating and financial_policies are much the same for all warehouses. Comparison of warehouse operations under these conditions will serve to give a better measure of the operating practices established than could be obtained if warehouses were operated as independent units. However, the findings of this section may be used as measures of operating efficiency by all local warehouses, whether operated as branch units of a centralized association or as local federated associations. 
With the assistance of the manager of Cooperative Farm Services, branch warehouses were classified as "good" and "poor." While it is recognized that such a classification is more or less arbitrary, careful consideration was given to such factors as relative operating efficiency, financial condition, services rendered, and the volume of business transacted. It is believed that this basis of classification offers a more satisfactory means of selecting warehouses for comparison than does classification according to statistical factors only. Various selected operating and financial ratios, along with volume of business, do not in themselves give a complete picture of the effectiveness with which various establishments furnish farmers with supplies.

It also must be kept in mind that distinct differences occur in the operating condition of various branch warehouses. For example, it has been indicated that some warehouses handle limited amounts of groceries; others omit them altogether. Some warehouses purchase and market small amounts of agricultural products; others restrict business entirely to supplies. Two warehouses sell gasoline; the others do not. In short, the extent and the nature of products handled by individual establishments differ appreciably.

It is quite likely that the financial condition of branch warehouse units offer fewer significant possibilities for comparison of financial data than are offered by independently incorporated warehouse associations. It is also true that many of the state and regional farm-supply associations are in position to exercise strict control over local warehouses. Under these conditions operating margins may be smaller, and financial ratios need not indicate as strong a surplus and net-worth status as is necessary for independent units. In spite of modifying influences, however, it is believed that comparison of good and poor warehouses will serve to indicate significant differences in financial and operating conditions and may suggest wavs in which operating efficiency may be improved.

\section{Operating Practices}

Average condensed operating statements for all active branch warehouse units and for the six good and the six poor warehouses of Cooperative Farm Services for 1928 are shown in Table $16 .^{20}$ Significant differences will be noted. For example, sales averaged $\$ 63.548$ for the good warehouses and $\$ 34,365$ for the poor ones. Gross margins were 9.6 cents per dollar of sales for the good as contrasted with 12.1 cents for the poor ones. Expenses averaged 11.8 cents per dollar of sales for the good establishments as compared with 16 cents for the poor ones.

The relationship of the average operating expenses is shown in the operating ratios presented in Table 17 . The fact that gross margins for the poor warehouses are one-fourth higher than for the good warehouses

${ }^{20}$ Some of the data pertaining to operating and financial practices of the branch warehouse units of Cooperative Farm Services presented in Tables $16,17$. 20 , and 21 of this section are not identical with similar items presented for the warehouse division of the Association in the section on operating and financial condition. This situation exists because the warehouse division carries some items for two branch warehouses no longer actively engaged in the distribution of farm supplies. 


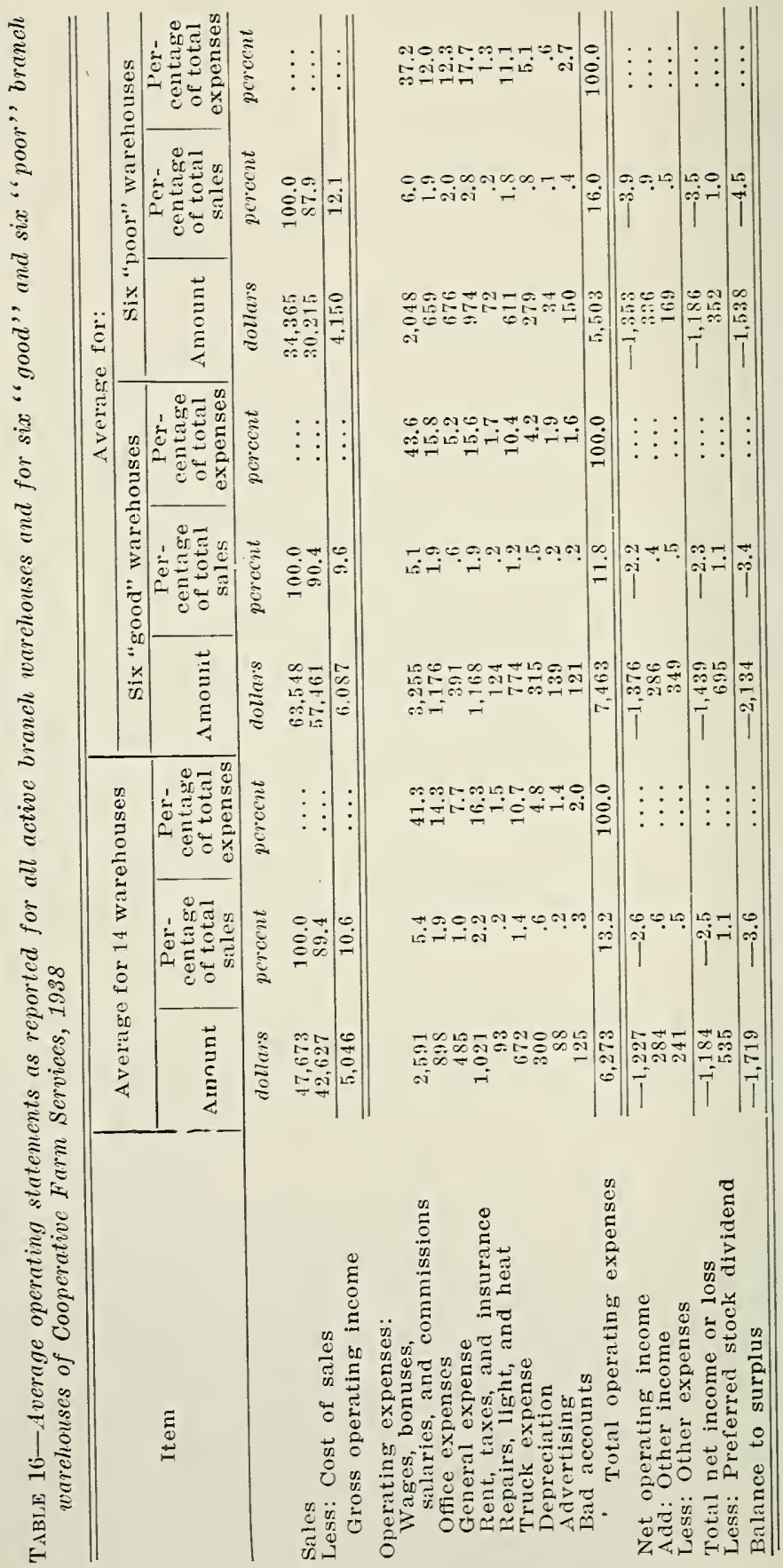


is accounted for in part by the fact that competition is more aggressive in the trading areas serviced by the larger warehouses. It is not indicative, in this instance, of the ability of the good warehouses to purchase supplies to greater advantage.

This conclusion is also substantiated by examination of the net income and loss items (Table 16). It will be noted that net income in 1938 was -2.5 percent of sales for all branch warehouses, -2.3 percent for good ones, and -3.5 percent for poor ones. When allowance is made for the payment of interest on preferred stock, warehouse operations resulted in a deduction from the surplus account of Cooperative Farm Services of 3.6 percent of sales for all branch warehouses, 3.4 percent of sales for relatively good ones, and 4.5 percent of sales for poor ones. It is also significant that for the period July 1, 1937, to July 1, 1939, credit sales

TABLE 17-Average operating ratios for all active branch warehouses and for six "good" and six "poor" branch warehouses of Cooperative Farm Services, 1938

\begin{tabular}{|c|c|c|c|}
\hline Ratio & $\begin{array}{l}\text { Average for } \\
\text { fourteen } \\
\text { warehouses }\end{array}$ & $\begin{array}{l}\text { A verage for } \\
\text { six "good" } \\
\text { warehouses }\end{array}$ & $\begin{array}{c}\text { Average for } \\
\text { six "poor" } \\
\text { warehouses }\end{array}$ \\
\hline Operating: & dollars & dollans & dollars \\
\hline $\begin{array}{l}\text { Gross margin per dollar } \\
\text { of sales }\end{array}$ & $\cdot .106$ & .096 & .121 \\
\hline Operating expense ner & & & \\
\hline $\begin{array}{l}\text { dollar of sales } \\
\text { Net operating income }\end{array}$ & . 132 & .118 & .160 \\
\hline per dollar of sales & -.026 & -.022 & -.039 \\
\hline $\begin{array}{l}\text { Total net income or loss } \\
\text { per dollar of sales }\end{array}$ & -.025 & -.023 & -.035 \\
\hline \multirow{9}{*}{$\begin{array}{l}\text { Financial: } \\
\text { Current assets per dollar } \\
\text { of current liabilities } \\
\text { Inventory per dollar of } \\
\text { sales } \\
\text { Inventory per dollar of } \\
\text { working capital } \\
\text { Receivables per dollar } \\
\text { of sales } \\
\text { Fixed assets per dollar of } \\
\text { net worth } \\
\text { Net worth per dollar of } \\
\text { total assets } \\
\text { Working capital per aollar } \\
\text { of total assets } \\
\text { Net worth per dollar of } \\
\text { total liabilities }\end{array}$} & & & \\
\hline & 1.35 & 1.49 & 1.10 \\
\hline & .14 & .13 & .16 \\
\hline & 1.74 & 1.45 & 5.01 \\
\hline & .11 & .10 & .14 \\
\hline & .39 & .37 & .47 \\
\hline & .37 & .44 & $.1 €$ \\
\hline & .22 & $.2 \varepsilon$ & .08 \\
\hline & .59 & .78 & .20 \\
\hline
\end{tabular}

averaged 31.2 percent of all sales for good warehouses and 53.1 percent for poor ones. This fact also helps to explain why losses from bad debts are twice as high for poor warehouses as for good ones. It also suggests that any efforts made to increase or maintain patronage of the poorer warehouses by relaxing credit policies tends to result in higher costs of operation. Bad accounts, depreciation, rent, truck expense, wages, and electric shop expense are the more important items accounting for the increased operating expenses of the poor branch warehouses.

Since efficiency of operation and ability to attain a satisfactory net income are usually considered to be rather closely associated with the volume of business transacted, average operating statements were prepared for branch warehouses classified on the basis of size. Warehouses were classified into three groups-large, medium, and small. 


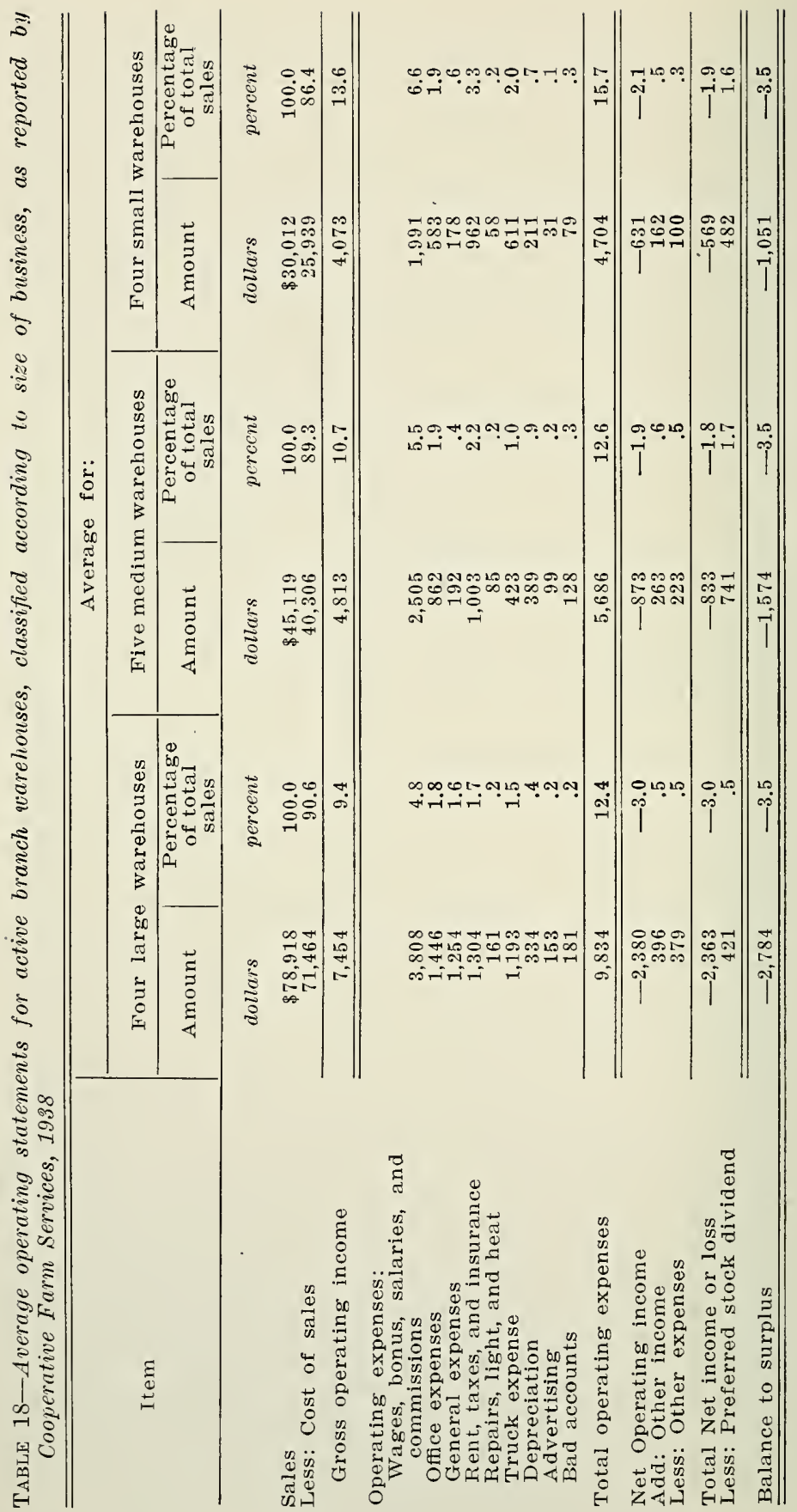


Average condensed operating statements for these classifications for 1938 (Table 18) furnish significant comparisons. Sales were $\$ 78,918$ for the large warehouses, $\$ 45,119$ for the medium ones, and $\$ 30,012$ for the small ones. Gross margins and operating expenses per dollar of sales were relatively similar for the large and medium warehouses, but considerably higher for the small warehouses.

Examination of operating expenses indicates that such items as wages, rent, and truck expense become greater on a per-dollar-of-sales basis as the amount of business transacted decreases. The results of lower gross margins for the larger warehouses are reflected in a net income of -3.0 percent of sales for the larger warehouses and only -1.8 percent and -1.9 percent of sales respectively for the medium and small warehouses. These data indicate that the larger establishments are faced with the necessity of obtaining higher gross margins if they are to avoid operating at the highest net loss.

Since only three of the large warehouses and three of the small warehouses are financed directly with preferred stock sold in the county in which the branch warehouse units operate, interest charges for this item are relatively less for the large and small warehouses. Indications are, however, that interest charges on preferred stock for the warehouses financed by this method are relatively greater for the smaller establishments. It is interesting to note that after deductions are made for interest charges, all thrce classes operated at a loss of 3.5 cents per dollar of sales.

Distribution of branch warehouses according to selected operating comparisons for the nine-year period $1930-1938$ is given in Table 19. While the general trend in distribution of the warehouses is in accordance with the trends observed for the warehouse division (see page 52), significant variations prevail for individual warehouses. For example, about three-fifths of all warehouses operated with a gross income of less than 10 percent of sales during the first three years of operation, and only one-fourth did so during the three-year period 1936-1938. Likewise one warehouse out of eight operated at a gross margin in excess of 12 percent of sales during the first period, and during the last period this proportion had increased to two warehouses out of five. Similar trends exist with respect to operating expenses. Two warehouses out of five showed a net income in percentage of sales during the first three years of operation, but only one out of five did so during the last three.

Since salaries on the average account for about two-fifths of all operating expenses, they are the most important expense item. Distribution of salaries in terms of percentage of sales is also presented. While no particular trends are discernible in this item, it is significant that it accounts for 5 to 7 percent of sales for many warehouses (Table 19).

\section{Financial Condition}

Comparison of average balance sheets for all active branch warehouses and for the six good and the six poor warehouses of Cooperative Farm Services for 1938 is given in Table 20. Assets averaged $\$ 16,702$ for all warehouses, $\$ 20,217$ for the good ones, and $\$ 13,208$ for the pooi 
ones. Current assets averaged 85.1 percent of all assets, 83.7 percent, and 91.9 percent, respectively. Variations in current assets primarily are caused by lower receivable items for the good warehouses than for the poor ones (31.6\% of all assets as compared with $37.4 \%)$. Good warehouses also had higher investments in real estate, primarily because a greater number of the warehouses were owned. This item amounted to 13.5 percent of all assets for the good warehouses and to only 4.1 percent for the poor ones.

TABLE 19-Distribution of branch warehouses according to selected operating comparisons, 1930-1938

\begin{tabular}{c|c|c|c|c|c|c|c|}
\hline \\
Operating comparison & $\frac{\text { Years of operation }}{1930}|1931| 1932|1933| 1934|1935| 1936|1937| 1938$ \\
\cline { 2 - 3 }
\end{tabular}

Gross income as percentage

of sales:

Under 8 percent

8 to 10 percent

10 to 12 percent

12 to 14 percent

14 percent and over

Total

\begin{tabular}{rrrrrrrrr}
2 & 5 & 2 & 2 & 2 & $\cdots$ & $\ldots$ & $\cdots$ & 2 \\
5 & 7 & 4 & $\cdots$ & 1 & 6 & $\cdots$ & 6 & 3 \\
3 & 2 & 6 & 3 & 5 & 3 & 5 & 5 & 5 \\
2 & 2 & 1 & 3 & 3 & 2 & 6 & 2 & 2 \\
$\ldots$ & $\ldots$ & $\ldots$ & 5 & 2 & 1 & 3 & 1 & 2 \\
\hline 12 & 16 & 13 & 13 & 13 & 12 & 14 & 14 & 14 \\
\hline
\end{tabular}

Operating expense as percentage of sales:

Under 8 percent

8 to 10 percent

10 to 12 percent

12 to 14 percent

14 to 16 percent

16 percent and over

Total

\begin{tabular}{|c|c|c|c|c|c|c|c|c|}
\hline $\begin{array}{r}5 \\
3 \\
2 \\
1 \\
\cdots\end{array}$ & $\begin{array}{l}4 \\
4 \\
3 \\
2 \\
3\end{array}$ & $\begin{array}{l}\cdots \\
\cdots \\
5 \\
3 \\
1\end{array}$ & $\begin{array}{l}2 \\
2 \\
3 \\
5 \\
1 \\
2\end{array}$ & $\begin{array}{r}1 \\
1 \\
5 \\
5 \\
1 \\
1\end{array}$ & $\begin{array}{r}2 \\
2 \\
5 \\
5 \\
3 \\
\end{array}$ & $\begin{array}{r}1 \\
7 \\
4 \\
2\end{array}$ & $\begin{array}{r}- \\
3 \\
6 \\
3 \\
2 \\
\ldots\end{array}$ & $\begin{array}{r}3 \\
3 \\
2 \\
4 \\
4\end{array}$ \\
\hline 12 & 16 & 13 & 13 & 13 & 12 & 14 & 14 & 14 \\
\hline
\end{tabular}

Net income as percentage of sales:

-8 percent and nnder

-6 to -8 percent

-4 to -6 percent

-2 to -4 percent

0 to -2 percent

0 to 2 percent

2 to 4 percent

4 percent and over

Total

\begin{tabular}{|c|c|c|c|c|c|c|c|c|}
\hline & 2 & $\because$ & $\cdots$ & 1 & $\because$ & 1 & $\cdots$ & 1 \\
\hline 1 & 1 & 1 & $\ldots$ & $\cdots$ & 1 & $\cdots$ & 2 & 2 \\
\hline & 1 & 2 & . & 2 & 1 & 1 & 1 & 1 \\
\hline 1 & 1 & 3 & 2 & 4 & 6 & $\because$ & 2 & 3 \\
\hline 1 & 7 & 4 & 5 & 4 & 4 & 5 & 6 & 5 \\
\hline 7 & 4 & 3 & 1 & 1 & $\cdots$ & 7 & 3 & 2 \\
\hline 2 & $\cdots$ & $\cdots$ & 4 & 1 & $\cdots$ & . & $\cdots$ & $\cdots$ \\
\hline$\cdots$ & $\cdots$ & $\cdots$ & 1 & $\cdots$ & $\cdots$ & $\cdots$ & $\cdots$ & $\cdots$ \\
\hline 12 & 16 & 13 & 13 & 13 & 12 & 14 & 14 & 14 \\
\hline
\end{tabular}

Salaries, bonuses, wages, and commissions as percentage of sales:

\begin{tabular}{|c|c|c|c|c|c|c|c|c|c|}
\hline $\begin{array}{l}\text { Under } 4 \text { percent } \\
4 \text { to } 5 \text { percent } \\
5 \text { to } 6 \text { percent } \\
6 \text { to } 7 \text { percent } \\
7 \text { percent and over }\end{array}$ & $\begin{array}{r}2 \\
5 \\
4 \\
1 \\
\cdots\end{array}$ & $\begin{array}{l}3 \\
2 \\
3 \\
4 \\
7\end{array}$ & $\begin{array}{r}\dot{2} \\
7 \\
4 \\
\ldots\end{array}$ & $\begin{array}{l}1 \\
1 \\
4 \\
7 \\
.\end{array}$ & $\begin{array}{r} \\
1 \\
5 \\
7 \\
\ldots\end{array}$ & $\begin{array}{r}0 \\
2 \\
3 \\
7 \\
\ldots\end{array}$ & $\begin{array}{l}3 \\
2 \\
9 \\
1 \\
2\end{array}$ & $\begin{array}{l}1 \\
5 \\
6 \\
1 \\
1\end{array}$ & $\begin{array}{l}1 \\
4 \\
3 \\
5 \\
1\end{array}$ \\
\hline Total & 12 & 16 & 13 & 13 & 13 & 12 & 14 & 14 & 14 \\
\hline
\end{tabular}

More significant relationships exist with respect to liabilities and net-worth items. Current liabilities comprise 56.1 percent of all liabilities and net worth for the good warehouses and 83.6 percent for the poor ones. Accounts, notes, and loans payable accounted for practically all liabilities. Preferred stock accounted for 57.3 percent of all liabilities and net worth of the good warehouses, and 44.5 percent of these items for the poor ones. 


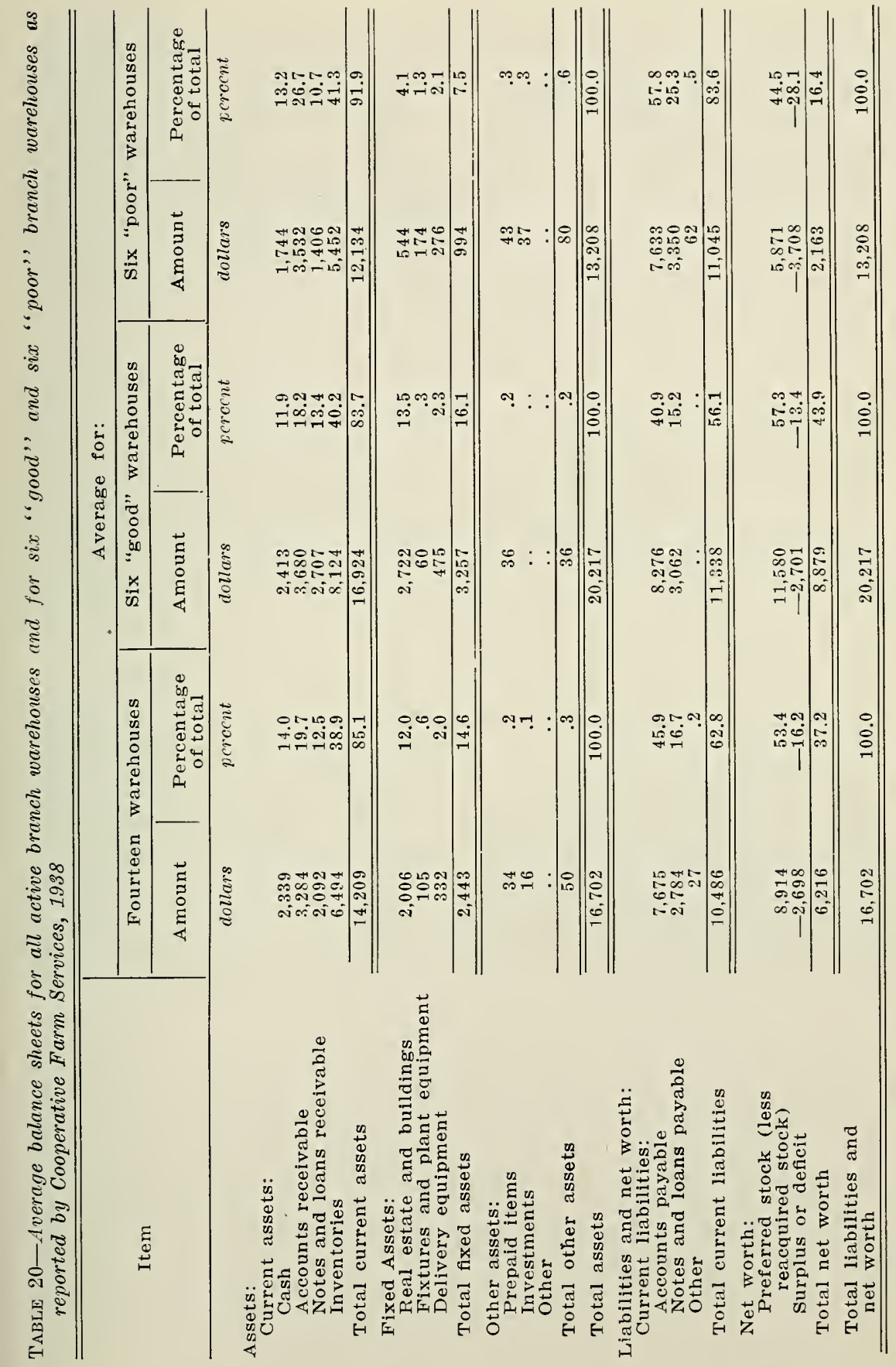




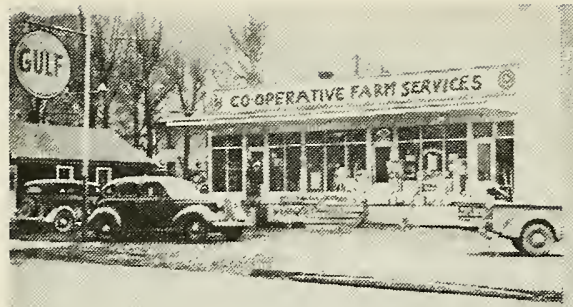

A

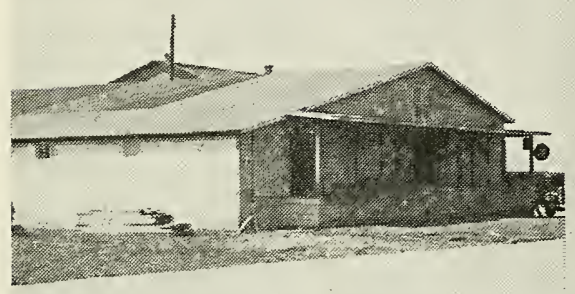

c

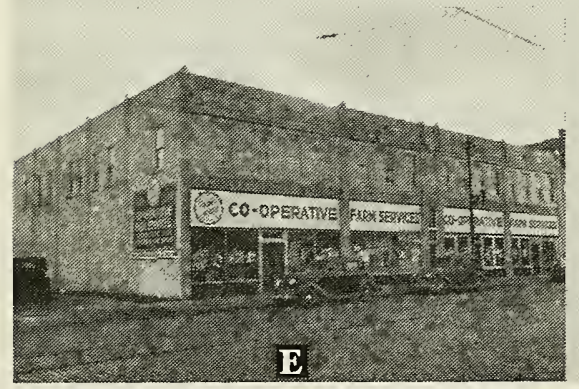

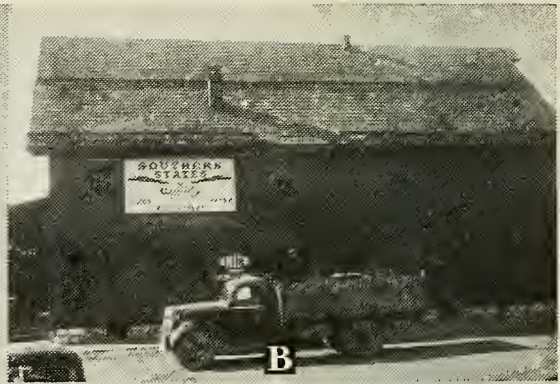

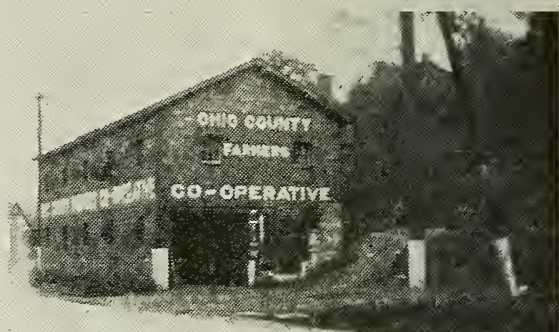

D

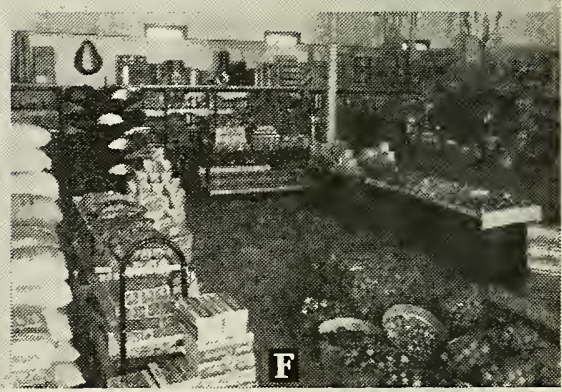

BRANCH WAREHOUSE UNITS OF WHOLESALE FARM-SUPPLY ASSOCIATIONS SERVICING WEST VIRGINIA

A. Location of the branch warehouse at Wellsburg, an establishment built and operated by Cooperative Farm Services. B. Service store operated by Southern States Cooperative, Inc., at Martinsburg. C. Farm-supply warehouse operated at Moorefield - the first cooperative farm-supply warehouse erected in the state. D. Home of the first farm-supply association to incorporate under West Virginia Laws - the Ohio County Farmers Co-operative at Roney's Point, which affiliated with Cooperative Farm Services in 1937. E. Warehouse operated by Cooperative Farm Services at Princeton. F. Interior view of the grocery department of the Princeton warehouse. 
Examination of the financial ratios presented in Table 17 also shows significant differences between the two classes of branch warehouses. Fach ratio presented shows the relative superiority of the good establishments. By way of illustration, receivables per dollar of sales are 40 percent greater for the poor associations, inventories per dollar of sales are 25 percent greater for the same group, and differeness in eurrent, net-worth, and working-capital ratios give further evidence of the less favorable financial condition of the poor warehouses. These data suggest that careful attention to operating and financial practiecs offers possibilities for improving the efficiency of operation to a marked degree.

Average balance sheets were also prepared for branch warehouses classified according to size. Total assets were $\$ 20,106$ for the large warehouses, $\$ 19,806$ for the medium ones, and $\$ 10,450$ for the small ones. Current assets were 78.7 percent 83.9 percent, and 95.7 percent, respectively, for these establishments. The large warehouses were characterized by relatively low amounts of cash, high inventorics, and large investments in real estate (Table 21).

Current liabilities comprised 866 percent of all liabilities and net worth of the large warehouses, but only 42.8 percent and 43.9 percent respectively for the medium and small establishments. Preferred stock made up 34.9 percent, 62.3 percent, and 76.9 percent of all liabilities and net worth items for these types of associations. Data furnished by the warehouse division indicate that credit sales for the period July 1 . 1937 , to July 1, 1938, were reported at 35.4 percent of sales for the large warehouses, 40.8 percent of sales for the medium ones, and 44.5 percent for the small ones. The average turnover of inventories was eight times for large warehouses, seven times for medium ones, and six times for small ones.

\section{Service Store Operations of The Southern States}

Operating costs for 1938 for all branch service stores of Southern States and the two branch service stores of this association operated in West Virginia are shown in Table 22. It will be observed that operating expenses were reported at 6.8 percent of sales for all branch service stores and 6.6 percent for the two service stores operated in West Virginia. All Sonthern States service stores showed a net income of 0.1 cents per dollar of sales while the two stores in West Virginia showed a net income of 0.4 cents per dollar of sales. The relatively low expenditure for such items as wages, truck expense, and office expense help explain why Southern States has been able to keep overhead down and to reduce labor costs per unit.

Although it is impossible to determine the extent to which the operating policies followed by Southern States are responsible for the favorable operating and financial position of its service stores, it is certain that the following factors have been important: (1) supplies are handled on a large volume basis (retail sales were $\$ 2,483,000$ in 1938); (2) volume of business is sufficient to justify owning many of its processing plants; (3) operating and facility loans are obtained from the 


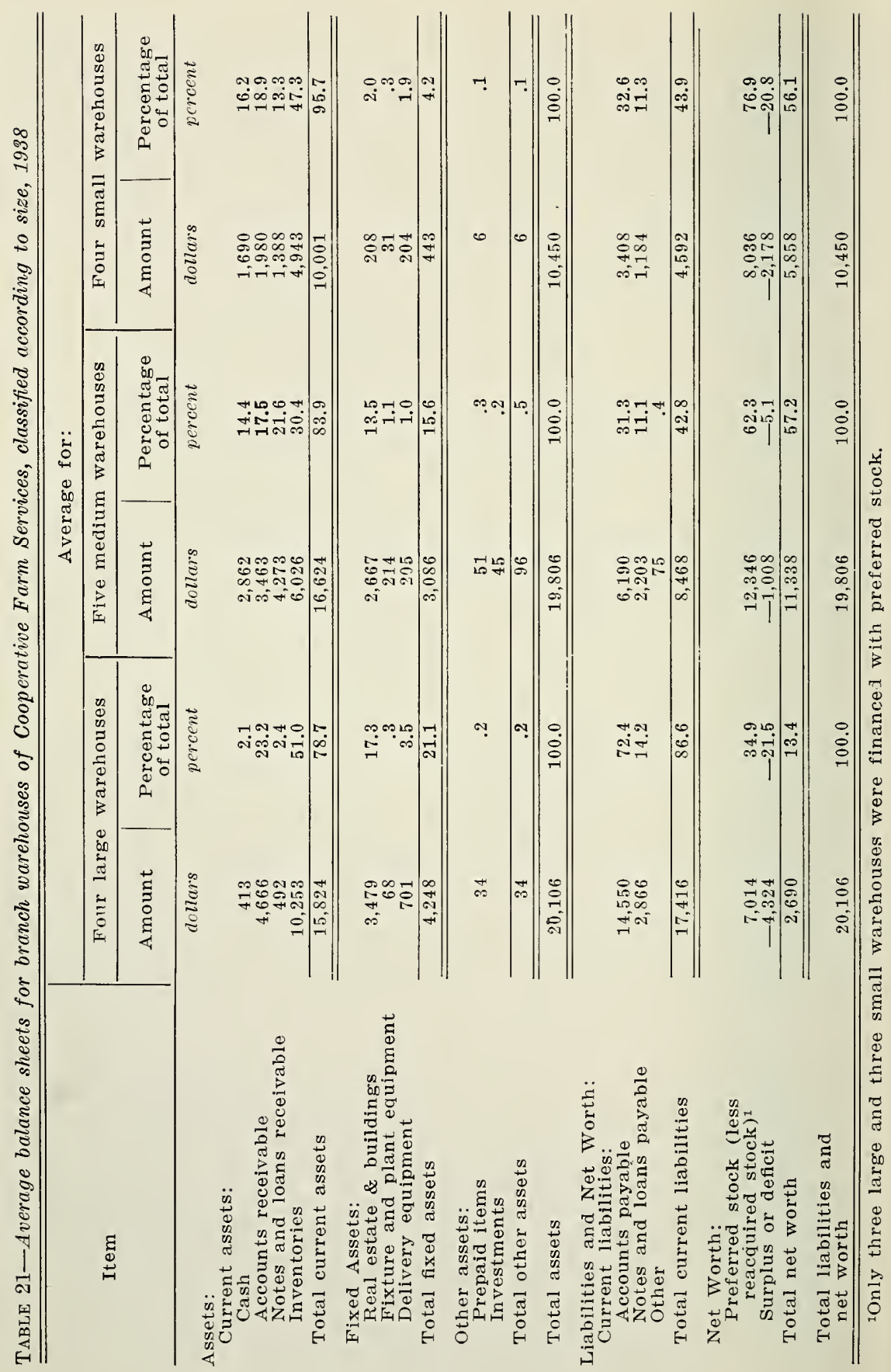


Bank for Cooperatives at relatively low interest rates; $(4)$ average inrentory turnover per year in 1938 was reported at 18 times annual sales; (5) receivables amounted to only 4 percent of sales. These factors suggest that the operating and financial policies followed by Southern States are of such significance that they merit careful investigation by associations handling farm supplies.

TABLE 22-Average operating statements expressed in percentage of total sales of the Southern States service stores, 1938

\begin{tabular}{|c|c|c|}
\hline \multirow{3}{*}{ Item } & \multicolumn{2}{|c|}{ Average for: } \\
\hline & $\begin{array}{l}\text { Thirty-five } \\
\text { Southern States } \\
\text { service stores }\end{array}$ & $\begin{array}{c}\text { Two Southern States } \\
\text { service stores in } \\
\text { West Virginia }\end{array}$ \\
\hline & $\begin{array}{l}\text { Percentage of } \\
\text { total sales }\end{array}$ & $\begin{array}{l}\text { Percentage of } \\
\text { total sales }\end{array}$ \\
\hline $\begin{array}{l}\text { Sales } \\
\text { Less: Cost of sales }\end{array}$ & $\begin{array}{c}\text { percent } \\
100.0 \\
92.4\end{array}$ & $\begin{array}{l}\text { percent } \\
100.0 \\
92.7\end{array}$ \\
\hline Gross Operating income & 7.6 & 7.3 \\
\hline $\begin{array}{l}\text { Operating expenses: } \\
\text { Advertising } \\
\text { Bad accounts } \\
\text { Depreciation } \\
\text { Light and heat } \\
\text { Insurance } \\
\text { Miscellaneous expense } \\
\text { Office expense } \\
\text { Rent } \\
\text { Repairs } \\
\text { Taxes } \\
\text { Telephone and telegraph } \\
\text { Truck expense } \\
\text { Wages, bonuses, and saliries }\end{array}$ & $\begin{array}{c}\ldots{ }^{1} \\
.4 \\
.4 \\
.1 \\
.1 \\
.8 \\
.8 \\
.5 \\
\ldots .{ }^{1} \\
.2 \\
.2 \\
.1 \\
3.2 \\
\end{array}$ & $\begin{array}{r}.1 \\
.2 \\
.1 \\
.1 \\
.1 \\
.7 \\
1.0 \\
.5 \\
\ldots .1 \\
.6 \\
.2 \\
\ldots .1 \\
3.0 \\
\end{array}$ \\
\hline Total operating expenses & 6.8 & 6.6 \\
\hline $\begin{array}{l}\text { Net operating income } \\
\text { Less: other expenses }\end{array}$ & .8 & $\begin{array}{l}.7 \\
.3 \\
\end{array}$ \\
\hline $\begin{array}{l}\text { Total net income } \\
\text { Less: preferred stock dividend }\end{array}$ & $\begin{array}{r}.1 \\
\ldots .\end{array}$ & .4 \\
\hline Balance to surplus & .1 & .4 \\
\hline Average sales per warehouse & $\$ 70,945$ & $\$ 43,788$ \\
\hline
\end{tabular}

ILess than .05 percent.

\section{Some Observations on Local Warehouse Operations}

The foregoing considerations of branch-warehouse operations in West Virginia suggest that the following factors are important in an evaluation of operating performance and financial condition of the branch-warehouse units operated by Cooperative Farm Services.

1. The influence of Cooperative Farm Services would be enhanced if immediate steps were taken to increase the efficiency of its operating yractices and the strength of its financial position. This will necessitate close courdination of accounting procedure in order that a check on the effectiveness of operating practices may be obtained.

2. Differences in the relative operating and financial condition of branch-warehorse establishments serve to emphasize that the Association may find it desirable (a) to set up and apply definite standards of per- 
formance and (b) to investigate carefully the possibilities of and nee! for warehouse services as they apply to each establishment.

3. Large and medium warehouses appear to operate with about equal degrees of efficiency. In other words, expenses per unit of sales do not appear to increase appreciably until annual warehouse sales per unit drop below $\$ 35,000$ to $\$ 40,000$ per year

4. As has been suggested previously, it would be advantageous for the Association to coordinate patronage, ownership of business, and control of operations in the same individuals. This means reorganizing in such a way that patrons become the active members of the Association and are given a voice in policy determination and a financial interest in the Association.

\section{CONCLUSIONS AND RECOMMENDATIONS}

An appraisal of the possibilities and limitations of cooperative purchasing in West Virginia centers around the five factors which also serve as a basis for suggesting needed improvements:

1. The historical, social, and economic background of the rural people of West Virginia has influenced cooperative organization anong farmers in the state and needs to be taken into account in future co. operative plans and practices.

2. Cooperative purchasing, except for the influence of Southern States since 1937, has been largely under the influence of the West Virginia Farm Bureau, a general farm organization.

3. The operating set-up of Cooperative Farm Services has not given the satisfaction desired, and possibilities for improvement have been given consideration.

4. The operating practices followed lend themselves to careful reexamination in order that effective policies may serve as a basis for sound business practices.

5. Imnediate consideration should be given to the operating and financial policies followed.

The remainder of this section will be devoted to amplification of the foregoing factors. It should be remembered that as applying to Cooperative Farm Services these observations relate to operations prior to the carrying out of any of the proposed reorganization changes.

\section{Historical, Social, and Economic Background}

The Historical Bacliground. The oldest active cooperative association in the state was not established until 1915. Between 1916 and 1925 the West Virginia Farm Bureau actively supported cooperative car-door purchasing agencies and local County Farm Bureau Warehouse organizations. In 1925 the State Farm Bureau was instrumental in orgalıizing the West Virginia Farm Bureau Service Company for the purpose of obtaining suppli's on a wholesale basis for local purchasing associ- 
ations. In 1930, Cooperative Farm Services took over the operation of nearly all of the local county Farm Bureau warehouses in the state.

It is evident that, historically, cooperative purchasing is a relatively new development in West Virginia. Although it is not possible to determine to what degree this situation is traceable to the status of agricultural development or to the absence of trained leaders, it is certain that both factors are responsible in some degree for the present status of cooperative development.

The Social Background. While social relationships are largely intangible and consequently do not lend themselves to definite measurement, there is no doubt that they have had and will continue to have a marked influence on the development of cooperation in the state. For example: (1) West Virginia agriculture presents a strange mixture of self-sufficient and independent mountaineer farmers on one extreme as contrasted on the other with the highly commercialized agriculture of "valley" farmers who still possess numerable traits dating back to the plantation era; (2) the independent, individualistic, and cautious characteristics of the former are in sharp contrast with the friendly, sociable, and easy-going traits of the latter; (3) in many sections of the state such factors as strong and emotional political feelings, distinct religious sectarianism, relatively low educational standards and attainments, and the power of deep-rooted customs and ideas are all factors requiring careful consideration in appraising the development of and the possibilities for cooperative purchasing.

The Economic Background. The limited possibilities for agricultural development in the state mean that neither cooperative purchasing nol cooperative marketing will attain the prominence it has in many other sections of the country. By way of illustration, the economic development of agriculture in the state indicates that: (1) with respect to land use, while two-thirds of the land in the state is in farms, only one-fourth of the farm land is in crops-chiefly hay and corn-one-half is in pasture, and the remainder is devoted to other uses; (2) between two-thirds and three-fourths of both the gross and the cash agricultural income is derived from livestock and livestock products which, when considered in conjunction with the prevailing land-use pattern gives some indication of the relative importance of livestock enterprises and serves to suggest that feed, seed, lime, and fertilizers are the types of supplies most commonly purchased hy farmers; (3) although wide variation exists in the prevailing types of farming, about two-thirds of all farms are classified as self-sufficing or part-time, and the resulting low incomes, combined with small holdings, mean limited expenditure even for the more important farm supplies; (4) cooperative marketing in the state has developed primarily along the lines of dairy, livestock, wool, and fruit associations, and the proportion of all agricultural products that are marketed through cooperative channels amounts to somewhere between 6 and 8 percent of the total farm sales; (5) cooperative purchasing has developed along the lines of feed, seed, and fertilizer distribution. and the proportion of these supplies purchased through cooperative as- 
sociations accounts for between 5 to 10 percent of all farm supplies purchased.

In general, economic developments indicate that with respect to the operation of cooperative purchasing associations in the state: (a) credit risks are likely to be unavoidably high; (b) even under conditions of the most efficient operation, the apparent advantages of cooperative purchasing will be fewer and less striking than in regions of more intensive farming; (c) costs of operation, of necessity, will be relatively high; and (d) the heterogeneity of farming practices and operations results in wide variety of agricultural interests and serves to limit effective cooperative endeavor. These difficulties are inherent, however, in any distributive system-private or cooperative-and to the extent that economic need exists for cooperative purchasing associations, they may be of appreciable importance in West Virginia, even though the scope of operation is limited.

\section{The Advisability of Separating Business Control of the Cooperative Farm Services from the West Virginia Farm Bureau}

Experience has shown that it is usually a good policy to separate completely cooperative business operations from activities of general farm organizations. In this connection, it would be well for Cooperative Farm Services to consider the experience of other cooperative associations. Virtual control of Cooperative Farm Services by the Farm Bureau has meant that: (1) control of cooperative purchasing in West Virginia has been vested largely in the hands of farmers other than patrons, (2) special favors have been demanded by and granted to Farm Bureau members in the purchasing of farm supplies, and (3) a distinct cleavage has developed between patronage, membership, and ownership of farm-supply associations. At best, general farm organizations are subject to political pressure from within and without. For a business organization to be dependent upon a general farm organization is usually a risky business policy. Better and more permanent results, even though sometimes slower, usually are secured when cooperative associations base their claim to existence on performance as measured by quality of goods handled, by prices charged, and by services rendered.

\section{Operating Set-Up of Cooperative Farm Services}

Membership. Membership in Cooperative Farm Services is held by 22 general county Farm Bureaus and by four marketing organizations. There are also branch warehouses in two counties in which general county Farm Bureaus own no common stock in Cooperative Farm Services. Consequently they hold no membership in the Association. On the other hand, eleven general county Farm Bureaus own common stock in Cooperative Farn Services even though there are no branch warehouses in these counties. In addition the Association reports dealing with county Farm Bureaus in nine counties and with independent dealers in eight other counties in which county Farm Bureaus do not own common stock and have no voice in the operation of the affairs of Cooperative Farm 
Services. These arrangements do not enable patrons to have an active voice in the affairs of the Association.

However, even if every county Farm Bureau in counties in which Cooperative Farm Services has branch warehouses or has developed distributive outlets through county Farm Bureaus or through private dealers, had a voice in the affairs of the Association, the proportion of patrons represented even indirectly would be small. Data supplied by managers of seven branch warehouses suggest that the Association would find defiinite advantages in reorganizing in such a way that active patrons become participating members. Such reorganization would enable the Association to operate in accordance with cooperative principles and enhance the prospect of attaining membership loyalty of more than the "fair weather variety".

Cooperative Farm Services also might consider means of improving membership relations through education. Such a program might well include provisions for: (1) holding at least one annual meeting for patrons designed to acquaint them with operating, financial, and merchandising policies; (2) establishment of a house organ; and (3) establishing a definite policy of training patrons for participation in affairs of the Association.

Organization. The organization of Cooperative Farm Services offers very definite possibilities for improvement. The following alternatives suggest themselves: (1) continuation of the present structure giving careful consideration to possibilities for improvement; (2) decentralization and purchase of supplies for locally incorporated county associations federated with Cooperative Farm Services, or (3) combination of some of the more workable features of each plan.

Irrespective of the type of organization adopted, it is important that the following considerations be kept in mind with respect to problems of organization: (1) associating patronage, ounership, and management and control of the Association in the same individuals. This means that patrons of an association should be given the opportunity both to express themselves in business affairs and to shoulder the responsibilities connected with operation. (2) Giving careful attention to such operating items as credit control, accounting procedure, purchasing methods, sales practices, and delivery policy. (3) Calling of preferred stock and adopting a financial program having provisions for keeping the financial interest of members in the hands of active patrons. Organization along these lines would do much to make patrons realize that either success or failure of the Association will have a definite bearing on the quality of farm supplies they are able to obtain, the services that are available, and the safety of their investment in the Association.

Management and Control. As indicated, management and control of Cooperative Farm Services is vested in a board of nine directors who are elected from among representatives of the associations owning common stock in Cooperative Farm Services. This arrangement does not permit direct patronage participation and means that patrons or their supply agencies do not necessarily constitute the active membership of the Association. 
Irrespective of whether the branch-warehouse type of organization is maintained or whether incorporated warehouses are established, the patrons through their distributive agency or by direct vote should elect the directors for Cooperative Farm Services. This means that control of the central association should be on the basis either of distributive agencies or of direct patronage. The proposed plan of reorganization, by granting local warehouse associations one vote in Cooperative Farm Services, should help bring about more direct control by patrons.

Cooperative associations in West Virginia need to give careful attention to the training of warehouse managers. Managers of many of the branch warehouses have had little experience and possess few qualifications that enable them to give the type of service that patrons have a right to expect from a cooperative association. These difficulties could be remedied in part by: (1) giving careful consideration to the qualifications and training of prospective warehouse operators; (2) developing warehouse operators from the ranks--that is, training them as apprentices of the hetter warehouse managers; and (3) holding cooperative training schools yearly for managers, members of advisory committees or boards of directors, and cooperative leaders. These practices would be helpful in acquainting these groups with the possibilities and functions of cooperative associations, the responsibilities of cooperative leaders, and the opportunities for service that exist in warehouse operations. Such schools might well draw on cooperative leaders of successful purchasing associations, the College of Agriculture, and the Farm Credit Administration.

Should Cooperative Farm Services continue operations on a branch warehouse basis, it is believed that active advisory committees should be made a functional part of the Association. Even if branch warehouses are to be reorganized as local associations, it might be well for local advisory committees to acquaint themselves with the many problems of warehouse operation before complete reorganization takes place. The aim should be to have these committees operate as much as possible like a board of directors of an incorporated warehouse. Instead of being appointed by the president of the local county Farm Bureau, advisory committees should be elected by patrons of the local warehouses. Such a board if properly directed by the Association can render valuable service in bringing about a closer relationship between the patrons of the local establishment and the Association. It also could assist in acquainting local patrons with the practices and policies of the central organization and in acquainting the central Association with needs and desires of local patrons.

Side line Enterprises. Certain possibilities with respect to the expansion of business activities in some of the self-sufficing areas exist in the handling of various side line enterprises-notably eggs, grain, hay, country-cured hams, and cream. To the extent that such side line activities are engaged in, however, it is important that: (1) managers of warehouses be able to handle such activities without interfering with the purchasing phase of the business; (2) managers be well versed with the 
various problems involved in handling these products; and (3) a definite accounting procedure be set up to indicate the extent and returns from these undertakings. Any attempts to combine cooperative purchasing with marketing activities or with new developments such as refrigerated food lockers should not be attempted until purchasing activities have been established on a sound basis.

\section{Operating Practices}

Purchasing Policy. Cooperative Farm Services is in a position to improve the purchasing policy it has followed. Examination of the inventory item indicates that the warehouse division of the Association averages no more than seven turnovers a year. This would suggest that careful consideration might well be given to the elimination of unprofitable, slow-moving, and non-essential supplies.

The purchasing policy of the Association might be more closely coordinated with its accounting department if steps were taken to: (1) determine the gross income obtained on the various commodities handled; (2) investigate possibilities of increasing the distribution of fast-moving farm supplies; (3) eliminate slow-moving items, either by discontinuing certain lines entirely or by furnishing the quality of goods desired; and (4) give additional attention to the possibilities of obtaining advance orders from distributive agencies.

Sales Policy. The purchasing division has developed outlets through branch warehonses, county Farm Bureaus, and independent dealers. No basis exists, however, for evaluating the completeness, the effectiveness, and the efficiency with which farmers are serviced through these agencies. It would be helpful if steps were taken to set up financial and operating data in such a way that guideposts may be established which will show the type and nature of sales made, the costs of making such sales, and general trends in sales practices.

While definite peaks in business activity occur in the spring and fall, there likewise are dull seasons during midsummer and midwinter. At present feed, seed, and fertilizer constitute the main items of business. The Association might give attention to the development of non-seasonal business along such lines as building materials, paints, cement and lime, various petroleum products, and similar supplies.

The Association has increased the effectiveness of eredit control over that of the formerly local incorporated associations. Two branch warehouses operate on practically a cash basis. There is a general rule that credit should be limited to 30 days. The practice of deducting older accounts from the salary of warehouse managers is followed at times. In other instances the Association requests that a credit statement be furnished. If the various receivable items were analyzed according to age, the Association would be in position to establish more effective credit control.

The Association has recently adopted the policy of making delivery charges which vary with distance and with volume of product purchased. Further service might be given to patrons in the form of special prices for various products if purchased at the car door. 
The purchasing division follows the practice of granting a patronage dividend on fertilizer sales. Since this division operates primarily on a commission basis, it has no long-time obligations and should be in position to refund the greater part of its accumulations to patrons rather than build up a surplus on all business operations. When patronage dividends are granted, Cooperative Farm Services might strengthen its ties with local patrons by providing that dividends be granted directly to patrons rather than applied to the accounts of branch warehouses. Such a practice would strengthen the local ties of the Association and improve membership morale. However, when local warehouse associations are established, dividends should be granted directly to such organizations.

\section{Financial Policies}

Since the purchasing division of Cooperative Farm Services operates largely on a commission basis, the financial problems of the Association to a large extent center about the operation of the warehouse division. The warehouse division is financed almost entirely with preferred stock. In addition to being extremely costly, the present practice of financing through cumulative preferred stock has failed to develop financial responsibility among patrons and members and has proved detrimental to the development of sound membership and management relations. Interest charges on preferred stock have approximated $\$ 8,500$ per year during the past five years. This amounts to 1.5 percent of sales, 10 to 12 percent of the total operating expenses of the warehouse division, or 8 to 11 percent of the consolidated operating expenses of the Association.

Steps for improvement of the Association's financial position might include: (1) making an attempt to refinance by remodeling the organization and operating set-up of the Association so as to be able to qualify for loans from the Bank for Cooperatives; (2) calling all preferred stock; (3) establishing financial responsibility among patrons by providing for eventually meeting future financial needs out of funds secured directly from patrons of the Association; and (4) coordinating the financial policy of the Association with sound accounting policy to the end that the effectiveness of the various operating practices and policies followed can be checked.

In general, this study indicates that Cooperative Farm Services would improve its status as a farm supply association by giving immediate attention to the following factors: (1) reorganization in order to associate membership, management, and ounership with the same individuals; such reorganization may be effected through either (a) remodeling the basis of organization for the maintenance of branch warehouse units or (b) setting up local warehouse associations on a federated basis; (2) calling preferred stock and providing for the establishment of a permanent financial policy designed to obtain operating funds primarily from member patrons; (3) establishing purchasing and sales policies designed to meet the specific needs of farmers and to serve as the basis for sound operating practices; and (4) revising the existing accounting and auditing procedure in order that "measuring-sticks" may be set up to check efficiency and evaluate performance. 


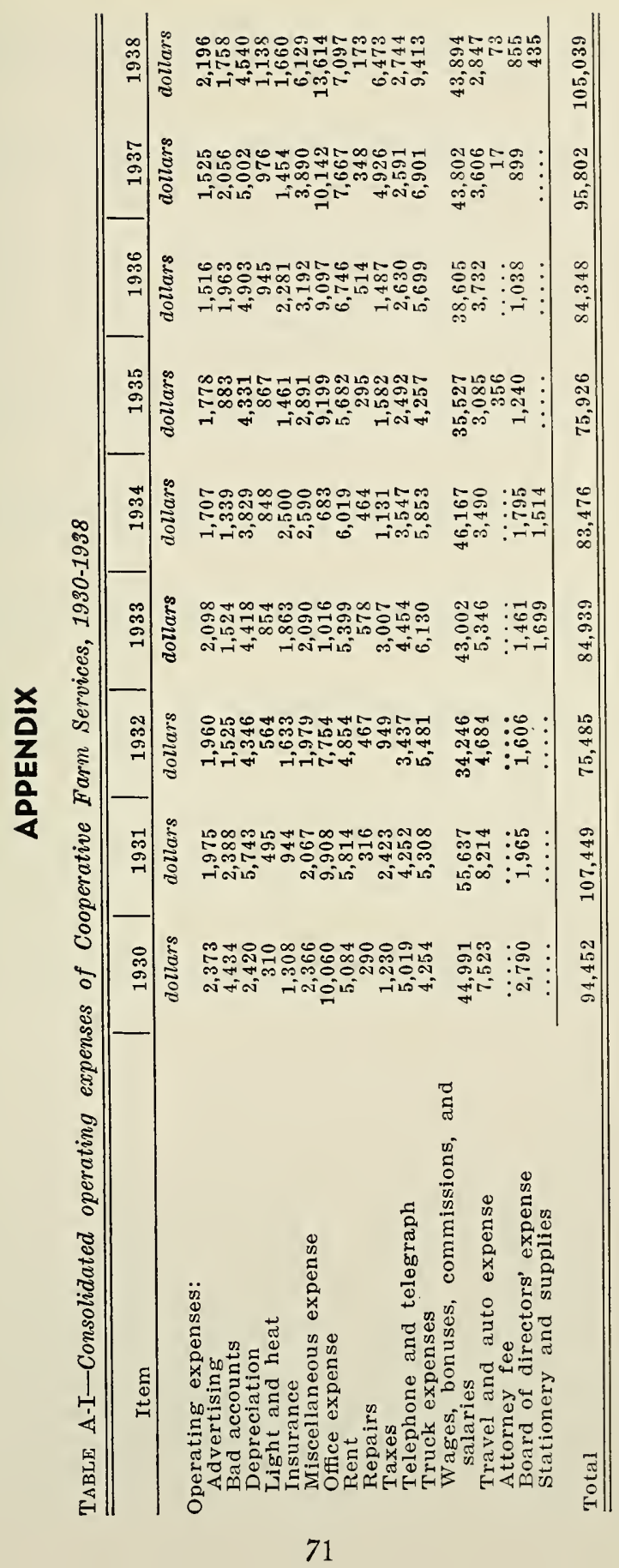




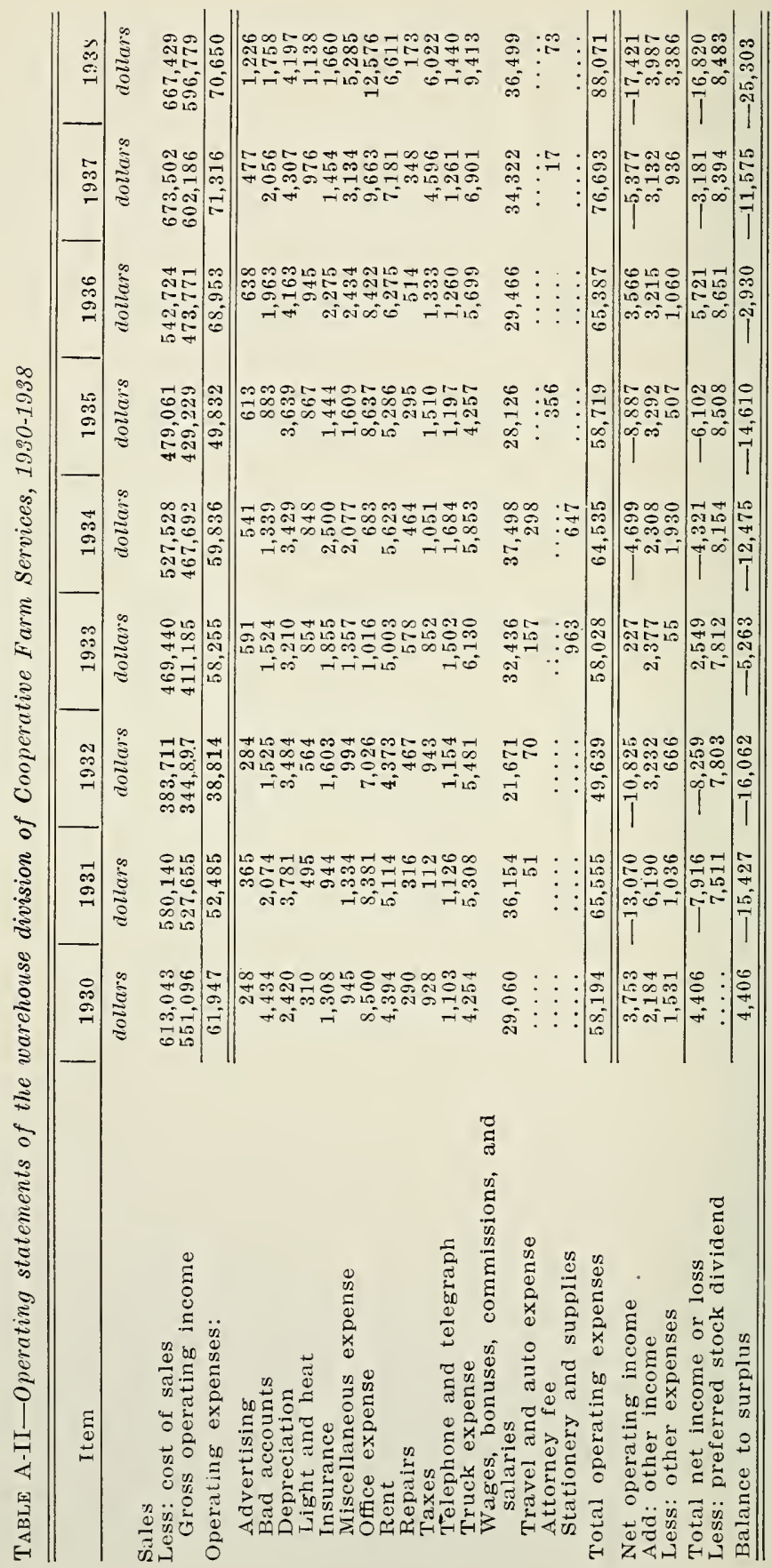




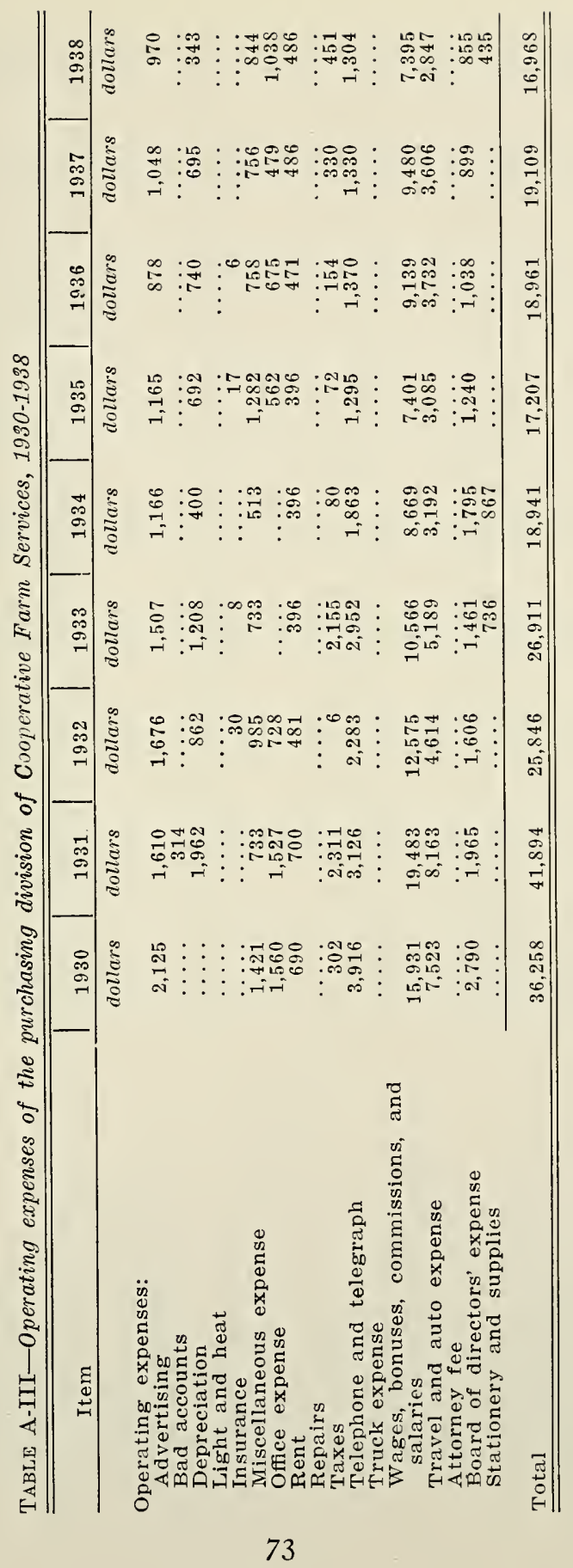




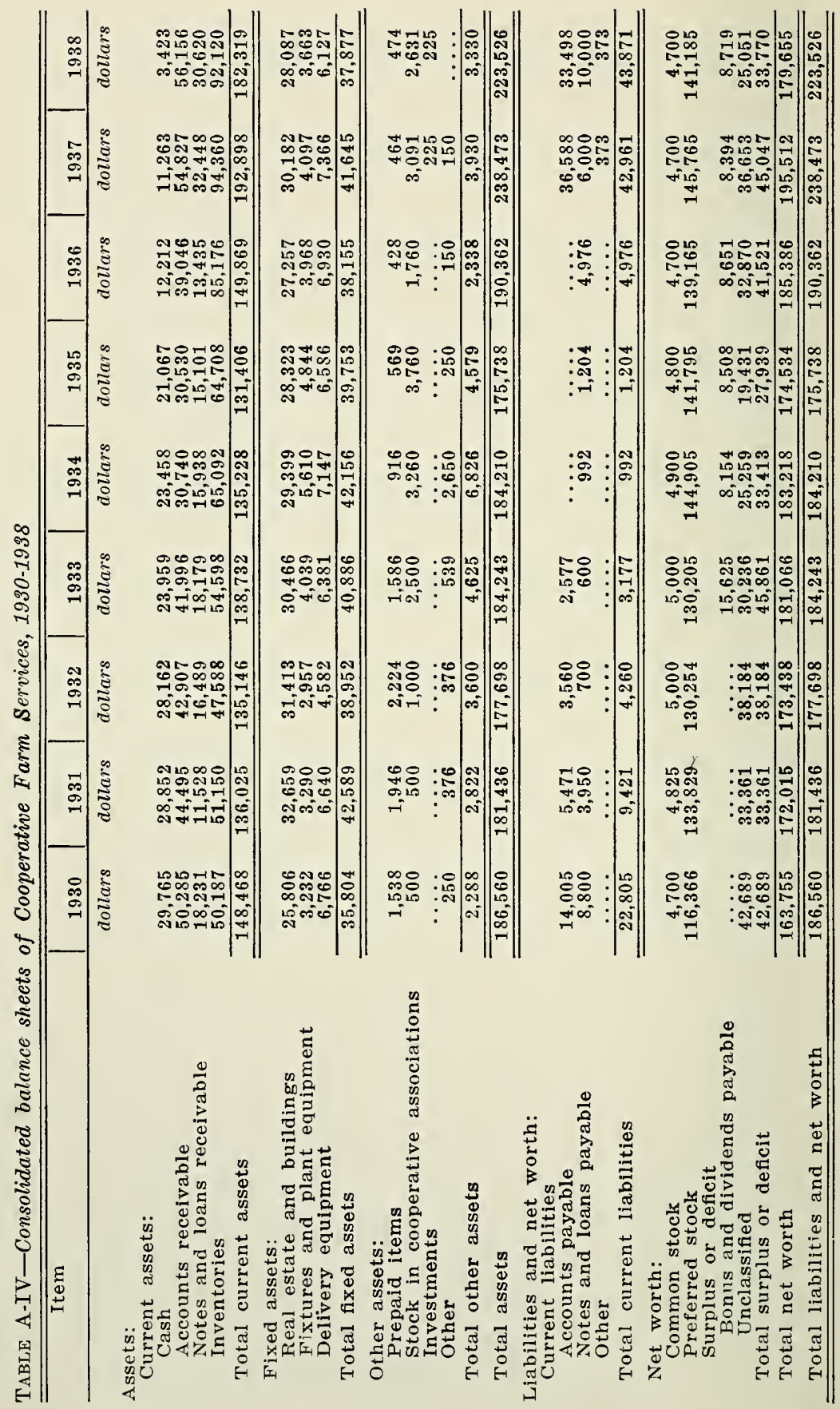




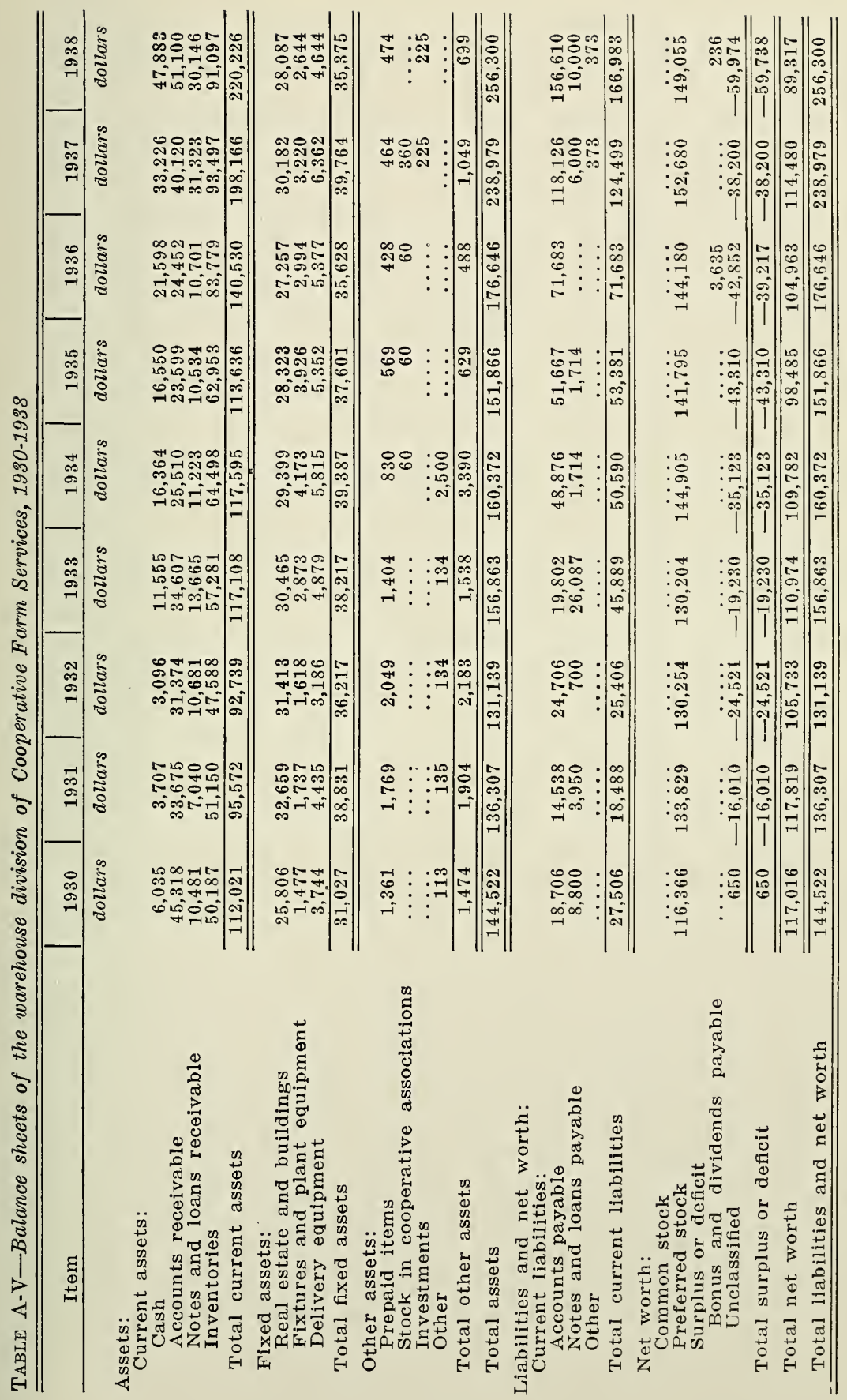




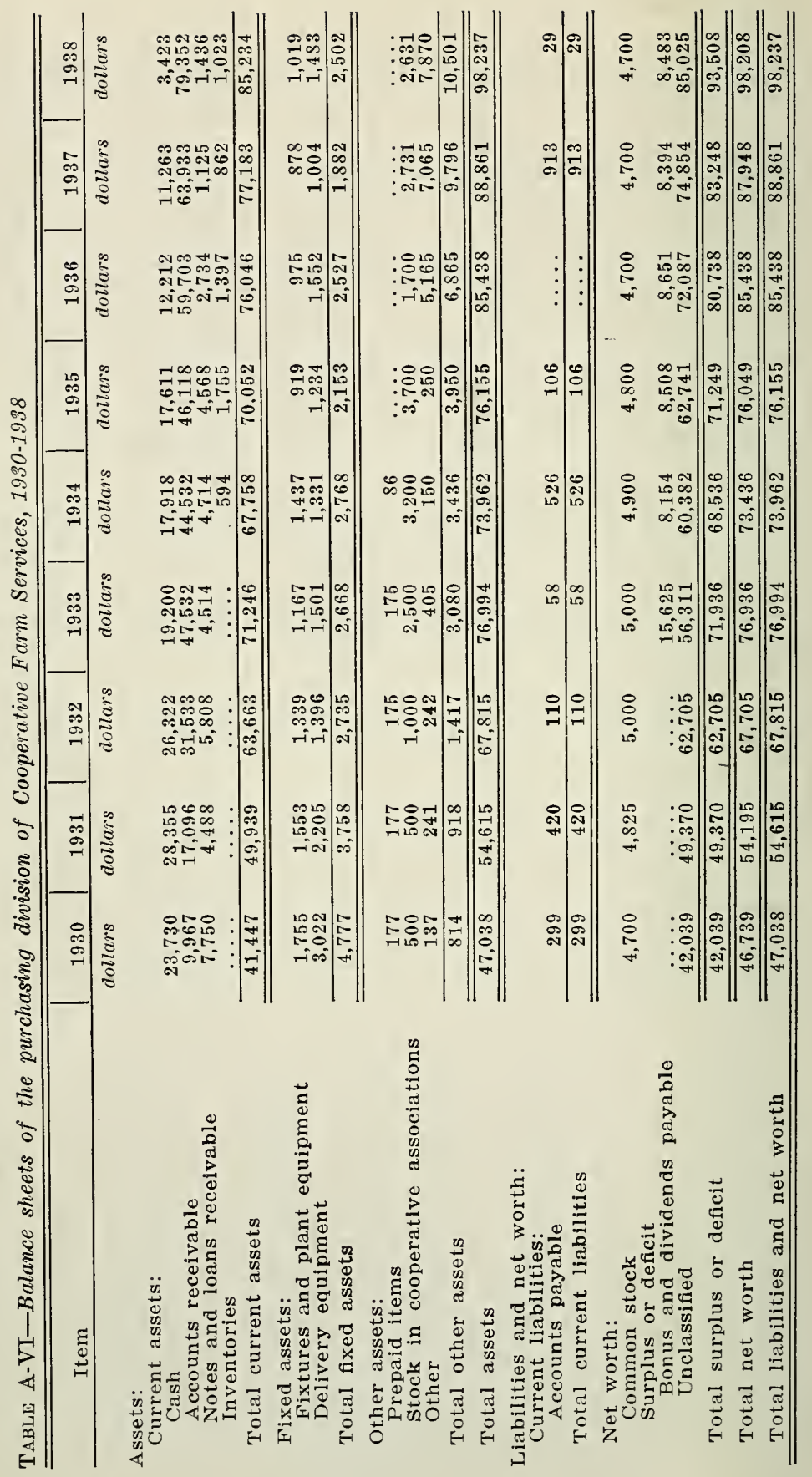


$\frac{100}{20}$ 